TEXT Vol 19 Special Issue No 29 (April 2015)

Scriptwriting as Creative Writing Research II

\title{
Contents
}

- Dallas John Baker, Bedside manners page 2

- Craig Batty, Dirty talk: scriptwriting, script editing and the creative process page 19

- Debra Beattie, John and Jennie page 36

- Susan Davis, Questions for George page 51

- Kath Dooley, Night bus page 67

- Anne Harris, Lola in the bathtub page 81

- Linda Hassall, Motel chronicles page 107

- Stephen Sculley, Stringer episode 1: A television novel page 121

- Stayci Taylor, Mounting the Men's film festival: a mockumentary web series.

Webisode 1: Power cut page 151

- $\quad$ Temenuga Trifonova, Man of glass page 166

- Linden Wilkinson and Michael Anderson, Artistry \& academia: adventures on the other side of orthodoxy page 200 


\title{
University of Southern Queensland
}

\author{
Dallas John Baker
}

\section{Bedside manners}

\begin{abstract}
:
This work is a creative exploration of notions of masculinity and male sexuality. Specifically, it explores the idea that male sexuality and gender exist on a continuum and defy simple categorization. The script was developed using an interdisciplinary approach including traditional research into theories of gender and sexuality and fiction writing techniques such as associative and stream-of-consciousness composition. In this way, a script was produced that indirectly refers to the notion of fluid sexuality whilst telling a dramatic story about two men who occupy very different places on the gender and sexuality spectrum.
\end{abstract}

\section{Biographical note:}

Dr Dallas J Baker is an academic in the School of Arts and Communication at University of Southern Queensland. His study and research intersect with a number of disciplines: writing, editing and publishing, and media and cultural studies. Dallas is also a writer with creative work published in a number of journals and anthologies. His current research interests are memoir and memory, scriptwriting, editing and publishing and 'self-making' in cultural practices such as creative writing and popular music consumption.

Keywords:

Creative writing - Scriptwriting as research - LGBTIQ drama 


\section{Bedside manners}

\section{The Characters}

REED WALKER - An effeminate man in his mid-thirties. The focus of a lot of abuse in his conservative hometown of Toowoomba.

DAN BAXTER - A good-looking, rough and tumble guy in his mid-twenties who has, in the past, tormented Reed.

SIMON DONCASTER - A local redneck in his mid-twenties.

MAL MCNAIR - Another local redneck, also in his mid-twenties.

\section{Setting}

The action takes place in the autumn of 1982 in Toowoomba, Queensland, a conservative town with tree-lined streets and many old, heritage value homes.

Toowoomba is known for its many parks and gardens, as well as its annual Carnival of Flowers, but Toowoomba has a dark side as well, in that it has a history of intolerance and violence.

\section{Locations}

Campbell Street - a leafy tree-lined street in Toowoomba featuring rows of weatherboard houses typical of Queensland, with verandas, galvanized iron roofing and redbrick chimneys.

Workers Cottage - A small weatherboard Queenslander, sparsely furnished. This is Dan Baxter's place.

Old Queenslander - a large, slightly run-down weatherboard home with wrap-around verandas in a large, almost overgrown, yard. The interior is decorated in a heady mix of Asian styles popular in the late Victorian era. The bedroom is fussily decorated with an eclectic array of Victoriana and many knick-knacks of Oriental origin. 


\section{SCENE 1}

\section{EXT. A TOOWOOMBA STREET - DAY}

From above, we see a quiet tree-lined street. On both sides of the street are weatherboard houses, all with corrugated iron roofs and redbrick chimneys. This is Campbell street, Toowoomba .

On a footpath that threads its way in and out of tree-shade, a solitary figure walks away from the camera.

From behind, the figure looks like some flamboyant actress, but dressed in a manly fashion. The person wears a welltailored suit, pants and jacket which, despite its masculine cut, gives an overall impression of femininity. This is REED WALKER.

CUT TO:

2. EXT. TOOWOOMBA STREET - DAY

REED's face is angular and refined. His skin is smooth and pale. He is in his mid-thirties. He wears a lurid red neckkerchief with an oriental design. He carries himself with a kind of rebellious and resolute dignity.

CUT TO:

\section{EXT. TOOWOOMBA STREET - DAY, CONTINUOUS}

REED looks up from tidying his kerchief and sees ahead three shirtless young men coming around a corner towards him.

The men are handsome in a redneck way; well-built but wearing dirty, faded work pants. It is a hot, sweaty day and their shirts are tied around their waists. Their names are SIMON DONCASTER, MAL MCNAIR and DAN BAXTER - three local toughs.

As soon as Reed sees them, he takes a pair of round sunglasses out of his breast pocket and puts them on, straightening his hair at the same time - in an act of vanity, pride ... and anxiety.

The young men see Reed. Simon thumps Mal in the arm and smirks - preliminary signals to the ridicule he intends to throw at Reed. Dan Baxter hangs back a bit. 
As the three men get nearer, Reed steels himself for the inevitable.

SIMON DONCASTER

Hey Reed! How are ya this mornin'

darlin'?

MAL MCNAIR

Out for a morning stroll, petal?

Reed ignores them, lifts his head a little higher, and walks past. The shirtless men stop.

SIMON DONCASTER

Hey Reed, how about a bit of this!

Simon grabs his crotch whilst Mal, spurred on by his friend, starts to rub his own nipple.

\author{
MAL MCNAIR \\ How about it Reed! Wanna try some?
}

The two rednecks laugh, while Dan Baxter, still standing back from his friends, looks a little uncomfortable.

Reed is not foolish enough to stop, but he can't help but mutter a retort:

\title{
REED
}

Just lovely. You boys are so cute I cannot find words to express...

Simon Doncaster suddenly jumps forward and shoves Reed, who nearly falls down. Dan Baxter steps forward and grabs hold of Simon's shoulder to restrain him. Simon gives Dan a look of disgust and throws him off. Dan staggers back a few paces, then Simon turns his attention back to Reed:

\section{SIMON DONCASTER}

You love words like 'lovely' and 'cute', don't you Reed? Yeah, you love words like that, poofter words.

The word 'poofter' resonates harshly. Reed is visibly disturbed. He turns and continues down the street away from them, trembling. Simon is about to continue his abuse but is stopped when, out of the blue, something strikes him on the head. 


\author{
(to Dan) \\ SIMON DONCASTER \\ Jesus! What did you do that for?!
}

He holds his head where a projectile struck.

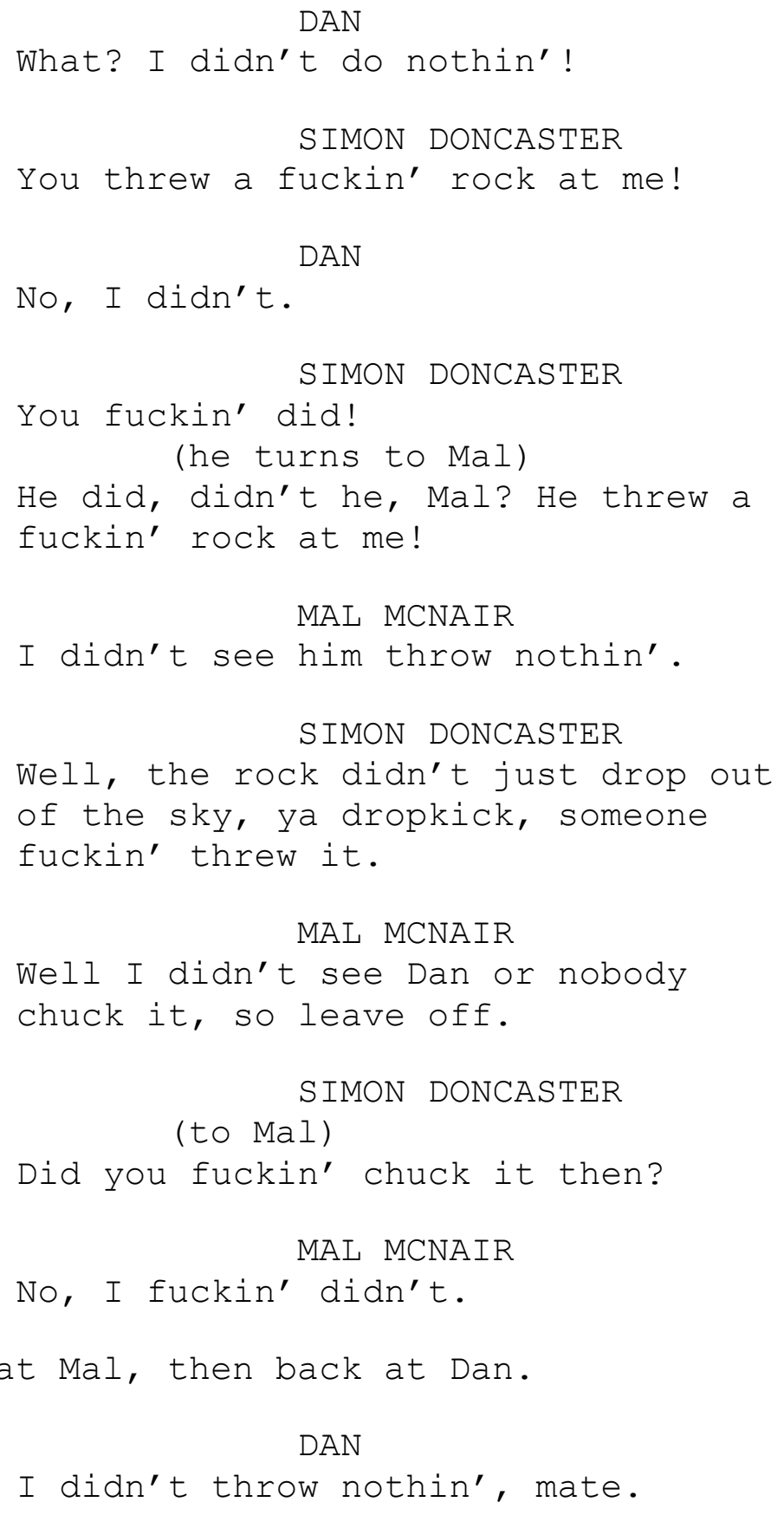

Mal shrugs and stalks off down the road, in the opposite direction to Reed.

Simon glares at Dan one more time but then follows Mal, grumbling under his breath and rubbing his head. Dan is left standing on the footpath, he turns to watch Reed hurrying away . 
Reed glances back, more interested in making sure he isn't being followed than finding out what's happening, but he sees that the three guys are not pursuing him. He sighs with relief.

A moment later, Reed turns a corner. He is safe. He takes off his sunglasses and puts them back in his breast pocket.

CUT TO:

4. EXT. TOOWOOMBA STREET - DAY, CONTINUOUS

DAN turns to follow his friends, who have renewed their argument about who threw the rock. As he walks away, he drops something from his clenched hand.

The camera zooms in on the object: it is another rock.

Dan smirks and proceeds down the street.

CUT TO:

\section{SCENE 2}

5. EXT. SMALL WORKERS' COTTAGE, ESTABLISHING - THAT NIGHT

A well-kept workers' cottage sits in a shadowy street beneath a clear sky. Light from one window spills out into the front yard and illuminates a gnarled tree.

CUT TO:

6. INT. SMALL WORKERS' COTTAGE, BEDROOM - SAME NIGHT

A sparsely furnished, tidy and notably unadorned bedroom is lit by the yellowish light of a single electric light overhead.

DAN BAXTER lies on a single bed dressed only in his underwear. He stares up at the ceiling and chews on his bottom lip as if trying to make a decision.

A towel is draped over a wooden chair beside the bed. To one side of the bed, a door is ajar through which we can see a slightly steamy bathroom, where another electric light glows warmly above an old tub. 
Dan suddenly gets up off the bed, looking determined, and grabs a pair of jeans that are folded on the seat of the chair and pulls them on. He then grabs a short-sleeved shirt hanging on the bathroom doorknob and pulls that on. Before buttoning up the shirt, he finds his boots and sits down to put them on as well. Before putting on the boots, he seems to change his mind.

He jumps up off the bed again and takes off the shirt and hangs it back on the doorknob. He pulls off the jeans and sits back down on the bed in his underwear, holding his face in his hands, clearly tormented by indecision. He slumps back on the bed and stares at the ceiling, chewing on his bottom lip again.

After a moment he gets up once more and pulls on his jeans again. He grabs his socks and boots and puts them on. Then he grabs the short sleeve shirt off the doorknob and puts that on. As he's buttoning it up, he looks at it and picks at one of the buttons, seeming dissatisfied with it. He takes the shirt off again and walks over to a wardrobe. He takes out of the wardrobe a pristine white long-sleeved shirt that looks very neatly pressed. He puts that on, rolls up the sleeves a little and then buttons it up. He pauses a moment, chewing on his lip. Then, with a sigh of resignation he turns off the bathroom light and walks out of the bedroom.

CUT TO:

\section{EXT. OLD QUEENSLANDER - SAME NIGHT, ESTABLISHING}

An old Queenslander with a wrap-around veranda is crossed by the shadow of a single cloud. The place looks unkempt yet somehow appealing. This is REED WALKER's house.

The night breeze causes trees in the large yard to sway and leaves to drift across the ground, as if stalking the cloud above.

CUT TO:

\section{INT. REED'S HOUSE, BEDROOM - NIGHT}

In REED's bedroom, strips of moonlight shine in between the curtain folds, illuminating an assemblage of Victoriana and oriental knick-knacks, giving a somewhat eerie appearance to the room.

In a large brass bed, the figure of a sleeping Reed is just discernable in the dim light. 


\section{EXT. REED'S HOUSE - NIGHT, CONTINUOUS}

Outside REED's house, someone is letting themselves in through an unlocked window. The intruder climbs in and makes their way down the hall. By their outline, we can see that it is a man.

\section{CUT TO:}

\section{INT. REED'S HOUSE, BEDROOM - NIGHT, CONTINUOUS}

REED is sound asleep, totally unaware that someone has broken into his house.

The intruder quietly opens Reed's bedroom door and enters. The sound of the door opening causes REED to shift a little in his bed but he does not wake.

The intruder reaches the bed, his shadow falling over Reed's face, and places a large hand over Reed's mouth.

Reed wakes and attempts to scream out for help, he can't - the intruder's hand muffles the sound.

While Reed struggles, the intruder sits down on the bed - his face enters the moonlight.

It is DAN BAXTER. He is wearing dark blue jeans and a loosely buttoned but pristinely white long-sleeved shirt.

\section{DAN}

Shush will ya, shush. I'm not goin'

to hurt ya.

Reed stops struggling. Dan takes his hand away from REED's mouth.

\section{REED}

Dan Baxter! What are you doing, climbing in my window and manhandling me like that! Have you no manners? I should slap you silly!

\section{DAN}

I should be slapping you! Prancing around town gettin' everyone all

ticked off. 


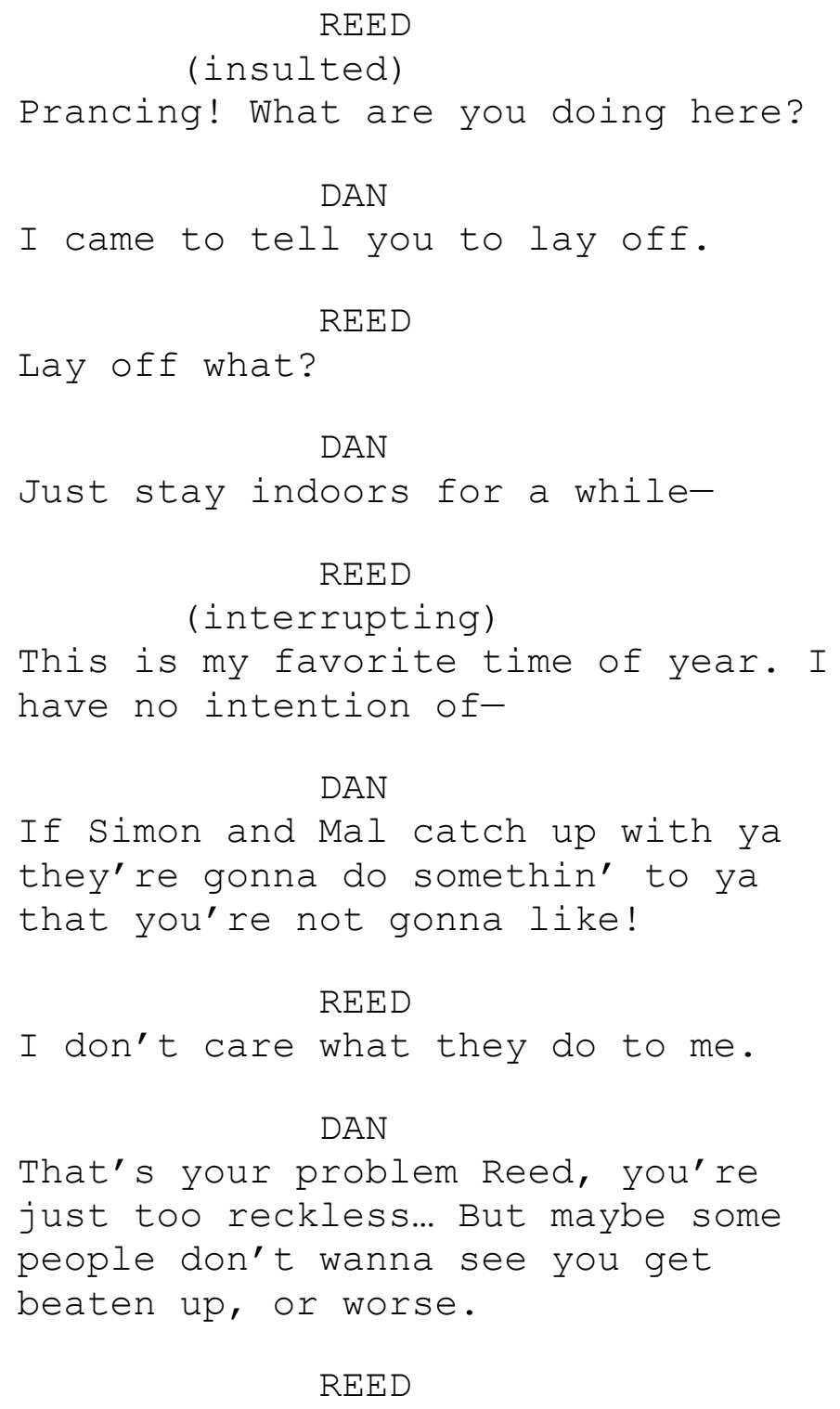

Like who?

DAN

Like me maybe...

\section{REED}

Well, you certainly have turned around. It seems only this morning you were tormenting me on Campbell Street.

DAN

I was just goin' along with my mates. A bloke's gotta go along with his mates. It's like a rule.

REED

That is a very dumb rule. 
DAN

Maybe... I just wanted to warn you that Simon an' Mal have bees in

their bonnets-

REED

The things people do for fashion...

Dan stands up with a sudden outburst of emotion.

DAN

Can't you be serious! They might really hurt you this time! Don't you know what blokes like them do to fellas like you in this town?

REED

Of course I do. You forget I've lived here all my life. I've heard all the stories: young men found bashed to death in Queens Park. Girly little boys whose own fathers tie them in potato sacks and drown them in Cooby Dam. But they're just stories to scare people like me, and I refuse to be scared.

\section{DAN}

Some of those aren't just stories. You don't know what people like Simon are capable of. He really hates... Well, he really hates-

\section{REED}

Hates what? Faggots? Poofters?

\section{DAN}

I've never used them words on you

Reed, you know I haven't. But, yeah, he hates poofters, really hates 'em. He's mental about it... you've got to be careful Reed.

Reed looks surprised at Dan's concern. 
REED

Alright, alright. I'll be careful, but only if you tell me the reason you climbed in my window in the middle of the night dressed in your best shirt and smelling like a new bar of soap. Surely not just to tell me to behave?

Reed looks down at his bedspread and coyly worries at its edges with his fingers.

Dan looks considerably taken aback. He looks away from Reed and out the curtained window, then back at Reed who is still fiddling with the bedspread. He is clearly lost for words, for he doesn't respond.

Reed sits up, rearranging the bedspread and smoothing it out in slow strokes, watching Dan expectantly, wondering if he will ever answer his question.

Reed's movement makes Dan start a little, he is clearly nervous and agitated.

\section{REED (CONT)}

Come on, tell me the real reason

you climbed in my window Dan

Baxter? Surely you didn't just come

to warn me about dumb Simon

Doncaster?

Dan swallows hard, looks out the window again and then, somewhat hesitantly, sits back down on the bed.

Dan's closeness causes Reed to feel both nervous and curious, for his body tenses a little as Dan sits, but his eyes look intrigued.

\section{DAN}

I like you Reed, always have. Ever since I first laid eyes on you years ago... You make it hard for a feller though-

\section{REED}

Making it hard for fellers is what I do best...

Dan's upper body jerks back in shock at this very forward comment, as if he's been struck. But he pauses only a second before he responds. 
DAN

There you go again. Don't you have any decorum at all?

\section{REED}

No, I'm afraid not. Besides, 'decorum' is a strange word for a bloke like you to use. Could it be there's more to you than meets the eye?

DAN

(meekly)

A whole lot more, if you're lookin'.

REED

I am looking.

Dan blushes.

\section{DAN}

Look Reed, I... I just don't know if

this is me.... If $I^{\prime} m$ the kind of guy who-

REED

Climbs in another man's window in

the middle of the night?

DAN

Yeah.

REED

Well, I don't know you very well, but I do know one thing for certain...

Dan's interest is piqued.

\section{REED (CONT'D)}

In this house, in my room, you can be any kind of man you want to be. It doesn't matter who you are outside, when you're with me, you can be whoever you want, whatever you want.

Dan smiles uncertainly, trembling a little. An awkward moment passes before he speaks. 
DAN

I don't know if I can be one person one place and a different person somewhere else.

REED

Sure you can, you can be whatever you want to be, whenever and wherever you want to. It's a myth

that we can only be one thing; that we have to be the same thing all

the time.

Dan looks as though he wants to believe this but isn't quite convinced.

DAN

Do you really think so Reed?

REED (CONT)

Yes, I do... Look, the same men who call people like me faggot on the street get up to all sorts of queer business when no-one else is looking. Everyone has secrets Dan, everyone.

Dan looks surprised by this, but not alarmed. There is another awkward pause before he speaks, in which he takes a deep, calming breath.

DAN

I'm sorry I didn't stand up for you

on the street, it's just-

\section{REED}

You didn't want your friends to think you were queer. It's okay, you're not required to stand up for me.

DAN

I know I'm not required... I wanted to, it's just, with everything-

REED

I understand perfectly. You don't need to feel obliged. 
DAN

And you don't need to cut me off

all the time. Let me say what I

came to say.

Reed is taken aback and goes quiet.

DAN (CONT)
I've wanted to come see you for a
while... but I thought if I knocked
on the door you'd just pretend you
weren't home.
REED
An astute observation. But, I must
say, I probably would've opened the
door eventually, I find you quite
intriguing.

Dan noticeably relaxes, he pretends to be interested in something amongst the clutter of knick-knacks on Reed's dressing table and smiles to himself.

Reed sees him smiling and smirks to himself as well, then sits up a little taller in his bed and straightens his pajamas.

DAN

I've never seen someone go to bed

with so much on.

REED

I'm an imperfect being, forgive me

if I hide behind a little

flannelette. It's all right for

you, with your glitteringly

handsome body.

Reed's face tightens a little, he fears that he may have gone too far too soon. But Dan smiles, clearly flattered. He soaks up the compliment for a while, then, acting on impulse, removes his white shirt, hanging it carefully on the bedpost before settling back on the bed again, slightly embarrassed, his hands resting awkwardly in his lap.

\section{DAN}

(doubtful)

Does it really glitter, my skin?

\section{REED}

It does to me.

Dan looks down at his chest, as if inspecting it. 
DAN

It's just the moonlight coming in

the window.

\author{
REED \\ No, no it's not just the moon.
}

They look into each other's eyes, a moment of understanding passing between them.

Reed swallows with nerves. Dan stretches his hand across the covers towards Reed's thigh.

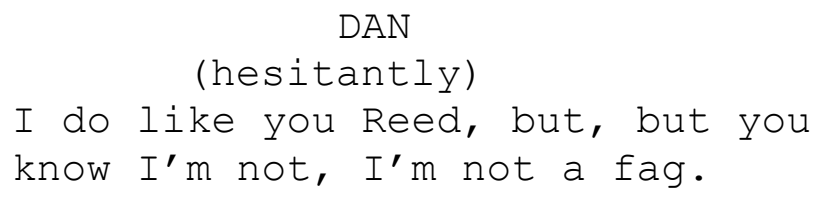

Reed flinches at the word 'fag', but recovers quickly.

$$
\text { REED }
$$

So, why is your hand on my leg?

DAN

Well, like you said, when it comes to you, I feel, well, different to normal.

\title{
REED
}

So, what, I make you feel abnormal?

Is that what you're saying?

Dan smirks, traces his hand a little higher on Reed's thigh.

\section{DAN}

No, not abnormal. You make me feel good... like I'm... like I'm beautiful or somethin'.

\section{REED}

You are. You are beautiful.

Dan blushes, smiles again.

DAN

I like you a whole lot, Reed. I've been desperate to climb in that window for months, to see you on your own...

Really?

\section{REED}


Yep.

DAN

Reed puts a hand to his chest, rubbing at a spot directly above his heart.

REED

My heart needed to hear that.

Sometimes I think the only emotion

anybody ever feels for me is

hatred.

DAN

I'm sorry if I made you feel that

way. I don't hate you, I... well, I

think you're beautiful too.

Dan places a tentative hand on Reed's shoulder.

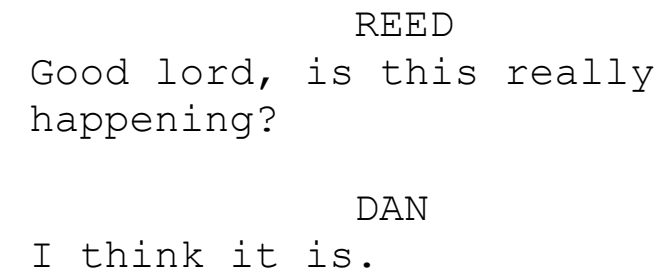

REED

How extraordinary-

Dan moves closer to Reed, caresses his cheek with a trembling hand. Reed looks both frightened and thrilled. Dan takes another deep breath, then leans in close to kiss him.

CUT TO:

\section{EXT. REED'S HOUSE- NIGHT, CONTINUOUS}

Outside Reed's house, the wind has slowed to a gentle breeze. The yard is still. The curtained bedroom window, still open, is dark, quiet.

THE END 


\section{Research statement}

\section{Research background}

This creative work is inspired by queer theory relating to gender and sexuality. More specifically, it is a creative expression (in the form of a script) of queer notions of gender and sexuality as diverse, fluid and changeable (Baker 2011). The creative piece is directly inspired by the critical work of Judith Butler (1990, 2004). In line with Butler's work, the script presents masculinity and male sexuality as free of any ontological basis.

\section{Research contribution}

The critical work that inspired this script was groundbreaking in that it illustrated the ways that gender and sexuality are discursive and performative constructs (Butler 1990, 2004). The script then, is innovative in that it presents, demonstrates and expresses these critical ideas in a creative way, something that has not been explicitly done in script form. The theoretical ideas have been deployed as characters, action and dialogue (Batty 2014: 35), in the accessible format of a drama script.

\section{Research significance}

This work is one of the first Queer Theory informed, creative applications of ideas around the fluidity of masculinity and male sexuality. The work is innovative in that these theories have been rendered as action, character and dialogue in a drama script (Batty 2014). The script is also a wholly original creative work, considered worthy of publication in TEXT, a peak journal in the creative writing discipline.

\section{Works cited}

Baker, D J 2011 'Queering practice-led research: subjectivity, performative research and the creative arts' Creative Industries Journal 4 (1): 33-51

Batty, C 2013 'Frankie goes to Hollywood: a comedy script' TEXT: Journal of Writing and Writing Courses, Scriptwrititng as Creative Writing Research, Special Issue 19: 1-35, http://www.textjournal.com.au/speciss/issue19/Batty.pdf (accessed 10 December 2014)

Butler, J 1990 Gender trouble: Feminism and the subversion of identity Routledge, New York Butler, J 2004 Undoing gender Routledge, New York 


\title{
RMIT University
}

\section{Craig Batty}

\section{Dirty talk: scriptwriting, script editing and the creative process}

\begin{abstract}
:
Craig is a writer. And a script editor. And an academic. He is working as script editor on a series of short films that sit under the umbrella title of Dirty Talk - comedy dramas in the mockumentary form about couples' sex lives. Whilst trying to write his own film, he's grappling with style and tone in another writer's screenplay - namely whether or not having the manslaughter of a lollipop lady as the reason for the protagonist being in prison is, in his words, too camp. He is also thinking about the creative processes that take place during the development of a film script, and how they might be made visible. Dirty Talk: Scriptwriting, script editing and the creative process is a multi-narrative work that weaves together the screenplay, the writing of the screenplay and the editing of another writer's screenplay, and in doing so draws attention to the creative and pragmatic decisions that influence the creation of a screenplay. These include inspiration, writerly interactions with characters, peer review and the pressures of industry conventions.
\end{abstract}

\section{Biographical note:}

Craig Batty is Associate Professor of Screenwriting at RMIT University, where he is also Creative Practice Research Leader for the School of Media and Communication. $\mathrm{He}$ is a screenwriter, script consultant and script editor, with experiences in short film, feature film, television and online drama. He is author, co-author and editor of eight books, including Screenwriters and Screenwriting: Putting Practice into Context (2014), The Creative Screenwriter: Exercises to Expand Your Craft (2012), Movies That Move Us: Screenwriting and the Power of the Protagonist's Journey (2011) and Writing for the Screen: Creative and Critical Approaches (2008).

Keywords:

Creative Writing - Screenwriting - Script editing - Creative process 
1. INT. OFFICE ROOM - MORNING

CRAIG, an early-30s practitioner-academic, sits at his home office desk, Skyping on his laptop with UK-based writer SARAH, early $40 \mathrm{~s}$.

Sarah listens intently whilst Craig speaks keenly.

CRAIG

Yeah, so, we kinda felt that...

it was just... tonally speaking,

a little bit light.

(beat)

As in, funny, but kind of ... I

don't know, maybe too camp?

SARAH

Right ...

CRAIG

It's just that when you say

'lollipop lady', it's really

funny. You know? Let alone when

you imagine one.

SARAH

Ok, so did you have ... [any

ideas about something else?]

CRAIG

Like, the colour of the outfit.

PVC, or whatever it is. The

lollipop itself, of course.

(beat)

$\mathrm{He}^{\prime}$ s got to be in jail for

something pretty bad, like you

write. We just weren't sure about

the tone. It needs to be more ...

I don't know ... poignant? Middle

class? Not so camp.

SARAH

I can have a think, and then ...

[give you some ideas.]

CRAIG

We changed it anyway .

(beat)

only slightly. 
Awkward pause as Sarah waits to hear the change.

$$
\text { CRAIG }
$$

A child.

(beat)

In a wheelchair.

Craig smiles. Sarah looks to the corner of her eye.

2. EXT. STREET - MORNING

Craig walks down a cafe-lined street with his laptop. He chuckles to himself.

3. INT. TRENDY CAFE - MORNING

Craig sips on a hot skinny latte as he looks at his laptop screen. He goes to type something, then pauses. Pensive.

4. INT. COLOURFUL BOUDOIR-STYLE LIVING ROOM - EVENING

Craig walks around the room, as if looking for clues. He touches the fabric of the sofa. Lifts a cushion and sniffs it.

Suddenly, LOTS OF MEN arrive. They start to populate the room - sitting on the couch, on each other's laps, etc.

Craig is overwhelmed for a moment. He scans the men, careful not to catch anyone's eye.

LIAM, a wispy, thin camp guy, late 20s, throws himself across the men sitting on the couch. He laps up the attention - and he clearly wants to get groped.

TERRY, a rugged sporty-looking bloke, late 30s, hovers in the corner. Lost in his own thoughts.

Craig looks at Terry; then Liam; then Terry again. He squints his eyes - an idea is forming.

5. INT. TRENDY CAFE - MORNING

Craig takes a deep breath and starts to type, determined.

6. INT. COLOURFUL BOUDOIR-STYLE LIVING ROOM - EVENING (SCREENPLAY)

TERRY, a rugged sporty-looking bloke, late 30s, sits with his arm around LIAM, a wispy, thin camp guy, late $20 \mathrm{~s}$. 
LIAM

A real eye-opener.

(beat)

In more ways than one!

TERRY

Never thought I'd like it so

much. Not something you often ...

well ... with ...

LIAM

(slightly bitter)

Totally wasted on women. Not as

if it'd lead to anything.

Awkward look from Terry: maybe it already has ...

LIAM

(quick to change the

subject)

It was like learning a whole new

language for Terry, bless him.

( camp)

A whole new tongue to master!

Liam giggles into Terry, though Terry tries to keep straightfaced.

\author{
TERRY \\ (innocent) \\ Rimming was just the start.
}

7. INT. TRENDY CAFE - MORNING

Craig licks his lips to clear latte froth. He takes the teaspoon and scrapes the bottom of the glass, all the while looking at his laptop screen.

A moment, then he looks outside to the passers-by. The sun is shining and there's life going on out there.

Craig sits back and arches his shoulders. Takes a deep breath. He picks up the food menu but something outside catches his eye. He squints as a MIDDLE-AGED MANICURED WOMAN walks by, carrying an equally manicured small dog.

Craig slowly puts the menu down and, thinking deeply, begins to type again. 
8. INT. COLOURFUL BOUDOIR-STYLE LIVING ROOM - EVENING (SCREENPLAY)

Terry and Liam are now sipping from china cups. Liam is delicate whereas Terry has trouble handling his.

LIAM

I must confess, I really loved training him up. Still do.

TERRY

I'm getting there, eventually. It's not ... [that easy].

\section{LIAM}

You're telling me! I've always been the passive type - so they

tell me - but there was just

something about ...

TERRY

I like cuddles, too.

(beat, embarrassed)

It helps.

Liam leans forward and puts his cup down.

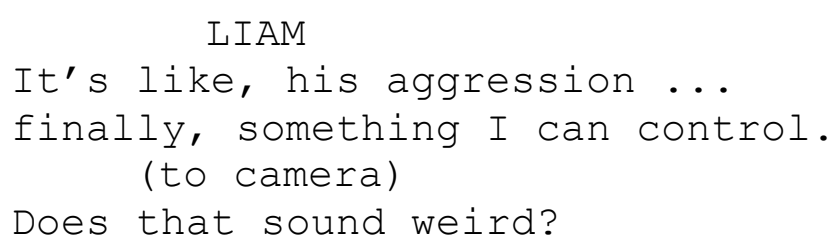

Terry suddenly remembers something.

TERRY

(to Liam, soft eyes)

Tell them about when we met.

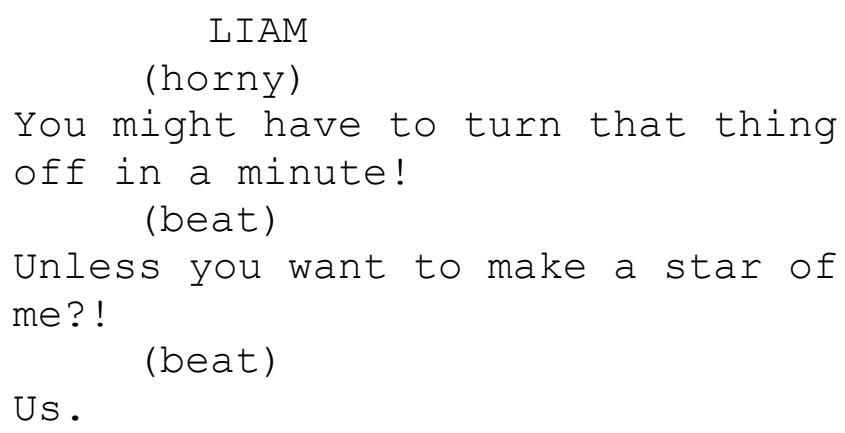

Terry holds Liam's hand, as if to calm him down. 


\section{TERRY}

It was the night of the funeral. Which I know sounds really bad.

\section{LIAM}

I'd been on a double-back

long-haul to San Fran, so

naturally I was gagging for a good night out.

\section{TERRY}

(sincere)

I'd kept it back for so long. I mean, how could I go out looking for ...

He glances towards Liam's groin, then quickly back at the camera when he realises what he's done.

\section{TERRY}

... when she was on chemo?

LIAM

(directly to camera)

There was both a sadness and desperation in his eyes.

(beat)

Not to mention a huge bulge in

his shorts!

TERRY

I'd been in a suit all day.

Liam leans forward, excited, almost overshadowing Terry.

\section{LIAM}

It was the hardest and longest

fuck I'd had since I was fifteen!

Terry winces at this comment. Liam sits back and grabs hold of Terry's hand - but it all looks quite rigid.

\section{LIAM}

He held me in his arms. I

could've gone again but I was on

standby and a call came through.

Terry puts his other hand over Liam's, to soften the grip. 


\section{TERRY}

He felt so ... gentle.

\section{LIAM}

Lagos

Liam gives a confident, slightly knowing look. Terry just looks awkward.

\section{INT. OFFICE ROOM - AFTERNOON}

Craig sits down at his desk and opens up his laptop. He goes to his e-mail and sees one from Sarah: the subject line, 'Crossing Patrol Operative'.

He opens the e-mail. It reads:

\section{Hi Craig.}

Good to chat earlier! Sorry about the connection problems - must have looked like one of those dodgy ads where young babes (!) repeat the same lewd act every 5 seconds!

Anyway ... just on the CPO aka Lollipop Lady thing, I had an idea. What if it were an old lady instead? Or maybe a cyclist? Just thinking - tonally, as you say! does a sick kid seem a bit... well, sick?!

Might just be my conscience. Not sure. I'm just having visions of that one from Glee, which doesn't help! (Have you seen it?)

Let me know anyway. Maybe ask Simon to see what he thinks?

Toodlepip!

Sarah $x$

Craig ponders for a moment. He goes to Google and types in 'Glee wheelchair'. He looks at the images that come up.

He goes back to Sarah's e-mail and hits 'reply'. He types:

\section{Hi Sarah!}

Thanks for your thoughts. Thoughtful, as ever! I get your point - maybe I/we don't have a conscience! though am wondering if killing a cyclist or a granny (granny on a bike?) is a bit 'basic'? Is it funny? Or just dark? Had a look at Glee and can see why you're 
concerned. But don't worry, we won't make the kid that old. Or as ugly! Let me ask simon ... leave it with me.

Interestingly, maybe - or maybe not - it's helping me to think about my own script. Tone versus credibility, etc. Good for the script editor to be writing too, don't you think? To try and create a series style.

Craig $x$

He hits 'send'.

10. EXT. BALCONY - AFTERNOON

Craig sits on his balcony, which looks out to the bay. He makes notes on a piece of paper:

Love. To be loved. What is love? Love 'Vs' sex. What is sex? Sex trainee? Where does love fit into all of this?

He suddenly remembers something and takes out his mobile phone. He types a message to Simon:

Hey, Simon. Hope the text doesn't wake you - afternoon

over here. Spoke to Sarah about her script. What are your thoughts on the wheelchair kid? Is it offensive or is it what we want, tonally? Just thinking about Julie's testicular cancer and Karen's sex cage. Craig $:-)$

He hits 'send'.

11. INT. COLOURFUL BOUDOIR-STYLE LIVING ROOM - EVENING

Craig sits on a chair opposite Terry and Liam.

CRAIG

So I'm thinking if we play it

lewd, it might have more pathos.

LIAM

What's that?

TERRY

As long as they get it. That's

the point, right? 
LIAM

Essentially, it's your story,

Terry.

Liam looks a little lost - it's not usual for him to be sidelined. Terry notices this.

TERRY

What about Liam?

CRAIG

I think he needs a climax, too.

LIAM

Now we're talking!

Craig ignores this comment.

CRAIG

It's a story about union - I

think. You're together, but

you're not.

LIAM

He loves me ... doesn't he?

TERRY

What about grief?

CRAIG

I'm thinking guilt. As in,

feeling like you're betraying

your... well, ex wife.

LIAM

Who else is in the series?

CRAIG

(slightly frustrated)

A retired couple. And older man and a younger woman. A couple who've fallen on hard times, and she has to sell her body to pay the mortgage.

TERRY

What kind of series is this?!

LIAM

The type I like! 


\section{CRAIG}

It might seem smutty, but it's actually about emotional journeys and subtext. What people say and do, versus what they're really thinking and feeling.

LIAM

(tongue-in-cheek)

Sounds like there's a lot of feeling going on ...

Terry playfully slaps Liam's wrist.

\section{CRAIG}

Sex is a frame, but the meat ... the content is about people's choices, and facing up to what's working and what's not. (beat)

I think.

Terry ponders for a moment.

\section{TERRY}

I think I get it.

(beat)

But you will ... do it

tastefully, won't you?

Craig looks at Liam, who's stopped listening.

12. INT. COLOURFUL BOUDOIR-STYLE LIVING ROOM - EVENING (SCREENPLAY)

Terry's now sitting alone on the sofa.

TERRY

He was really keen to show me all

he'd learned himself. How it works for ...' 'us' lot ... He decided on this A to $Z$ thing. (beat) We got stuck on ' $S$ ' for quite a while, but...

Liam re-enters with a tray of chips and dips. 
LIAM

It's quite hard to suck and spank

at the same time - you need a

good few days.

TERRY

(to Liam, warmly)

$D^{\prime}$ you remember the snuggling?

LIAM

That was nice.

(beat, matter-of-fact)

A night of nothing before we

started on the tea-bagging.

Liam offers Terry the tray of chips and dips. Terry falters for a second from Liam's comment, before quickly grabbing a handful of chips.

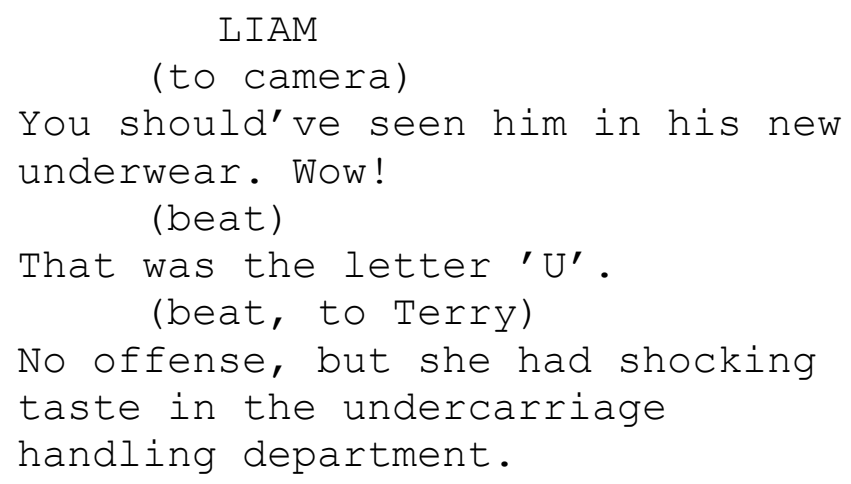

Terry smiles, obligingly, but then looks away, as if he's trying to conceal a sudden sadness. Liam dips a chip several times before gulping it down.

13. INT. BEDROOM - NIGHT

Craig is in bed. Just as he turns the light out, a text comes through from Simon:

I think it's fine. And it's not as if we have to film it. The actress can soften any possible cruelty?

Craig writes a reply:

My thoughts exactly. Let's not worry about offending. Good night!

He hits 'send'. 


\section{INT. TRENDY CAFE - MORNING}

Craig is in the same cafe as before. He's eating avocado smash with bacon. He looks at his laptop screen intently.

15. INT. COLOURFUL BOUDOIR-STYLE LIVING ROOM - EVENING

\section{(SCREENPLAY)}

Terry's now sitting on the edge of the sofa. Liam is laid out, his legs resting on Terry's lap. It looks a little awkward.

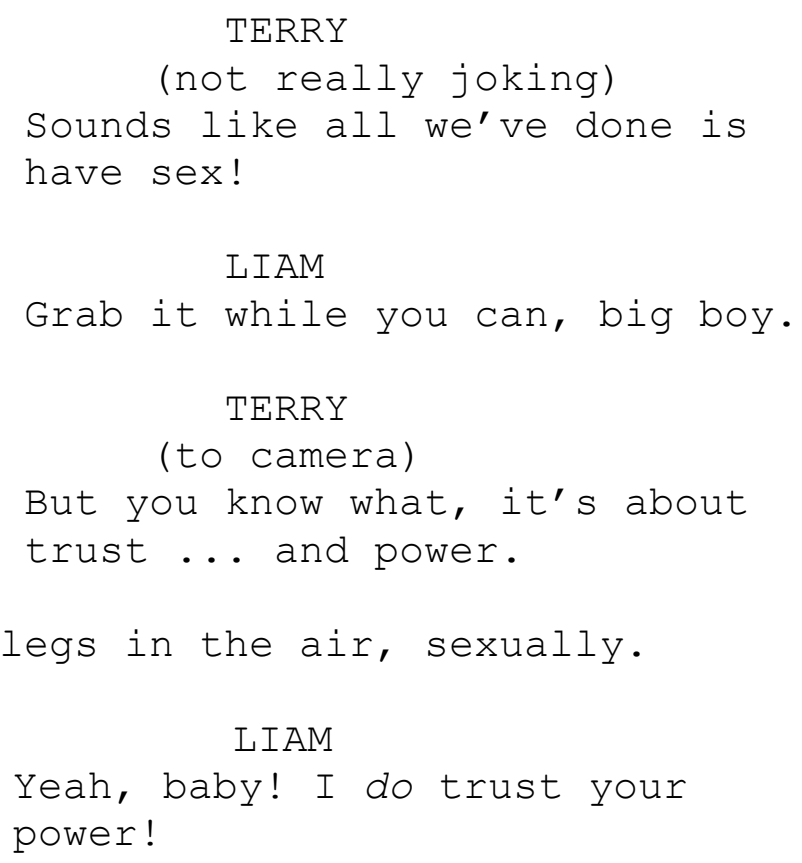




\author{
TERRY \\ (world of his own) \\ Afternoon walks ... bedtime \\ stories ... chats ... cuddles ... \\ chats and cuddles!
}

Liam's confused. He glances towards the camera, awkwardly, embarrassed. Then back to Terry.

$$
\begin{aligned}
& \text { LIAM } \\
& \text { Don't you find me attractive? }
\end{aligned}
$$

16. INT. TRENDY CAFE - MORNING

Craig stops typing for a moment. Thinks hard.

17. INT. COLOURFUL BOUDOIR-STYLE LIVING ROOM - EVENING

Craig walks over to Terry and Liam.

CRAIG

This is the key line of the

scene, ok?

\title{
LIAM
}

Is he going to say no?!

Precisely!

CRAIG

Liam looks scared - but Terry thinks he knows what's going on.

CRAIG

I mean, yes, he does find you

attractive. But this line is

about you. Your vulnerability.

What you're really saying is ...

TERRY

Don't leave me. I need you.

CRAIG

Yes, good. Sex aside, you, Liam, need Terry. Need. You're actually

nothing without him. No offense. This

is where you enter the inmost cave ...

Liam raises his eyebrows. 
CRAIG

(annoyed)

stop it!

(beat)

And you realise who you are. And

for the first time, Terry sees

who you really are. He knew it

anyway, but here, you let him see

it for the first time. Probably.

TERRY

This is good.

CRAIG

It'll all change in production, I'm sure, but here's the intent anyway. The director can tease it out. He's good. We work closely on understanding the story. And refining the tone.

Terry and Liam look at each other - sounds ok?

CRAIG

Ok - here goes ...

18. INT. COLOURFUL BOUDOIR-STYLE LIVING ROOM - EVENING (SCREENPLAY)

\author{
LIAM \\ Don't you find me attractive?
}

Terry just smiles affectionately. He strokes Liam's face.

LIAM

I thought you loved me?

Terry kisses Liam's forehead, very tenderly.

But Liam is lost. He starts pulling at his clothes, selfconsciously.

Terry looks at the camera.

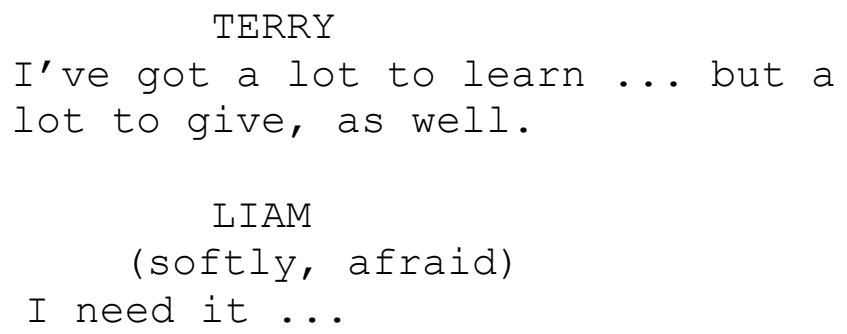




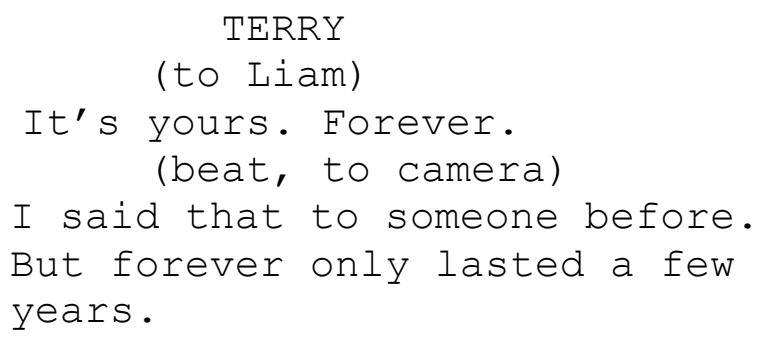

It suddenly dawns on Liam that he's been quite silly in front of the camera.

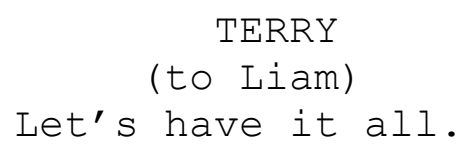

Liam nods; he can't bring himself to speak.

TERRY

Not just sex.

(beat)

Plenty of sex ...

Liam smiles, but in an understanding kind of way.

\section{TERRY}

... but not just sex.

A tender moment as Liam and Terry embrace.

Screen fades to black.

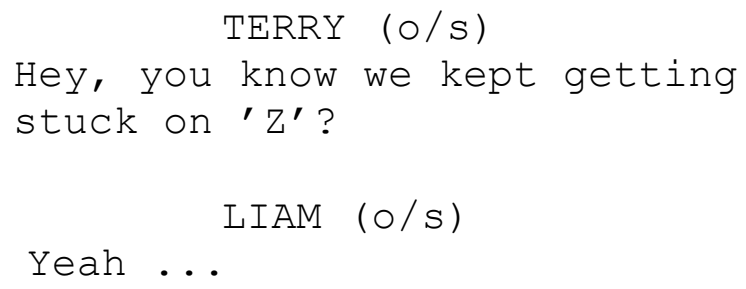

19. INT. OFFICE ROOM - AFTERNOON

Craig reads an e-mail. A reply from Sarah:

Hi again!

Ok, let me know. You know the series, of course, and Simon is directing. Just think about the politically correct brigade! Is there a modern day version of Mary Whitehouse, by the way?

Skype soon? Oh, hang on a minute... (why do we still 
write e-mails in the order we think, when we can cut and paste?!) ... what about a parking inspector, someone like that? Kind of sad, but kind of ironic? It'd make me laugh if I saw it!

Sarah $x$

\section{EXT. STREET - AFTERNOON}

Craig walks down the street with a bag of shopping. He notices a PARKING INSPECTOR on the other side of the road.

Craig pauses to watch him for a moment. The parking inspector is friendly, spending more time saying hi to people than checking the meters.

Craig squints at this, looking slightly unimpressed. He walks on.

Just as he's about to turn a corner, a woman in a mobility scooter careers towards him. He's taken aback - literally and conceptually.

A beat, then he has an idea.

21. INT. OFFICE ROOM - AFTERNOON

Craig is frantically typing a reply to Sarah:

Hey!

On reflection, you're right. Tonally, it's probably a bit screwed up. Simon and I have given it a LOT of thought - be assured! - and we came up with a great solution... an old woman in a scooter! you know, those mobility ones. I don't think it's as sick as a child? Also, yes it's clear that she's old - but viewers might (hopefully?!) also get the impression she's disabled in some way. Which is great!

I'll make the script amendment and send to Simon. He's hoping to cast next week. Thanks for your efforts!

Craig $x$

He hits 'send'. 


\section{Research statement}

\section{Research background}

This work sits within the emerging field of screenwriting practice as research, and more specifically, the screenplay text as research. Inspired by recent debates about the value of screenplay creative practices and artefacts within the academy (Millard 2010, Baker 2013, Batty 2014), the work is situated as a text that not only speaks about screenwriting research, but also performs screenwriting research through form and content. As a screenplay, the work also sits at the intersection between creative writing research, which is firmly embedded in the academy, and screen production research, which has yet to find its own discourse in the academy.

\section{Research contribution}

As a multi-narrative work that weaves together the screenplay, the writing of the screenplay and the editing of another writer's screenplay, the screenplay draws attention to the creative and pragmatic decisions that influence its creation. These include peer review, inspiration, writerly interactions with characters, and the pressures of industry conventions. Found in both the screenplay's content and its form, these aspects present an intertextual work that is aware of its origin and its purpose, including its place in the academy.

\section{Research significance}

This work is one of only a handful of published 'academic screenplays' in the world, and builds on the author's extant published works of a similar style and purpose. It is significant in that its research contribution is evidenced through both content and form. Furthermore, it works on the level of reflexivity, meaning it can be viewed as a research tool as well as a research outcome - speaking as much about screenplay development as it does screenplay content and form. This gives it further importance within an academic context.

\section{Works cited}

Baker, D 2013 'Scriptwriting as creative writing research: a preface' TEXT: Journal of Writing and Writing Courses Special Issue 19: 1-35, http://www.textjournal.com.au/speciss/issue19/Batty.pdf (accessed 10 December 2014)

Batty, C 2014 'Introduction' in Screenwriters and screenwriting Basingstoke, Palgrave Macmillan, 1-7

Millard, K 2010 'After the typewriter: the screenplay in a digital era' Journal of Screenwriting 1(1), 11-25 


\title{
Griffith University
}

\author{
Debra Beattie
}

\section{John and Jennie}

\begin{abstract}
:
This script is dedicated to the memory of all those friendships and loving relationships marred, and often destroyed, by the sectarianism so prevalent in country Queensland in the years before Statehood. John and Jennie draws on accounts from The Gayndah Communes about this period of Queensland history just before the outbreak of the first world war. The script highlights the continued negation and absence of the history of how sectarianism disrupted the lives of ordinary Queenslanders, particularly in terms of who they could marry. In this the year of commemoration of Australia's involvement in the first world war, it is timely to recall and to reimagine the everyday lives of those who loved and lost in a time of deep prejudices. This script is part of an ongoing research project and creative practice in the area of historical reimagining.
\end{abstract}

\section{Biographical note:}

Debra Beattie is an Australian filmmaker, screenwriter, scholar, and teacher. She has produced and directed documentaries in Australia for over thirty years with a diverse group of communities, indigenous, Indonesian, and Melanesian. Most recently she was the associate producer on Zen and the Art of Dying (2014) and Fairweather Man (2008) an ABC television documentary on the life and times of Ian Fairweather, an artist who lived on Bribie Island in the 1960s. Beattie is a creator, a scholar of new media documentary and social engagement. In 2001, she directed The Wrong Crowd a pioneering web-based documentary for ABC Online; and in 2004 developed design best practice for online counselling as Chief Investigator on ARC Discovery with Kidshelpline. Since 2006, she has engaged in delivery of documentary in public places such as galleries, museums and libraries, and published screenplays on historical Australian stories.

\section{Keywords:}

Creative Writing - Scriptwriting - Sectarianism - Conscription - Queensland History 


\title{
John and Jennie
}

\author{
The Characters
}

BOB - an old man in his eighties, country bred, well read.

JACK JNR - in his 60s and a mourner at TOMAS' Funeral

\section{0s}

TOMAS - 19, Italian migrant, Catholic, sent into country Queensland to teach at the first ever school in the district

JOHN - 18, Irish Catholic, eldest son of the fiery Brigid

BIDELIA - 18, dark-haired Irish Catholic daughter of the owner of Gorroolba Hotel, Patrick Delaney

JENNIE - 18, golden haired daughter of a Northumberland miner

BRIGID - mid 30s, Irish Catholic mother to JOHN her eldest son

\section{4}

TOMAS - 33, married to BIDELIA

JOHN - 32, enlisting in WW1

BIDELIA - 27, with toddler Thomas.

JENNIE - 32, with two sons, the eldest called JACK (and another on the way) as war declared

WILLIAM - 37, pastoralist, Jennie's husband

WILLIAM SNR - JENNIE's father, late 50s

\section{Note}

The film's opening credit is a close and textured montage of the details of a beautifully embroidered silk handkerchief with the letters $J$ and $J$ entwined into the shape of a heart, sewn with long strands of thick golden hair. This 'billet doux' was kept in a cigar box for over fifty years. 
JOHN AND JENNIE

1.EXT. CEMETERY CATHOLIC FUNERAL IN PROGRESS - 1968

$\mathrm{BOB}$

Jack, I found this small box

amongst Teacher Ped's things. Biddy

thinks you should be the one to

keep it now.

Jack Junior looks at the box in Bob's hands

There is a slow cross-fade from $\mathrm{BOB}^{\prime} \mathrm{s}$ old face to a much younger $\mathrm{BOB}$ and JOHN in their teens, in a matching tableau.

\title{
TITLE PAGE : COUNTRY QUEENSLAND, 1900
}

2. EXT. WOOD/BARK HUT/ THE NEW SCHOOL

BOB is 16, a bookish boy, and his best friend, JOHN, a year older, a handsome, intelligent, muscular, hardworking, eldest son of one of the staunchest Irish Catholic families in the District.

JOHN is swinging the hammer with gusto as he finishes the verandah railing.

TOMAS is the new teacher, the first ever in the District. He is only 19 and has just arrived by horse, carrying his saddle with him.

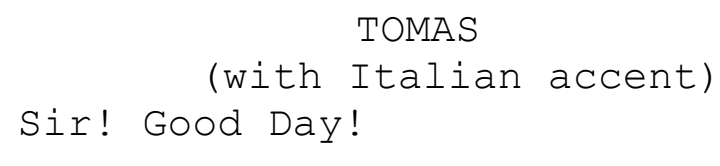

JOHN

Ah! Mr Pedrazzini!

TOMAS

I left my horse tied to the gate.

\author{
JOHN \\ (calling to $\mathrm{BOB}$ ) \\ Bring her up and give her some \\ water and feed, Bobby. \\ TOMAS \\ (with a long deep whistle) \\ so this is the schoolhouse?
}


John nods proudly.

\section{TOMAS}

Just in the nick of time, eh?

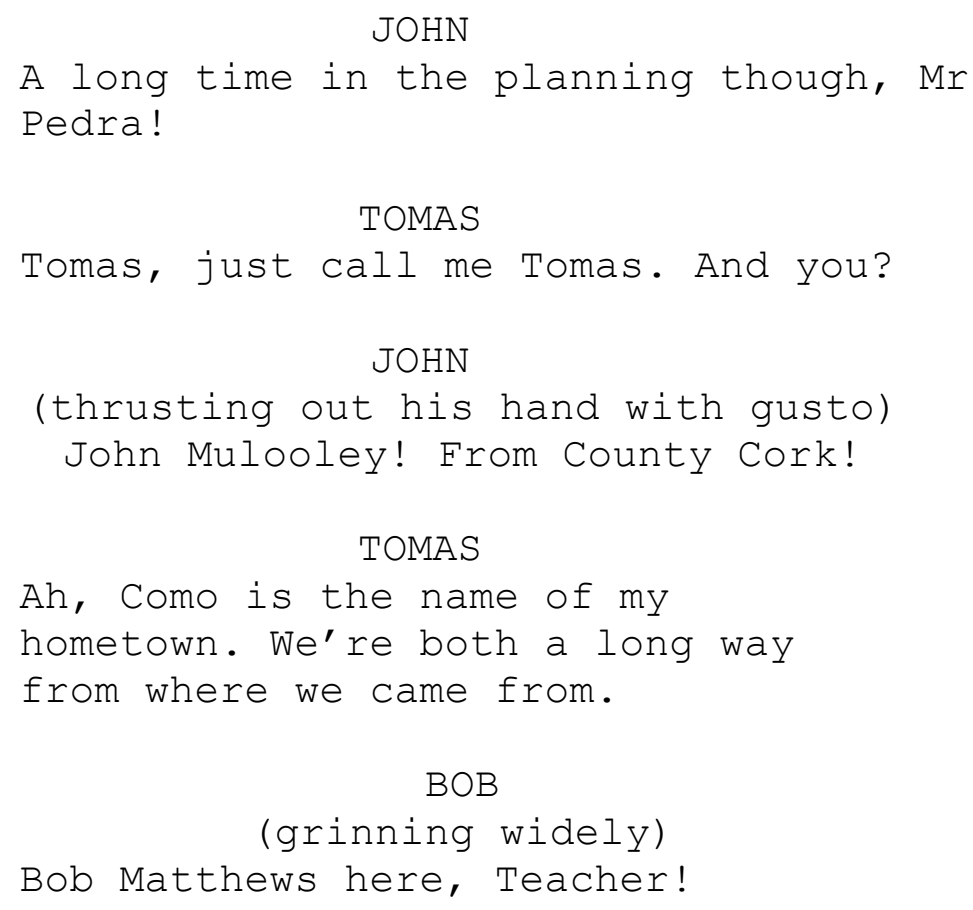

BRIGID DELANEY enters with a plate of sandwiches. She is a tall and formidable Irish Catholic mother. The faith is held close by his family, and BRIGID has been a key advocate and driving force in the building of the new school, and is very proud of it.

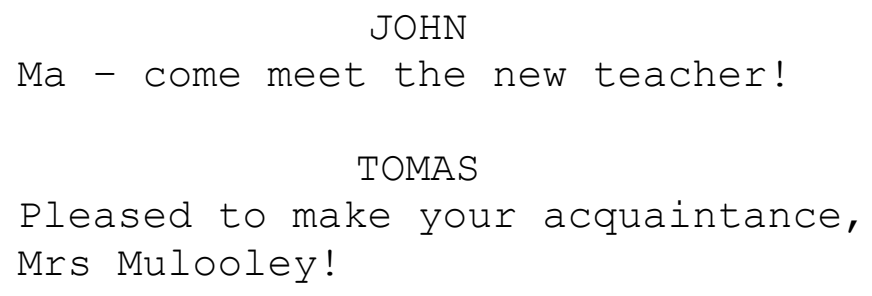

BOB, JOHN, TOMAS and BRIGID all enter the schoolhouse hall.

2. EXT. SCHOOL HALL, NIGHTLIGHTS, DANCE IN PROGRESS

JOHN and TOMAS are carrying a ladder away after fixing the lights in place, in the midst of an earnest conversation. 


\section{TOMAS}

When I left Italy, John, the police violence... ah, it was becoming so harsh. Many people had started stealing bread.

JOHN

When I was a kid, the old shearers were always yarnin' about the Shearer's strike, the riots, the police bashing 'em, sounded real bad.

TOMAS offers to teach JOHN how to read in the evenings after their working day has finished.

\section{CUT TO:}

\section{INT. THE DANCE}

A bush dance is a lively event. There are the beautiful Lutvey girls from Lebanon. There are the boys from the Ping family from China. There are the Irish Catholics, and there are the Wesleyans.

JENNIE arrives with her family, Wesleyan migrants to the District with the promise of land.

TOMAS and JOHN enter, causing a stir as they enter laughing uproariously, full of optimism.

TOMAS is smitten by the lovely BIDELIA (aka BIDDY, daughter of the owner of the Gooroolba Hotel. TOMAS and BIDDY dance happily, comfortable in an easy friendship.

JOHN meets JENNIE and there is a clear mutual and instant attraction.

JENNIE is taken, somewhat forcefully, by her father to meet WILLIAM, the son of the Wesleyan chaplain.

Later in the evening JOHN and JENNIE dance together.

BRIGID, John's mother, is cold and disapproving as they prepare to leave the hall.

\section{BRIGID}

Catholics can only marry other Catholics, you know that, don't you John? 
4. EXT. SCHOOL HALL

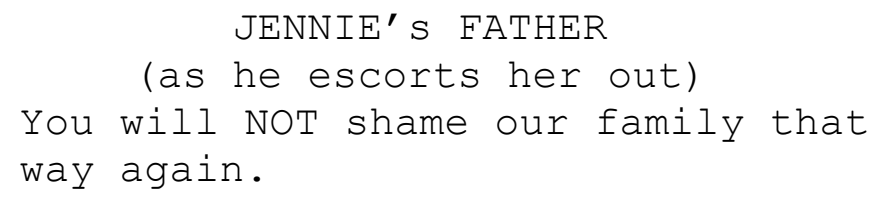

JOHN and BRIGID walk by.

BRIGID

No good will come of it John, just let it go.

CUT TO:

5. INT. JENNIE'S BEDROOM - LIT BY KEROSENE LAMPLIGHT

JENNIE is sitting by the lamplight and sewing her long golden hair into a handkerchief with two initials intertwined - J and $J$ - as a heart.

A montage of memories of the dance swirl around her in the dark as she sews.

She remembers JOHN playing with her long golden hair.

JOHN

You're all I want, Jennie - you and a proud place in this great land.

CUT TO:

The following two scenes are static 'mise en scene' of a few seconds each.

6a. INT. JENNIE's drawing room

WILLIAM the chaplain's son has come courting. JENNIE's parents are very happy.

JENNIE is sad but compliant.

6b. EXT. WESLEYAN CHURCH

JENNIE and WILLIAM exit the church as a married couple. $\begin{array}{lcccr}\text { FADE SLOWLY TO THE TREE } & \text { IN } \\ \text { THE CHURCHYARD } & \text { TO } & \text { SHOW } & \text { THE } \\ \text { SEASONS PASS BY. } & & & \end{array}$ 
7. INT. JOHN'S BEDROOM

ABC RADIO playing in background.

\author{
MENZIES PM \\ England is at war and so Australia \\ is at war.
}

TOMAS is standing at the window as JOHN is packing his swag. There is a small cigar box into which JOHN is gently placing a dried wattle flower and some letters, scented, which he smells nostalgically as he places them, and the delicately embroidered silk handkerchief that JENNIE has sewn for him.

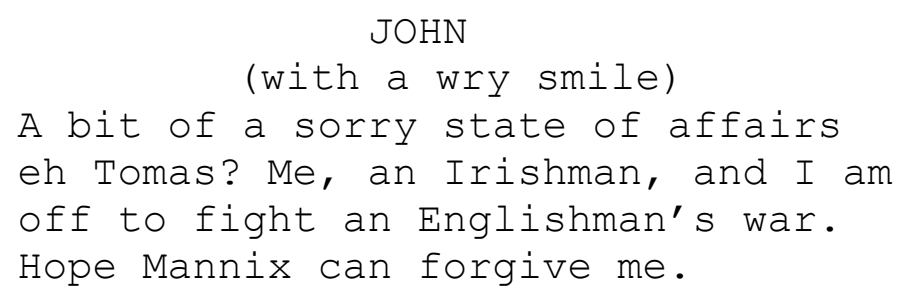

JOHN gives the small cigar box to his friend TOMAS. TOMAS hugs JOHN.

TOMAS

I promise to keep it safe until you return.

CUT TO:

8. EXT. ROAD - EARLY LIGHT

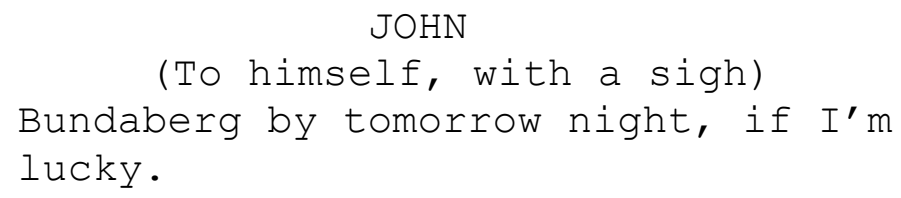

JOHN is walking out of town with his swag and is picked up by a horse and dray.

POV JOHN looking back at JENNIE heavily pregnant, on verandah.

POV JENNIE watching JOHN disappearing down the road.

CUT TO: 
TITLE UP: THE WAR YEARS DRAG ON

\section{EXT. SCHOOLHOUSE VERANDAH - MORNING}

JENNIE's eldest boy JACK is now 5 years old, and is about to start school. There is also a toddler at her skirts, a baby in her arms and another one on the way.

BIDELIA's eldest is TOM and he is a toddler still.

JENNIE

You know Biddy, all the Wesleyan

lads enlisted. It was only the

Catholic boys who hesitated.

BIDELIA

Well, Archbishop Mannix did take a

very strong stand against

conscription.

TOMAS rings the bell and the children enter the

schoolhouse ushered along with BIDDY's help. The door closes

CROSS FADE :

Door Closed with NOTICE: SCHOOL CLOSED. PINNED WITH NEWSPAPER HEADLINE - "FLU EPIDEMIC"

CUT TO:

10. INT. JENNIE and WILLIAM's HOME - EARLY MORNING

TITLE: APRIL 1920 a few days before the first Anzac Day.

JENNIE is sewing celebratory ribbons .

The children are waking up and bustling in to the kitchen, ranging from JACK who is now ten, and three other boys, the youngest a toddler.

WILLIAM is putting on his boots to head off to the paddocks with the men to clear prickly pear. It is already a very humid day. It will be hot and uncomfortable work.

JENNIE walks over to the mantelpiece and sighs as she looks at her wedding photo. It is JENNIE AND WILLIAM'S wedding anniversary. 
JENNIE

Thirteen years ...

JENNIE turns to WILLIAM for a kiss. He does not remember the anniversary, and does not kiss her.

CUT TO:

11. EXT. FRONT YARD, JENNIE AND WILLIAM'S -LATE MORNING

The four boys are all busy in the yard outside with various chores. A letter arrives for William and Jennie. It is from William's mother. JENNIE opens the letter and is very teary on reading it.

JACK, Jennie's eldest son, asks about taking lunch to Dad out in the paddock, and JENNIE leaps to her feet and rushes to make WILLIAM a sandwich.

CUT TO:

12. INT. JENNIE and WILLIAM's DINING TABLE - AFTERNOON

JENNIE is still sitting at the table with the letter. WILLIAM arrives and is very annoyed at missing his lunch.

\section{WILLIAM}

Why did you forget about me?

JENNIE

Oh when do I ever forget that I am married to you?

JENNIE rises to makes another lunch for William. As WILLIAM eats, she tells him about the letter.

JENNIE

'Tis such a sad letter... You

remember the grocer's boy? He wanted so badly to go to war but the father had been so against it? His mother argued the case and the boy enlisted.

WILLIAM

Ah that Irish Catholic coward of a father. Good on the boy!

JENNIE is stung by this response. 
JENNIE

The boy worked as a medic on the Western front, and survived! so, so very sad. Then it was he died, William, on the boat home, from that dreadful flu.

JENNIE has tears in her eyes as she relates the tale and it clearly has an effect on her.

The rain is getting heavier, and WILLIAM declares that he needs to get back to the paddock.

JENNIE is left alone. She watches WILLIAM leave.

In her mind, she sees JOHN lying somewhere, left to die alone in the mud and rain.

CUT TO:

\section{EXT. COTTAGE YARD - LATE AFTERNOON}

A loud clap of thunder and JENNIE has rushed to the verandah. The lightning flashes and the downpour increase unabated. JENNIE is in a state of high anxiety.

JOHN appears at the front gate.

JENNIE walks towards him. She is thinking that this is yet another of her imaginings, that this will be another ghostly presence so often in her mind.

She reaches out to him. He is real. She jumps back in shock.

$$
\text { JOHN }
$$

Are you happy, Jennie?

JOHN reaches for her and they embrace. There is more lightning and thunder and it is now JOHN who jumps like a frightened child.

JENNIE feels she needs to conceal her true state in order to protect him. She wants desperately for JOHN to be okay, and not to be worried about her.

JENNIE

Why yes John, perfectly happy. 
JOHN, ever the gallant, gives her one long loving look and walks away into the increasing downpour.

CUT TO:

\section{INT. JENNIE'S DINING ROOM - DUSK}

JENNIE is in an increasingly agitated state and is writing at the kitchen table.

\section{JENNIE}

Oh what have I done? I shouldn't

have let him go... Not again!

Her words ... 'Dear William' ... and then she scratches out and rewrites ...

"Not good enough ...never good enough ... better for you to have a good wife ... tried to be good ..."

The final shot of this scene is the letter finally written, sealed, addressed and placed on the side table by door. JENNIE is at the door, with her wide brimmed hat being placed firmly on her head.

CUT TO:

\section{EXT. WILLIAM and JENNIE'S HOUSE - SUNSET}

A worker, out cutting prickly pear all day in the heat and dirt, arrives back at the house. All four of the boys, JACK, 12, MATTHEW, 9, MARK, 6, and LUKE, 3, rush to him to say that their mother is not there and they don't know where she is.

CUT TO:

16. INT. WILLIAM and JENNIE'S - HOURS LATER

WILLIAM arrives home at $7 \mathrm{pm}$. He is angry. He is worn out. As he opens the front door, the letter on the side table falls to the floor in a gust of wind.

\section{WILLIAM}

Where is your mother?

On hearing that JENNIE is not home, WILLIAM searches the house angrily for any note but finds none.

CUT TO: 
17. EXT. YARD

WILLIAM leaves the boys and takes his saddle. He explains to them that he must ride immediately to his father's home (three miles away) to tell him that JENNIE is missing .

18. EXT. WESLEYAN CHAPLAIN'S HOUSE

WILLIAM's mother and father, the Wesleyan chaplain and his wife both tell WILLIAM that he must start searching immediately.

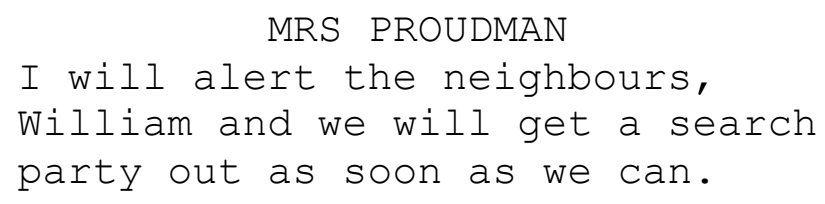

CUT TO:

\section{INT. TOMAS HOUSE - FRONT ROOM}

JOHN is there, a broken man.

TOMAS is trying to return the cigar box to him.

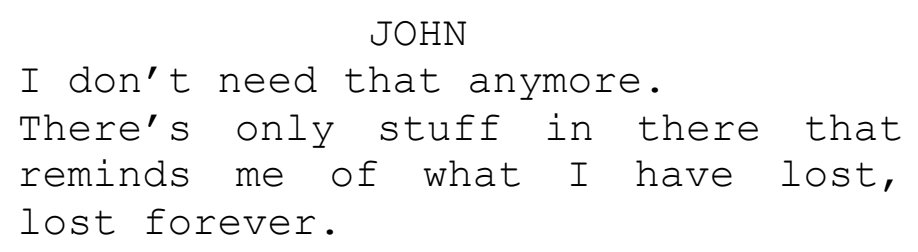

There is a loud and urgent knocking at the door. JOHN is startled badly again, reacting fearfully to the loud noise.

CUT TO:

20. EXT. TOMAS' VERANDAH

TOMAS opens the door. The search party is asking TOMAS to join them. Sadly, the group consists of many of the same people who had been at that carefree dance so many years ago.

21. INT. WILLIAM AND JENNIE'S HOUSE - HOURS LATER

The storm has worsened. Windows are rattling. The rain is pounding on the roof. 
WILLIAM enters the house, and sits on the chair by the door. As he takes off his boots, he finds the note that he missed earlier, in his rush and panic. The letter had fallen to the floor with a gust of wind when the door opened.

He reads JENNIE's words and we hear her voice, she writes that her 'constitution is gone and her nerves are broken'. She says that she believed that William 'was always vexed with her of late', and protests that she had been a good and honest loving wife - 'a True wife, and William had nothing to be jealous of'.

The words are spoken in the voice of a deeply distressed woman. She writes 'I have a need for Baptism, a need for the cleansing waters, of the rising waters, to bathe my soul'.

CUT TO:

\section{EXT. CREEK BANK - MIDNIGHT}

TOMAS and $\mathrm{BOB}$ and JOHN are still searching around the creek bank, even though the searching has been called off, as the steadily rainy night hampers their efforts. Feet walk past the very pretty hat, high on the bank, but it is not yet found.

CUT TO:

\section{EXT. CREEK BANK - DAWN .}

The search resumes. Dawn chorus after the heavy rains. Within a few minutes, and only a hundred yards from where they had camped, TOMAS finds Jennie's pretty hat on the high bank of the creek.

The searchers continue with the search but now are dragging the creek from a boat.

JOHN is at the front of the boat and sees the body first, caught by a deep tree root and submerged in nine feet of water.

JENNIE's body is dragged out by her shoulders and placed on the high bank. Rigor Mortis has set in, but her arms have strangely been positioned neatly and firmly crossed on her chest. 
24. EXT. GAYNDAH CEMETERY -JENNIE'S FUNERAL.

The eulogy is a very sad one, for an only 37year old Wesleyan wife who had been married to one on the District's most upstanding members, a mother to four young boys who now stand around the gravesite, with their father WILLIAM, emotionless.

TOMAS and BIDELIA are there with their three children.

JOHN is there, but very much in the background, a broken man in body and heart and soul.

$\mathrm{BOB}$ is there and looks towards JOHN sorrowfully.

Young JACK, JENNIE'S ELDEST SON, walks over to BOB and is comforted by the older man.

There is a crossfade from this BOB to the old BOB as he was in the first scene, and JACK as now a much older man himself.

25. EXT. CEMETERY - TOMAS' FUNERAL in 1968

Old BOB has given JACK the cigar box. JACK decides to open it, and there is the handkerchief with the two entwined initials sewn with JENNIE's long golden hair.

FADE TO BLACK.

END OF SCRIPT 


\section{Research statement}

\section{Research background}

This script draws upon accounts in The Gayndah Communes about this period of Queensland history just before the outbreak of the First World War (Metcalf 1998). The narrative structure is also informed by the historical accounts of the conscription issue by noted historian, Raymond Evans (2007). The details of the funeral and the silken handkerchief kept hidden for over eighty years were drawn from a journal written by local resident Robert Matthews, one of Teacher Ped's first students. The script is therefore a blend of 'history from below' or 'alltagsgeschichte' (Ludtke 1995), the history of everyday life, as well as more formal accounts by historians of issues impacting on those lives.

\section{Research contribution}

My contribution to research of historical accounts include Fairweather Man (2008) and The Bounty (2013). Like these earlier works, this work draws on a creative practice methodology that constructs an imagined explanation for the absences in the historical records of everyday life. Both of these earlier works provided accounts of gaps in the historical record of the lives of public figures, painter Ian Fairweather and filmmakers Elsa and Charles Chauvel. This script builds on these earlier works and develops my research and creative practice in the area of historical reimagining.

\section{Research significance}

This script John and Jennie highlights the continued negation and absence of the tragic stories of sectarianism that dogged the lives of early Queenslanders in the early part of the twentieth century - particularly in terms of who they could marry. In this the year of commemoration of Australia's involvement in WW1, it is timely to recall and to reimagine the everyday lives of those who loved and lost in a time of deep prejudices. This creative and research work is innovative in reimagining this history in script form. It is also a wholly original creative work considered worthy of publication in TEXT, a peak journal in the Creative Writing discipline.

\section{Works cited}

Beattie, D 2013 'A critical introduction', TEXT: Journal of Writing and Writing Courses Special Issue $19,1-35$

Evans, R 2007 A history of Queensland Cambridge P, Melbourne

Ludtke, A 1995 The history of everyday life Princeton UP, Princeton, New Jersey

Metcalf, W 1998 The Gayndah Communes Central Queensland UP, Rockhampton 


\title{
Central Queensland University, Australia
}

\author{
Susan Davis
}

\section{Questions for George}

\begin{abstract}
:
What lies at the heart of our creative and research journeys? Are we always seeking to understand something about ourselves no matter what the subject? What makes writing and the creative journey worthwhile? Is it acknowledgement in our own lifetime or a belief in leaving some form of literary legacy? This script ponders such questions as the researcher explores, in creative form, her journey to answer questions about the life of one of Queensland's early playwrights, George Landen Dann who came to prominence in 1931 when he won the Brisbane Repertory Theatre playwriting competition with the play In Beauty it is Finished. Dann later became one of Australia's leading playwrights. Critics, publishers and directors (Brisbane, 1977; McCallum, 2009, Rees, 1973; Rowbotham, 1962) have long argued that Dann's work deserves greater recognition. This script examines events from the time of a 1930s scandal, making links to events from his final years and the significance of the work of an Honours student who wrote her thesis about him. The researcher's own questioning frames the investigation, creating a Readers Theatre style of documentary script drawing on evidence from interviews, newspaper clippings, letters and other documents in the Fryer Library collection at the University of Queensland.
\end{abstract}

Biographical note:

Susan Davis is a Senior Lecturer at CQUniversity, a writer and researcher with extensive experience in drama, theatre and education. She has directed dozens of plays and written many scripts, two recent ones include Epiphany and Figments of Eliza, both published in TEXT. Previously, she was a drama teacher and Performing Arts Head of Department, creating many youth theatre performances in collaboration with various industry partners in Brisbane and on the Sunshine Coast. She has an ongoing interest in activating history through drama. Her research about the life and work of George Landen Dann has contributed to the publication of four of his plays, including notable works not previously published.

Keywords:

Creative writing - Creative nonfiction - Drama - Australian theatre 


\section{Questions for George}

\section{The Characters}

This script has been written as a Readers Theatre or radio script. The intention is for a number of readers (probably three or four, including two or three females and one male) to present the script with simple staging and no suggestion of specific locations.

RESEARCHER - A female figure representing the author, who has been researching the life of George Landen Dann.

GEORGE - A Queensland playwright, in his early 70s in the scenes with Deborah, however, in other scenes he is in his mid 20 s, at which time he is quite shy and struggling to work out his identity as a writer.

DEBORAH RASMUSSEN - A bright and eager Honours student whose thesis research is about the scripts of George Landen Dann. Through visits and correspondence, they form a warm friendship and her work prompts George to reevaluate his life and collect together the ephemera of his career.

MOTHER - Mrs Dann is mother to George and two daughters, one of whom is disabled. She also has a husband she has 'given up on'.

BARBARA SISLEY - The Director of Brisbane Repertory Theatre Society, originally hailing from England and a trained actor, she is a rather grand and charismatic figure.

VOICES - These are played by the cast adopting various attitudes and perspectives as suggested by the content.

(It is possible to have doubling of characters to present the script using two female actors and one male.)

\section{Setting}

The set can be quite minimal, with chairs for the readers to sit in. 


\section{SCENE 1}

VOICE 1: George Dann? He was a refined sort of bloke, not your average Sandgate boy.

VOICE 2: He was a loner... just him and the dog. He was just one of those men who never married. We didn't think anything of it.

VOICE 3: $\quad$ He travelled a lot you know... but in Australia, he was a bit of a bushie, an early greenie too.

VOICE 2: $\quad$ He was always planning another trip, off to the Kimberleys or Thursday Island, or central Australia - out of the way places...

VOICE 1: I don't think he ever went overseas - funny really when you think of how he loved the theatre.

VOICE 2: $\quad$ You'd think he would have made a bit from all those plays, and some of them being on the TV and radio.

VOICE 3: He gave me a copy of one of his plays, not my cup of tea really. And I remember he said there was some big controversy about his first big play. Was it about the Aboriginals?

VOICE 2: $\quad$ My father said he was never the same after that scandal. I think he had a breakdown you know.

VOICE 2: Could he have made it big overseas? Interstate? Perhaps... maybe his writing would have been different if he had... it's seen as quite wordy now... but that's typical for the time.

VOICE 1: $\quad$ Did he find love? Through all the time I knew him - he never had a girl friend, but then I don't think he had a boyfriend either.

VOICE 2: $\quad$ He was stingy... or perhaps it was just that he didn't have much money ... he had this old car... he never bought a new one.

VOICE 3: He was gay you know... my father seemed to think so too, even though you didn't talk about things like that in those days.

VOICE 1: $\quad$ No, he wasn't gay, he was just one of those people who liked his own company. No... I don't think that's right.

VOICE 3: I'm sure that's why he moved away, wasn't he living with someone?

VOICE 2: $\quad$ I think he could have been really big if he'd left and gone overseas. I don't know what held him back. I think there were issues with his family earlier in life. I think he wanted to be a Minister actually. 
VOICE 1: I used to get quite a thrill to hearing some of his plays on the radio of a Sunday night. You don't think of a boy from Sandgate becoming famous, do you?

\section{SCENE 2}

RESEARCHER: Some people say that research is always autobiographical, that we are always searching to explain something to ourselves, to answer a question posed by our life history. So what do you make of this?

I've been fixated on this man. Trying to find out as much as I can about him, what makes, or made, him tick. But it's not what you think. He's been dead for nearly 40 years and may well have been gay - or latently so - he never married, never had children, was known to be a bit of a loner. So why the interest? Well part of it started with a simple coincidence about place.... he happened to die in the town where I live - Eumundi.... or so the records say.

So many questions arise for me as a researcher, as a writer - Why did he write about Aboriginal characters and islands? What powered his interest in injustice and isolation? Why did he stay in Queensland? Why didn't he go when he could? Why didn't he marry - was he gay, did he act on it, or was he constrained by religious beliefs and a fear of social ostracism? Did he experience intimacy with another human being and if not, how do you live such a life? Was he a martyr to his family or did self-doubt prevent him from making the break? And finally, what was his work like, was it any good, what can we learn from it, is it worth restoring to the public record or only of interest for research purposes?

Now Eumundi isn't that big a place, let alone a few decades ago, so I thought it was just a matter of asking at the local museum about him - did he live here, where, did anyone know him... but nobody had. Later I tracked down people who had known him, a nephew, a Coolum local, a neighbour - some of their recollections insightful, some contradictory. Dr Google told me that his papers were in a library, a two-hour drive away. There in the Fryer Library I discover the sensory joys of archival research, of photographs, of fragments, of letters and another researcher. A young woman of the 70s, Deborah Rassmussen was an Honours student at UQ. In the last year of George's life she contacted him and began her own research. What was the question she was seeking to answer?

\section{SCENE 3}

DEBORAH: November, 1976. Dear Mr Dann, You don't know me, but I believe Alrene Sykes may have recommended me to you. I am studying for an honours degree and would dearly love to focus on you and your work. I've read many of your plays and have been researching your life as one of Queensland's foremost early playwrights. I am hoping 
it might be possible for me to interview you. I can travel up to Noosa to visit you if that would be convenient. Yours most sincerely, Deborah Rassmussen.

GEORGE: Dear Deborah, Alrene had mentioned you in a letter previous to her visit with Katherine Brisbane, when your name came up. Leslie Rees also told me of a person at the university who intended to do her thesis on my work. So I practically feel I have been introduced to you already...

DEBORAH: He lived in a ramshackle wooden hut with his dog on the shores of Lake Weyba, at the end of a dirt road. He only used one room of the house and in it was a bed with a crocheted patchwork quilt, a clutter of old chairs, books, Aboriginal artefacts and a map which highlighted his journeys in Australia. He had a meal waiting for my first visit, crab salad and strawberries.

GEORGE: It's not too bad for \$2 a week is it? More than enough room for me and the dog. Good for fishing and crabbing. Fresh crab for lunch, caught it myself.

DEBORAH: Aren't I the lucky one - all the other honours students are stuck doing book research in stuffy old libraries. And here I am, about to have a homemade lunch with the award-winning playwright George Landen Dann.

GEORGE: $\quad$ You are too kind. I am humbled but pleased that you like my work.

DEBORAH: I admire the way you have approached serious subjects, the Aboriginal problem - but so much more. Are you still writing?

GEORGE: I'm an old scribbler, always was. Mother would chide me saying 'come and sit with us'. 'I'm busy' I'd call back. 'Busy with what?' she's say. 'Oh just scribbling'. And that was how I came to write the play that changed my life. Scribbling away after work in the evenings... it was my time of beauty and escape. Three months it took me to write 'In Beauty It is Finished'... keeping it a secret from everyone. Mother had no idea what I was up to. She never knew until after the official announcement was made.

DEBORAH: I've read through all the press clippings and the plays in the library. You were really quite famous weren't you?

GEORGE: Famous or infamous. Heavens, I never realized how notable I must have been - and all the time I was doing my utmost to avoid the publicity. But it still piled up around me despite my attempts. I never expected the scandal... it didn't go down well at home either.

\section{SCENE 4}


MOTHER: He should be home by now. He's always home by $6.00 \mathrm{pm}$. There's something going on, some secret. What on earth could he be up to? Running around with these fancy theatre people, I wonder what they've convinced him to do this time. Or maybe he's met someone, he's finally found a girlfriend. I just know there's some secret he's been keeping from us? (As if hearing something outside) George, is that you?

GEORGE: Don't worry Mother, there's no wild women or weddings on the horizon. I've been out at the theatre.

MOTHER: Getting silly ideas in your head yet again at that theatre. You need to forget about those fancy dreams and just get on with your life. You've got a good secure job now. You're luckier than most these days.

GEORGE: I am, that's true. But I have been keeping a secret and now I can let you in on it. I just saw the play 'Yellow Sands' with the Brisbane Repertory Society and afterwards they made a special announcement.

MOTHER: What is it then? Spit it out?

GEORGE: I've won a playwriting competition. An important one too, the Brisbane Repertory Theatre Society's award for best new Australian play. They picked my play over nearly 100 other entries.

MOTHER: Is that right? And what have you won then? A prize ham?

GEORGE: No, I've won 50 guineas. And they're going to stage my play as well. At His Majesty's Theatre, holds over one thousand patrons. And Miss Barbara Sisley from the Brisbane Repertory is going to produce it herself.

MOTHER: That so, is it? And when did all this come about?

GEORGE: I wrote it a few months ago. I'm sorry Mother, but I didn't want to tell you until after it was official. Just in case they changed their minds. But casting and rehearsals begin next week. It's really happening, this is my big break Mother.

MOTHER: $\quad$ So you can do what? Leave your job, run off to Sydney. Leave me here with a useless husband, a sick daughter and no way to pay our way. Just as long as you're happy George, don't think about us, will you.

\section{SCENE 5}

RESEARCHER: While dramatic scripts might have turning points and defining moments, do most of us have them in real life, do we recognise them when they occur and are the impacts so easy to identify? I can't say 
that for me any single event stands out as such, but I think one did for George Landen Dann with 'In Beauty It is Finished'.

I read the play, wondering if it was still worthy of interest today beyond being noted as one of the first plays to feature Aboriginal characters - albeit played by white actors 'blacked up'. It's not bad, though the treatment of the Aboriginal mother in particular is cringeworthy. His characters are by a sense of duty but also by place, inspired by the family who lived at the lighthouse on Moreton Island. In the play, a lighthouse-keeper's two daughters take turns living on the island to keep their mother company. The controversy surrounding the play centres on one of the daughters, Marion, who has been earning her living as a prostitute while in the city. Back on the island she begins a relationship with a man named Tom. While initially unimpressed by fact he lives with an older Aboriginal woman, Marion is horrified to discover that he is the son of that woman and is - forgive me for saying it - a 'half-caste'. After her father has a meltdown when he discovers the relationship, Marion escapes with Tom, but the tone is tragic rather than triumphant.

Before the show opened rumours began to circulate that the play contained highly 'sordid' content and the local publication Smith's Weekly requested a copy of the play. The subsequent article sparked citywide interest and one of Brisbane's most famous theatre controversies.

VOICE 1: 4 July 1931 Smith's Weekly - 50-pound prize awarded to a filthy play - a sordid drama of miscegenation.

VOICE 2: $\quad$ The title 'In Beauty It is Finished' is totally misleading. The story is a sordid and soiled one of the most dubious romance of a selfconfessed woman of the streets and... a half-caste.

VOICE 1: $\quad$ The Repertory Society must explain how it came to accept this disgusting and unwholesome story for presentation.

VOICE 2: $\quad$ There are terms and expressions in the script that cut across the accepted traditions of the stage, and reach new depths in the sordid.

VOICE 1: The whole story, in its exposure of the most degrading aspect of sex, must strike a chord of disgust in the hearts of those who respect Queensland womanhood.

VOICE 2: $\quad$ Such a lack of beauty is evident in its outlook that the title is a total travesty.

VOICE 1: The Brisbane Repertory Society seems likely to be rent in twain and can likely expect a swooping visit from the censors either during the performance itself or immediately afterwards. 
VOICE 2: $\quad$ With so much discussion in the air everyone is deeply interested, and for the opening-performance a record audience is promised. Next week you'll hear what the verdict is.

\section{SCENE 6}

BARBARA: Well George, there's been quite a shindig about your play.

GEORGE: Oh Barbara, I'm so terribly sorry about what has happened.

BARBARA: We'll ride the storm out with you George. Hold your head high.

GEORGE: But have you seen this morning's paper? More letters, some are demanding the play be banned. Sermons are being preached against me. I've had to change the route I take to work, walking the back streets to avoid fuss and attention. And Smith's Weekly keep adding fuel to the fire.

BARBARA: Terribly insincere lot these people from Smith's Weekly. They contacted me and requested a copy of the script for their perusal. They said it was to help provide some additional publicity for the production. I didn't quite anticipate the exact nature of that publicity.

GEORGE: $\quad$ Barbara.... I have to say ... I understand if you think it best not to proceed. I won't sully the good name of the Society.

BARBARA: The board will stand by us.

GEORGE: But what if people aren't ready to see this reality on stage?

BARBARA: George this is an important play. You are an important new writer. Don't doubt yourself now.

GEORGE: I feel eyes on me at every turn. I've had people whispering and pointing as I catch the train in the mornings. Maybe I should stay at my desk, stay with what is safe, hide behind order and reason.

BARBARA: What nonsense George. We can't shy away from a little bit of controversy.

GEORGE: But what about these rumours of censors, of bans and police?

BARBARA: Well it will be a first for Queensland if they do George, and just think of the headlines. So dust off your suit and prepare your victory speech George. This show will go on.

\section{SCENE 7}

VOICE 1: $\quad$ (Reading newspaper clippings) July 11 - Jottings in The

Truth. London theatre managers long ago discovered that the success 
of practically any play was assured if it was attacked violently enough by press and pulpit. The rumour has gone around that this play is 'strong meat' ... public interest is quite unprecedented, and there are sure to be bumper houses when the curtain rises.

VOICE 2: 17 July 1931. The acting was good. Miss Scott was excellent, and Edith Rowett as the old gin was amusingly native.

VOICE 1: July 17, The Patriot - Despite the excellent acting and good staging, it is rather a pity that the half-caste question should be placed in the limelight. This is a country advocating a White Australia Policy, and reference to our darker tragedies is a bad advertisement abroad.

VOICE 2: 18 July 1931 - To a certain extent one felt pity for the main character, but of horror there was none. Not even a convenient suicide.

\section{SCENE 8}

RESEARCHER: It's about six months since I first applied for permission to copy some of George Landen Dann's manuscripts and documents that are held at the Fryer Library. I can still recall the look on the librarian's face when I handed in the forms.

LIBRARIAN: Oh, I hope you aren't in a hurry.

RESEARCHER: Not particularly, but your form mentions it might take a week to 10 days.

LIBRARIAN: That all depends. It depends on how straight forward it is, who we have to get permission from. For the Dann materials I believe it often takes many months.

RESEARCHER: Why is that? He never married or had children. What is the problem?

LIBRARIAN: Well, there is a major organisation involved but they aren't the sole copyright owners. We'll have to send the application through to the public trustees office, I don't know what the situation was with his family.

RESEARCHER: So began several months of me waiting patiently.... Hoping to get that email telling me it was all clear to copy away... but it didn't come. That is when my researcher as detective work truly began.

Through the wonders of Trove digitalised newspapers I had discovered that George's sister Dorothy married Viv Livingstone from Bellthorpe. They had lived in Woodford and had two children. They went through a rather nasty divorce in 1948 but it seemed likely to me that by 1977, when George had died, that she or the children had still been alive. 
Now here's where hunches and following the scent takes over ... my family grew up in the Caboolture area. I asked some of them if they recalled any Livingstones from the Woodford and Bellthorpe area and one did ... she then put me on to her friend who had actually lived in Bellthorpe. Within an hour, I had a name and also the phone number of Grahame - George's nephew and sole living family member quite a breakthrough! Grahame was more than happy to chat to me on the phone, and then I was able to meet with him and discuss a little more of what he could recall of his Uncle George! Grahame is a friendly, open man who shares George's love of travelling the Australian countryside, camping and the bush. He freely admits though that he is no arts or theatre type and didn't know that much about what his uncle had written.

RESEARCHER: $\quad$ So Grahame can you tell me what the situation is with permissions to use George's work? Why is it so difficult? Did he have a will?

GRAHAME: Oh yes, he had a will, he rewrote it quite a few times, we were in it Mum and I - at one stage. I think in the last one he pretty much left the lot to the MacMinns.

RESEARCHER: And how did you feel about that?

GRAHAME: Neither Mum nor I were theatre types. The MacMinns, well they were. They let us take whatever we liked. Mum took Uncle George's tele I think. It was all very friendly. He didn't have much of value and he was very fond of Gwen - Mrs MacMinn that was.

RESEARCHER: She had been on the board at LaBoite I think.

GRAHAME: Yes she was one of his old theatre buddies. George probably thought she'd be better off looking after his plays than someone like me. I was a truck driver after all. There wasn't much else of value he left behind. He didn't even own that house he lived in down on the lake.

RESEARCHER: I followed George's footsteps, stood underneath the Lake Weyba mango trees, the house long gone. Drawn to the lake's edge and down into its shallows.

I can understand why George escaped to these places to sooth his soul; with nature being one way he created a beautiful space to retreat to. The other being writing... an escape from a life of family obligation and suffocating small town thinking. A sister who was an invalid, a father who was invisible and a mother who, if you examine most of the mother figures he created, was something of a monster. He would escape periodically, often off to an island. Fraser Island, Hamilton Island, far away from obligation and regulation. A diary entry begins one such journey - 7 April 1932. 


\section{SCENE 9}

GEORGE: Well Barbara, I have an announcement to make.

BARBARA: Bravo George, Fire away.

GEORGE: I've quit my job. I'm packing a bag and I'm leaving Monday.

BARBARA: How wonderful, where for George? Sydney, Melbourne?

GEORGE: No.

BARBARA: New York, London?

GEORGE: $\quad$ You'll never guess... an island... an island paradise - Hamilton Island

BARBARA: Oh ...

GEORGE: My dream life. I'm going to escape, leave society and all it's rules and restrictions. I want to live with nature, to exist, to think, to write and be free.

\section{BARBARA: That's quite a dream George.}

GEORGE: $\quad$ Yes it is isn't it? I'll fish from the seas and live from the land. What we collect and grow we'll eat and in the evenings, I'll write whatever and whenever I choose, in touch with the wisdoms of the universe.

BARBARA: That sounds quite wonderful dear. I only wish I could come with you? How long to do you think you'll be gone?

GEORGE: As long as possible, forever, a year, who knows?

BARBARA: Have you thought about travel overseas George? I still have contacts in London, I can send them your work. I think there would be interest in this new voice from the colonies. I might even venture back myself if you care to wait.

GEORGE: London. Perhaps, maybe... later... if I feel the call to return to civilization and her laws I'll let you know. But not now. I have to escape Barbara. I have to find my island... my freedom.

\section{SCENE 10}

GEORGE: May 1932. I can't write. Nothing. I sit, I drift. Ideas stagnate and die. This life, this drifting, this nothingness. It's rotting my mind, rotting my system. Damn my glorious expectations, damn my foolish dreams of success and freedom. 
Twelve months ago - to the very day - I became, to a certain extent famous. Famous for writing a play and having it produced. It caused a sensation, sent my mind whirling and thinking I could be someone. But it got you nowhere. It had but one effect. It had you basking in a sun of imaginary glory. But now the glory has faded, and you've faded with it. The dream bubble has burst, filled up with hot air from literary people, amateur actors and the intelligensia. You were fool enough to think they meant what they told you. It was nothing. Absolutely nothing. Twelve months of dreaming.

It's time to forget the glorious expectations. It's time to wake up, bloody fool! You're not a writer - you never will be. You're nothing you never will be anything - only a rotten failure. What hopes, what dreams. From now on I'm going to be an ordinary common individual like the thousands of other common individuals in the world. I'm going to come down from my ladder pointing to the stars and I'm going to roll about in the mud and dust.... to be a common place miserable ordinary individual of the world. And I've got a feeling I might even like it quite a lot.

\section{SCENE 11}

DEBORAH: So after your Hamilton experience you went back to Brisbane, an office job and thought you would never write again. But you did of course. Did it take long before you come back to writing?

GEORGE: Not at all, isolation, suffocating family life. It's all there in my play 'Oh, the Brave Music'. It was ironic really. When I had the freedom I'd craved and all the time in the world to write, I didn't, I couldn't. Once I'd returned to something more familiar, I couldn't stop myself. The fragments of experiences and people I met formed voices in my head, characters calling out, their stories tumbled onto the page.

DEBORAH: And you had a lot of success after that. Won all those competitions, had your work performed in most Australian states, in Wales, in London, on national radio and Ring Out Wild Bells was converted for television. Then plays published, Fountains Beyond, Caroline Chisholm, which I understand was almost made into a film. But you still didn't move to the big city centres, go overseas? Your home base Brisbane, then Coolum, building your house overlooking the sea. Why was that?

GEORGE: I had the family to provide for, and then later, when I could leave, I'd lost the need to prove myself in that way. I wanted to explore the hidden stories and places of our land. But Deborah what about you? Are you going to escape, to travel, to write - how about writing a play of your own? 
DEBORAH: I'm not sure yet. I was going to go straight into work or more study, but I have a chance to go to London and Paris with a friend, and I think I may just take it.

GEORGE: If you want my advice Deborah ... Do it, seize on all the opportunities you can, they don't come too frequently. By the way I have some news of my own.

DEBORAH: Have you been back writing?

GEORGE: I have been working on a novel actually. But the latest news is about 'In Beauty'. They want to re-stage it to honour my friend and mentor Barbara Sisley. They've finally agreed on a way to remember her. There's to be a clock in the new La Boite Theatre, and a restaging of Beauty. It's a season full of Queensland only plays, and I'm happy to say they're keen to promote more Australian work.

DEBORAH: Well that is the most wonderful news George. I do hope I'm here to see it.

GEORGE: Would you be my guest at the performance? There's to be two opening nights. I've been invited to present a speech in her honour at one of them. I'd love for you to come with me.

\section{SCENE 12}

RESEARCHER: $\quad$ And so it was ... His first major play, In Beauty It Is Finished, was the last performed in his lifetime. It was staged in March 1977 just three months before his death.

Performed in the intimate space of the La Boite Hale St theatre, Sydney critic Katharine Brisbane was there and reported the surprise of audiences who were awestruck by the emotion of the drama.

VOICE 1: $\quad$ After 45 years of hibernation, George Landen Dann's dark drama of isolation in the deep north, In Beauty it is Finished, has taken its audience totally by surprise.

RESEARCHER: $\quad$ Brisbane actor Dianne Eden performed in the 1977 production as Marion and recalls the effect the play had on the audiences as...

VOICE 2: $\quad$... electrifying, a black man making love to a white woman! Joe Woodward [who played Tom] wasn't Indigenous of course but he had black hair. It shocked and surprised people. It was a very passionate play. And it was Australian and not British, a different kind of Australian play, not ocker but iconic in a new way.

RESEARCHER: The personal conflicts and interpersonal relationships at the heart of the drama still rang true. He had touched a new audience. And so his story and his work came full circle. 
A few months before he died Deborah sent her Honours dissertation to George. On the shores of Lake Weybe he read it immediately and in his letter to her records how terribly moved he was after the reading ...

\section{SCENE 13}

GEORGE: Dear Deborah, The copy of your thesis arrived today. Naturally, I opened the package at once and read and read. Don't conclude from what I am about to tell you that I'm senile, decrepit, over-emotional and childish, but my eyes began to swim and I could scarcely contain my tears. So I walked in a daze down to the Lake and sat on the edge. And then I couldn't bottle up my emotion - I really did burst into tears.

DEBORAH: If by now you have become alarmed by thinking I was annoyed, angry and disappointed, you can put an end to your fears right now. The "matter" with me was that I was so over-joyed for you for having done such an excellent job on your thesis and so very grateful to you for having done it.

GEORGE: Debbie! Your thesis is WONDERFUL. It far exceeds what I expected - and I did expect a great deal of you from the start. With every once of sincerity in me - and with a very deep feeling of humility I thank you very, very much. I find I really cannot express in words my appreciation as adequately as I would like to - but be assured I am very grateful to you. ....

DEBORAH: Life and Death, death and struggle, death and beauty... What do people leave behind? Beauty? "Not dust to dust, not ashes to ashes, Nay. Beauty... only in beauty passes away". But people also leave their names.

GEORGE: And so I must reveal my humble ambition, I've never told anyone before - and it is this ... I always hoped that my works would live on, that my name would live after I died and not die while I lived...

Your thesis will put me into history Deborah - and for that and all you have done for me I thank you very much indeed.

\section{SCENE 14}

RESEARCHER: I found the MacMinns, I gave the library their contact details. I wrote the forewords for four of George's plays, which have now been published and available to new audiences. And this record, this text, this new audience now realises George's humble ambitions and perhaps some of my own. My questions to George - some answered, some not. His story posing questions for my story - questions of partially realised potential, overcoming constraints and insecurities, finding a way to exist with art and realities. He, the talented 
Queenslander who achieved so much, but probably could have achieved more ... is that what resonates for me, for others? To see our names, our work to live on? To find moments of beauty, of contentment and even, of grace?

I return to the water's edge, a place not so far from where I live. A connection, some understanding.

I stand within a gentle blueness, it's pale expanse opens up before me. I feel like I could open my wings and glide From water to air and sky Floating over and across the land and towards the heavens. The water's lapping lullaby joined by A melody of bird cries and songs A chosen present Matters as much as what might remain That, perhaps an answer to my questions - questions to George.

THE END 


\section{Research statement}

\section{Research background}

This script investigates dramatic questions and theatre history through the creative form of a Reader's Theatre script (Donmoyer 2008) in a documentary style. It draws on archival evidence, the work of an earlier researcher (Rasmussen, in Dann 1976-77) and the writer's own empirical research and creative experimentation.

\section{Research contribution}

The work combines theatre historiography and creative practice to contribute to the writing of history honouring the legacy of a major Australian playwright through an appropriate creative form - that of a script. It also extends upon an investigation of ways that research may be embodied through creative practice.

\section{Research significance}

This work uses the dramatic form to encapsulate research that is both emic and etic in nature, questioning the creative process and the writer's legacy through a focus on researching a significant Australian playwright. The researcher is present in the process and the text, invigorating historical content in a reflective dramatic form. It complements the recent publication of Dann's scripts for Playlab's New Vintage series to ensure his work and name gain wider contemporary recognition.

\section{Works cited}

Brisbane, K 1977 ‘An Australian Strindberg’ The Bulletin 99.5055, 65-6

Dann, G L 2012 In beauty it is finished Playlab P, Brisbane

Dann, G L 1976-7 Letters, 1976-1977: Noosaville, to Deborah Rasmussen (F2484), Fryer Library, U of Queensland

Donmoyer, R 2008 'Readers theater' in Lisa M Given (ed) The Sage encyclopedia of qualitative research methods Sage, Thousand Oaks CA, 731-32

McCallum, J 2009 Belonging: Australian playwriting in the 20th century Currency, Sydney

Rees, L 1973 The making of Australian drama Angus \& Robertson, Sydney

Rowbotham, D 1962 'The One Day of the Year: book review’ The Courier Mail (copy sighted) 


\title{
Curtin University
}

\author{
Kath Dooley
}

\section{Night bus: a short drama script}

\begin{abstract}
:
Night bus is a creative exploration of relationship between the screenplay, affect and bodies. The short film script sees a re-imagining of contemporary, real life events to produce a dramatic narrative concerned with themes of public violence, individual intervention and responsibility. Following on from research into the affective dimensions of cinema, this has been written as a means to explore the conditions that encourage the production of bodily sensation at a conscious and unconscious level within the screenplay itself. I have sought an answer to the question of how the screenwriter's description of material gives rise to a visceral response in the reader, which may also be reflected in a resulting film text. My screenwriting focuses on the creative use of narrative content and the description of aesthetic dimensions such as colour, light, sound, movement, rhythm and texture to affect the reader.
\end{abstract}

\section{Biographical note:}

Dr Kath Dooley is a filmmaker and academic in the Department of Film, Television and Screen Arts at Curtin University, Western Australia. She recently completed a creative $\mathrm{PhD}$ exploring portrayals of the body in the work of contemporary French directors Claire Denis, Catherine Breillat and Marina de Van at Flinders University, South Australia. Kath has written a number of short and feature length screenplays, and has also directed several award winning short films and music videos. Her current research interests include film production methodology and screenwriting in Australia and France.

Keywords:

Creative Writing - Screenwriting - Short drama - Affect 


\section{Night bus: a short drama script}

\section{The Characters}

KELLY - An intelligent, well-educated, young professional.

TOM - Kelly's boyfriend.

CHANTAL - An aggressive and attention-seeking teenager.

KRYSTAL - Chantal's impulsive and irresponsible accomplice.

BUS DRIVER

\section{VARIOUS PASSENGERS}

\section{Setting}

Adelaide, South Australia, present day. 


\title{
NIGHT BUS
}

FADE IN :

1. EXT. CITY STREET - EVENING

Tall buildings cast thick, dark shadows onto wet pavement. Slow moving traffic and random pedestrians in casual evening dress move by as KELLY (28) and TOM (30), a casually dressed couple, stroll side by side. Overhanging roadside trees rustle in the wind. Kelly stuffs cold hands into her jean pockets.

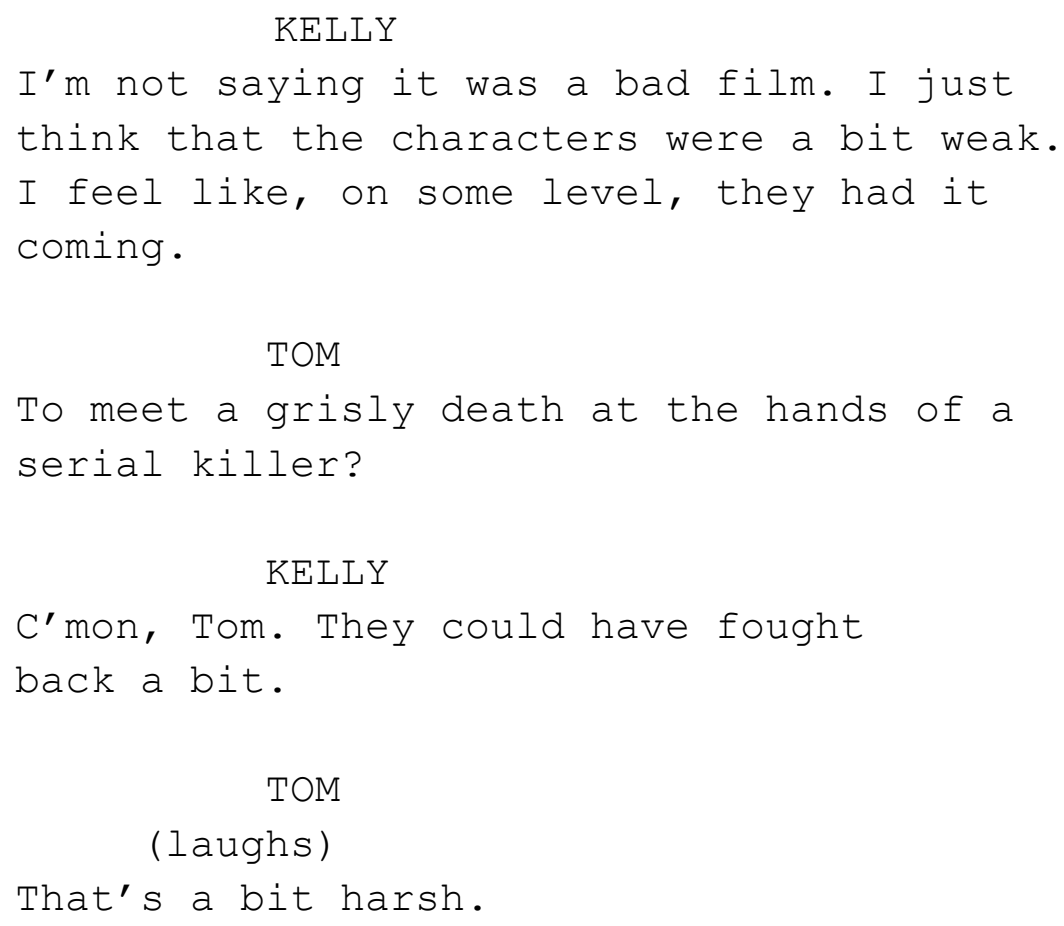

They arrive at a bus stop. TWO OTHER COMMUTERS stand waiting nearby, their eyes on mobile phone devices.

Kelly stares at the bright red tail lights of passing cars.

TOM

I thought it was good. Plenty of action, good story...

\author{
KELLY \\ Plenty of hot chicks...
}

Tom smiles and playfully hugs Kelly.

A bus arrives at the bus stop, hissing as it pulls to a halt. 
ROLL TITLE: 'NIGHT BUS'

CUT TO:

2. INT. BUS - NIGHT

We hear a steady thump-thump as the bus powers forward over uneven asphalt. The moving bus harbours a handful of dreary and silent passengers, whose reflections stare back at them in dark windows. Fluorescent lights buzz overhead and a generic commercial radio pop track plays from hidden speakers. Flashes of light stream past from outside as the bus hums along.

AN ELDERLY MAN with a walking stick sits quietly, reading, at the front of the bus.

A WOMAN in her fifties sits with eyes closed in a seat behind him. She rubs her face, tired.

TWO MEN in their forties sit and chat quietly further back.

Two lone LATE TEENS have their attention on mobile phone devices in the middle section of the bus.

Kelly sits aside the aisle, next to Tom (who is at the window), towards the rear of the bus.

She stares at her tired reflection in a nearby window, and yawns.

Kelly massages the back of her neck with one hand.

She notices a drip of water moving down the wall at Tom's side. The roof has a small leak.

Tom drops his head onto Kelly's shoulder. He is also tired. The thump-thump sound slows in pace. 
3. EXT. BUS - NIGHT

The bus pulls to the side of the road with a screech. The rear orange indicator light blinks on and off so that red neon light reflects on wet bitumen nearby. We hear the sounds of late night city traffic, nearby club beats and the hum of the now stationary bus' steaming motor.

CUT TO:

4. INT. BUS - NIGHT

The front door of the bus is open. CHANTAL (18) and KRYSTAL (17) stumble on board, unsteady, inebriated. They wear short, tight dresses and extremely high platform heels. Chantal staggers forward, with Krystal behind her.

\author{
CHANTAL \\ (mutters) \\ Give me my ticket.
}

Krystal is searching for tickets in a handbag.

Kelly watches. Tom stirs. He checks the girls out, interested.

Kelly notices Tom looking and frowns at him. Tom shuts his eyes and returns his head to Kelly's shoulder.

Chantal grabs a ticket from Krystal's hand.

The MALE BUS DRIVER (25) stares at Krystal.

She notices and in response, presses herself against the plastic wall that separates him from his passengers.

KRYSTAL

Take a photo!

The bus driver looks away.

Krystal chuckles to herself. 
The front doors snap shut and the bus returns to motion.

Kelly returns her gaze to the side window. The thump-thump noise starts once more.

The drip of water has moved down to the floor nearby, where a small pool of liquid is forming.

Tom moves his head close to the glass and exhales a strong, warm breath. The glass fogs. He uses his finger tip to draw a smiley face, but then he changes the smile to a frown.

Tom looks to Kelly, who mimics the crudely drawn expression on her own face for a moment, then lets it go. Tom smiles back and they both relax into the shaking movement of the bus.

Suddenly there is a loud noise- a bottle hitting the ground.

Kelly and Tom stir and look to the front of the bus.

Krystal has thrown an empty alco-pop bottle in the baggage hold. It rolls around noisily. Chantal is angry.

\section{CHANTAL}

I told you to leave me some, you cow!

Krystal laughs and starts to swing from the bus' overhead bars.

Chantal loses one of her shoes as the bus jerks without warning.

CHANTAL

$$
\text { (yells) }
$$

Nice driving!

The anxious eyes of the bus driver can be seen in the rear view mirror. He makes eye contact with Kelly in the mirror for a moment.

Various bus commuters glimpse at the girls, unsettled. 
The women in her fifties clutches the metal railing at her side.

Kelly rubs her hand over the coarse fabric of her jeans as she and Tom watch. The thump-thump noise quickens as the bus picks up speed.

Chantal is clumsily trying to slip her shoe back onto her foot.

\title{
CHANTAL
}

(To Krystal)

These shoes suck!

The elderly man lowers his book.

$$
\begin{aligned}
& \text { ELDERLY MAN } \\
& \text { Keep your voices down. }
\end{aligned}
$$

Chantal and Krystal look at him with disdain.

$$
\text { CHANTAL }
$$

What did you say?

\author{
ELDERLY MAN \\ It's rude. Keep your voices down.
}

Chantal and Krystal exchange a somewhat amused look. Chantal hunches over the man, invading his space.

CHANTAL

What's that old man?

ELDERLY MAN

Try to act like ladies.

Chantal looks at Krystal and scoffs. She leans down and knocks the man's book out of his hands.

The thumping noise speeds up as the bus continues to accelerate. The man reaches for his book but Chantal kicks it further away, towards Krystal, who reaches down unsteadily to pick it up. 
Kelly and Tom exchange a concerned glance.

\author{
ELDERLY MAN \\ Give that back!
}

Krystal laughs, and then throws it at the man. He flinches and gasps as it hits him in the face.

Krystal and Chantal laugh.

Kelly recoils, shocked.

Other commuters glance around the bus, anxious.

The bus driver's scared eyes check the passing events in the rear view mirror, but the bus continues to move forward.

The elderly man rises from his seat. His shaking hand clutches the walking stick. He reaches out for the nearby Chantal, who pushes him aggressively. He falls back into his seat.

Chantal looks about the bus, outraged.

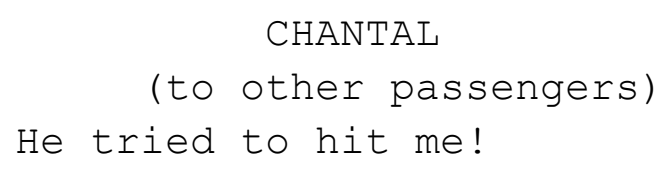

Nearby passengers avoid Chantal's gaze.

Chantal moves forward and slaps the man on his shoulder.

Krystal moves forward and joins in.

KRYSTAL

You can't touch us!

ELDERLY MAN

Get away!

He swipes back at the girls.

Kelly looks around the bus. She turns to Tom. 


\section{KELLY \\ Somebody needs to stop them!}

Tom is conflicted.

TOM

They're dangerous. Just leave it.

Chantal and Krystal repeatedly slap the man, cursing and yelling. The man tries to defend himself but fails.

Kelly is appalled. She stands up and makes a move down the aisle. Then Tom pulls her back.

TOM

$$
\text { Don't! }
$$

Tom makes a move forward in her place, approaching the wild girls.

His footing is slow but firm as he advances, this movement irregular against the steady thump-thump of the bus.

Other commuters stare as he passes and reaches the front section.

TOM

Leave him alone!

The girls continue with the attack, which is becoming increasingly aggressive.

Tom moves between the man and the girls. We hear the squeal of brakes as the bus slows, and the hissing of the engine. All passengers jerk to one side.

Kelly watches, holding her breath.

Chantal looks at Tom with aggression.

$$
\text { CHANTAL }
$$

Get away!

There is a moment of stillness of bodies. 
The hissing of the engine grows louder. Then Krystal punches Tom in the face, hard. He gasps and recoils. Blood trickles from his nose.

Chantal pulls Krystal towards her.

CHANTAL

We'll sue you. You can't touch us!

Tom staggers across the aisle, clutching his face.

Kelly jumps to her feet and races forward. The bus lurches to the side of the road.

Other commuters stare as she approaches the girls.

\author{
KELLY \\ (fierce) \\ Get off the bus!
}

She puts herself between the girls and the elderly man.

Tom wipes his bleeding nose with the back of his hand.

Krystal smirks at him, amused, with an excited look in her eyes.

Chantal raises her hand to push Kelly away, but Kelly grabs it and twists her arm.

CHANTAL

Ow! You're hurting me!

The front doors open.

$$
\text { KELLY }
$$

Get off!

CHANTAL

(hysterical)

stop it! You're hurting me! 
Kelly turns and notices one of the nearby YOUNG PASSENGERS is filming the altercation on his mobile phone.

Kelly releases Chantal's arm and takes a step back.

\author{
KELLY \\ (to the passenger) \\ Turn that off!
}

CHANTAL

(crying now)

That's assault!

The driver opens his compartment and takes a step out.

CHANTAL

That's assault you bitch!

Chantal and Krystal retreat towards the front door but then Krystal takes a step forward to kick the driver's plastic barrier.

\title{
KELLY
}

Get off!

CHANTAL (to Krystal)

$C^{\prime} \operatorname{mon}$.

The girls stagger off into the darkness outside the bus, cursing. We hear the amplified sounds of passing traffic outside.

Kelly moves back. She picks up the elderly man's book and returns it to him.

Tom rests against a seat nearby. Kelly clutches him and examines his bruised, blood-smeared face.

She turns to look at the other bus commuters. Some of them meet her gaze, while others look away.

CUT TO: 


\section{MOMENTS LATER}

Kelly and Tom sit together, more tired, and recovering from the ordeal. The pop background music continues, as do the dull screeches of the moving bus, and the repetitive thump-thump of tyres on asphalt.

The steady trickle of water has now passed underneath their wet feet and into the aisle of the bus.

Suddenly we hear the recorded sound of commotion coming from a nearby mobile device.

Kelly looks about. She recognises the sounds-it is the fight that has just happened. Her own words ring out. The source is a mobile phone belonging to the teenage boy who sits a few seats forward.

Kelly rises and approaches the teenager.

An annoyed Tom looks on.

Kelly looks over the teenager's shoulder to see images of herself and the two wild girls.

\section{KELLY}

Delete it.

The teenager pauses.

KELLY

(more aggressive)

Delete it!

The teenager recoils, scared.

\section{TEENAGER}

Okay •

He hurriedly deletes the file.

Kelly returns to her seat and dumps herself down next to Tom. The pair exchange a long gaze. Kelly runs her hand down the 
side of Tom's injured face. The thump-thump sound accelerates as the bus powers forward.

FADE TO BLACK

END OF SCRIPT 


\section{Research statement}

\section{Research background}

Writers from a variety of backgrounds (Shaviro 1993, Sobchack 2004) have considered how cinema affects the viewer on a bodily level. For MacDougall, films appeal in a 'direct way to the human sensorium, in part because of the senses they address' (2006: 57), while for Marks, films call upon the viewer's traumatic and everyday experience to 'evacuate memories from objects' (200: 77). Night Bus draws upon this research to consider the relationship between the individual body of the reader/viewer and the screenplay. The script explores themes of public violence and individual responsibility in a contemporary and familiar setting. Within this I have sought to explore how descriptions of action might arouse corporeal reactions of fear, pleasure and/or disgust in the reader, drawing upon their own experience of public violence.

\section{Research contribution}

Night Bus investigates the application of concepts related to the embodied viewing of film texts to the screenplay text. Academic arguments presented by writers cited above have been explored in creative form through the writing of action and dialogue. New knowledge can be found in the script's narrative content and description of aesthetic dimensions such as colour, light, sound, movement, rhythm and texture, which are utilised to trigger certain bodily responses in the reader/viewer.

\section{Research significance}

This script questions how the screenplay, as opposed to the completed film, might draw upon the reader's own bodily experience as a means to increase engagement with its themes. I explore how the use of language within the realm of signification and representation can engage the reader on a visceral level. The script is a wholly original creative work that stands as evidence of the creative exploration of scholarly ideas related to cinema and affect.

\section{Works cited}

MacDougall, D 2006 The corporeal image: film, ethnography, and the senses Princeton UP, Princeton, NJ

Marks, L 2000 The skin of the film: intercultural cinema, embodiment, and the senses Duke UP, Durham, NC

Shaviro, S 1993 The cinematic body U of Minnesota P Minneapolis

Sobchack, V 2004 Carnal thoughts: embodiment and moving image culture U of California P, Berkeley 


\title{
Monash University
}

\author{
Anne M Harris
}

\section{Lola in the Bathtub}

\begin{abstract}
:
Lola's a woman on the edge. In fact, she's gone over the edge, but she's not quite sure where she's landed. It could be the Hudson River, off the edge of Manhattan, or it might be considerably further. The only thing that's clear is that nothing will ever be the same again. A foiled suicide attempt? Or the beginning of a slow bathtub to Australia? Leaving the familiar may not be as easy as it looks, but Lola's going to give it a hell of a try. This work brings together writing for performance and feminist solo performance as political and personal works of transgression in both academic and artistic terms. It's textual body as a script is a fully-realised work of creative writing, and its prior (and potentially future) life as a performance bluerprint reminds readers of the dual nature of writing for performance, and of research creation - itself a deeply personal and creative act.
\end{abstract}

Biographical note:

Anne Harris is a senior lecturer in the Faculty of Education at Monash University and works primarily in the areas of creativity, diversity, performance and digital media. She has worked professionally as a playwright, teaching artist and journalist in the USA and Australia. She has written and edited multiple articles and books that address the arts, culture, and performance. She is a co-editor of the journal Australasian Review of African Studies, arts based education editor of the journal Curriculum and Pedagogy and is on the editorial board of the journal Departures in Critical Qualitative Research and a number of book series. She is currently a fulltime research fellow funded by an Australian Research Council Discovery Award (2014-2016) researching the commodification of creativity.

Keywords:

Creative writing - Playwriting - Writing for performance - Solo performance 


\title{
Lola in the bathtub
}

\author{
Character
}

LOLA - 43, American

\section{Setting}

A bathtub-boat sits on red sand. Behind, a screen hangs onto which projections are seen. The play takes place over one rising and setting of the sun, on the Pacific Ocean. 


\section{SECTION 1 - dusk}

(Sounds of waves lapping. LOLA perches on the downstage lip of the bathtub, like she is flying. Blinding light, scorching sun. LOLA screams.

BLACKOUT.)

LOLA

Goddamnit!

(Lights ups. She finds herself face down in a bathtub. She holds her nose as though she's broken it. Pinches it if she can, tries to stop bleeding.)

If there's one thing I hate, it's the sight of my own blood. I've never liked red.

*

Nobody ever tells you - when you're about to step off the edge of the world (rubs her limbs)

That it may not work.

That you may wake up floating in New York Harbour with the rest of the garbage.

That something in you, Life, or instinct, or distaste for garbage....

May cause your arms to thrash, your legs to churn, your spirit to cling to the nearest thing to life you can find.

Sometimes it's a bathtub.

(re her arm, or her nose)

God, I think I've broken it. That would be so me.

I finally decide to take the big plunge

To end it all

To dissolve back into the watery whatever of being

Personless

The final frontier.

I mean, I finally JUMPED.

And what happens?

Face first down into a discarded bathtub floating in the

Hudson River off pier 14:

Story a my life.

I mean, in this day and age,

Somebody should warn you about the possibilities.

That the only thing you'll hear is waves

and fear

and regret.

That you might have to open your eyes again

and you won't recognize anything

Not even yourself. 
But you won't be dead. Dead never comes.

It's too old fashioned.

I have this recurring dream:

I'm standing on the pier, waving at

Roger as he swims away with this beautiful young

Albino girl.

They are both dolphins. I mean, actually, they were both

dressed as dolphins.

They look funny, but kind of kinky at the same time.

They start to have sex, and I just stand there waving them off.

I don't mind, in the dream I mean, I don't mind that they're having sex

(everyone has sex, even husbands sometimes)

but I do mind that they're swimming away, leaving me.

Then I start to wonder how dolphins really do

have sex, and when I look back again, he's gone.

They're both gone.

One afternoon

instead of going to the laundromat

I was walking down $8^{\text {th }}$ avenue, and I just...

I didn't think about it.

I didn't say to myself "Pick up the washing, or suicide?"

I just...walked along listening to my iPod

And suddenly I was on the edge of Pier 14

And suddenly I was out.

Over the edge.

Falling.

(rest. Time passes.)

*

I've been drifting for ten days now.

Which is a long time when you didn't even pack a bag.

But nobody questions how Jonah could breathe in the belly of the whale,

do they?

They just...believe.

So.

I'm drifting and I'm thinking about all the wasted time I spent on diets. And after having not eaten now for ten days, I feel great.

I feel like I've finally found a diet that works.

I've calculated that I was probably on a diet for 39 of my 43 years.

And I was still a fat pig when I jumped.

Which is probably what saved my life.

The padding.

*

I couldn't survive in that place anymore.

It's not just Roger. It's the...uber Roger. The whole package. 
The rub of being American these days.

It's not like it used to be, you've got to have an edge.

And me? I've lost my edge. I don't know when,

I don't know where it went. But somewhere here inside these

Hundred and sixty pounds of...nerve endings....

My edge just got duller and duller and duller and then

disappeared altogether.

I won't go back. I can pull the plug at any time, can't I?

but i'm not going back to new york.

come hell or high water.

which actually, now that $i$ think of it,

may very well come on a journey like this,

although i've been mercifully free of high water until now.

You never know what tomorrow will bring.

(rest.)

What really bugs me is that no one even tried to stop me.

You'd think a woman in a bathtub

would attract a bit of attention on the high seas,

but I guess everyone was just going about their buying and selling.

so they didn't notice someone so small.

If they had known what I was doing,

i'm sure they would have stopped me.

That's part of being a superpower. THE superpower:

you have to annihilate anyone in opposition to you.

Even if they're in a bathtub

but they have to notice you first.

When roger and I first divorced, I'd stay in the bath all day.

I'd lay with my head submerged, and my

friend louise would come in and scream,

"Don't do it!!! Don't do it! He isn't worth it!"

but I was just relaxing. I liked to hear my own heartbeat.

Which you can do in the bath. Ears under water,

it comforted me.

Louise made me go to her therapist, Dr. Shapiro, who came up with some stupid theories:

"You're trying to rebirth yourself. You're trying to go back into the womb and start again."

"Honey." I was like, "Honey, believe me, if I had to do this again I would definitely not come back as Lola Palatska. Trust me. And I sure as hell wouldn't be doing it in a bathtub."

But look at me now.

If he thought I was trying to rebirth myself in a bathtub in Brooklyn,

he'd have a field day with the Pacific Ocean.

I do things big. I can't help myself. 
I'm Polish. Polish people always do things big. It comes from too much starch in the diet.

$*$

I've brought two books: one is Cassandra, and the other

is my book of brain teasers.

every morning, come rain or shine,

I do a brainteaser. Not that there's been any rain but

I've only got one left after this.

(smiles)

I might start back at the beginning, I'd probably have forgotten the answers

by then. Mercifully, I have a very short memory.

Let's see: what's today's going to be?

(she opens her book)

"Crossing the river". Okay.

"Jake was standing on one side of the river, and his dog Scruffy was standing on the other. :come on Scruffy, come, boy!" shouted Jake. Scruffy crossed the river, ran to Jake, and got a treat for being a god dog. The amazing thing was that Scruffy didn't even get wet! How did Scruffy do that?"

Hmm. It was obviously not the Pacific that Scruffy ran across.

Okay. Let's think about this rationally.

I'm terrible at thinking rationally.

Which you may have already figured out.

Obviously Scruffy, unlike me, could swim.

(puts the book down)

I'll come back to it later.

*

when I was in seventh grade my class did a unit on greek mythology.

my favourite was artemis the hunter.

I remember exactly what she looked like, in her little

chain mail outfit.

I always hated the ones I was supposed to like, and

liked the dangerous types. dionysis for example. I loved him.

selfish, sure. up himself, fly by night, no real talents, I knew all that.

but he was beautiful, romantic, and free. he had nice hair.

that is, until his mother ripped his head off. but I still liked him.

then there was that whole fiasco at troy. I was supposed to love the beautiful helen, and feel sorry for her that she got brought to this foreign city.

but no. I thought she was insipid.

a real whinger.

I liked cassandra, the girl with visions.

I liked the fact that no one listened to her.

but mostly, I liked her for going on her journey, even though she knew it would end in tears.

that's why, when it came to standing on the pier

the city coming down around me 
flames out over the water

(i'm just making that up. really it was another

grinding summer day in the financial district

and the wheels of capitalism

were busy squashing everyone in their path,

successfully as ever)....

but when I stood on the pier and found myself falling

when I hit the the bathtub

bobbing next to the QE II

I had a moment.

just a moment.

and I thought it might be worth keeping the

cassandra with me after all.

just to steady my heart.

just to remind me that

no matter what happens when you get there

it's the going that's important.

The letting go.

Even if it ends in tears.

I have this idea:

That I'll set out, sail away, and finally...maybe...arrive.

(That'd be a first.)

And that when I arrive in a new place, I'll get out of the bathtub,

kiss the ground,

stand upright, and see myself standing on the shore

facing me.

Because like my dad used to say, 'the trouble with leaving is no matter where you go, there you are.'

*

(she goes back to the brainteaser)

I'm never gonna get this one. I'll just have a peak at the answer:

"There are 2 possible answers. 1: The river was frozen. \#2: There was a bridge over the river, and Scruffy crossed the bridge." Bullshit.

They didn't mention the third possibility:

Scruffy drowned.

And Jake was so in denial, he imagined Scruffy made it across

To save himself the anguish.

I'm freezing (even though)

It must be a hundred degrees.

Baking.

But I shake. Funny. So cold.

(rest)

Mrs. Baldwin, my tenth grade History teacher,

Is wiping my face with a damp cloth and pouring sweet tea down my throat. 
She wears White Linen perfume from Estee Lauder and her fingernails are painted mauve. I didn't know what mauve meant until I was seventeen, but I loved her nails. Mrs. Baldwin is both sexy and sensible, and always knows what to do in a sticky situation.

She's telling me about various Pacific Islands, about the Contiki about Captain Cook.

She's been telling me about all these little islands I've been passing... And what it was like when she was 15, back in the day, Before there were bathtubs.

Well. Practically.

I'm scared, Mrs. Baldwin.

God knows what can happen to me out here. I'm a sitting duck.

Mrs. Baldwin strokes my face and her hand is warm.

There's a trail of heat from her fingers across my skin.

I'm glad I can feel something.

*

It gets lonely when all you've got for company

Is your own dangerous mind.

so I invent people, shipmates, fellow-travellers.

They're perfect companions:

don't talk much

don't take up much of the tub.

I make them up as I need them,

then banish them when I don't.

I've walked a few of them off the plank.

I cast away a few too.

I hope they made it to shore. to some shore.

I love them and leave them.

I'm fickle, moody, totally self-absorbed.

Like Dionysis. God, he had nice hair.

*

That morning, that last morning with Roger,

He was getting ready for work, brushing his hair in front of the

Mirror in the dining room.

Like, really brushing it! You know? It was weird.

Roger, what are you doing? You look like you're about to have a big orgasm.

He looked at me.

Then he looked at himself. for a long time.

I'd fuck me, he said. and I knew in that instant I had to leave him.

But after he left?

After he slimed out the door in his million dollar suit looking

Really, he looked great, there's no two ways about it,

He did. But who wouldn't in a million dollar suit?

After he left, I went to the mirror, picked up his brush, and 
Stared at myself. I smiled.

I'd fuck---I'd---

I couldn't do it.

I hate Roger.

I shouldn't be surprised it's come to this. Or not come..to this... as the

Case may be.

My mother never taught me anything.

I'm not familiar with the topic, she said.

Didn't want to misinform me.

Of course there were Mrs. Baldwin's fingernails.

They hinted at something more.

And the way she floated around the lake with a wine glass in her hand.

It was obvious she knew a lot.

What's it like?

I finally asked her one day, floating ten feet away in my own

Inner tube, staring at my fat thighs.

What's what like? She laughed her Tinkerbell laugh,

Knowing exactly what I meant.

Sex.

She giggled and flicked the water with one mauve fingernail.

It's better than chocolate.

I considered that for a while.

Is it better than music?

She thought about it.

Probably not, but it depends on who you're with.

She didn't mind laughing about sex.

She laughed about condoms and rude positions and adultery.

There was nothing about sex that wasn't hilarious to Mrs. Baldwin.

You'd think it was a goddamned Marx Brothers routine the way she laughed.

It was really annoying.

When Mr. Baldwin came out on the dock to refresh our drinks,

I knew it had nothing to do with him. Her laughter. Her happiness.

And then I knew I could tell her anything and she probably wouldn't

have me arrested or tell my parents.

I've slept with Jim. I said.

Oh, I know!

She laughed like a hyena.

Then I started laughing, which annoyed me even more.

I stopped laughing.

What do you mean you know?

I can just tell.

That was enough to terrify me.

Do you think my mother knows then?

No! she says. You have to have sex to recognize it on other people.

My mother might have sex. 
Trust me, she doesn't.

It took ten years, but my mother finally confirmed the horrible truth, and it was then I decided if there was a god in heaven I wouldn't turn out like my mother.

But I have.

I fucking have!

When did it happen? Who knows.

It could have been that Wednesday in March when I

Finally wore track suit bottoms to the supermarket.

I knew that was a mistake.

Roger said he didn't want to have sex anymore.

By then we weren't having sex anyway, so it seemed like a

Statement of fact, not a declaration of independence.

I went along with it because...I was busy.

I was...trying to do the right thing.

My fingers went numb first.

Then my legs.

Then my mind.

My heart was the last to go.

Who knew that sex was connected to so many bits of yourself?

We need to spend time together, Roger, I said. I was my mother.

I still couldn't say fuck.

We spend loads of time together. We're connected at the hip.

Yes, but that's not where I want to be connected at.

He laughed.

He laughed a Mrs. Baldwin laugh and went out for the evening.

And then I knew.

It was the girl in the dolphin costume.

Well, not exactly, but what's the difference?

She was sleek, wet, shiny skin.

By then I was numb anyway.

I don't know why I bother thinking about this shit.

$*$

What bugs me about it is, I guess....

It's just--

Where did I go?

I went back to being 15 .

I went back to dreaming about sex, merging with someone,

Being stroked and seduced and undressed and fed strawberries.

I started to live more and more in my mind.

Arching backs. Tender lips.

Sweat.

I dreamt hot dreams. I was the only one who knew what I wanted.

I ran my hand along my thighs, my belly,

I laid in bed and I cried 
While roger played racquetball.

He's very fit, Roger.

Looks great for his age.

I started watching Roman Polanski films.

Which is never a good sign. I did try:

Roger, my body is dying.

Are you sick? It's just a cold.

Roger, my body is shutting down to me. I can't feel anything. I'm cold.

Put a scarf on. You don't look after yourself very well, do you?

By the time I started going to McDonalds for breakfast,

I knew I was in trouble.

But by then it was too late.

I wore big clothes with long sleeves so I didn't have to

see any part of myself that looked beautiful, tender, hungry.

I started smoking.

But sometimes, just once or twice maybe,

In the middle of the night,

Laying there awake,

I'd get up

Take off my flannelette pajamas

And dance around the living room.

Dance.

Dance for my life.

\section{END OF SECTION 1}




\section{SECTION 2 - high noon. Scorching.}

It's the blue that scares me.

Sometimes I just wish I could...

(she experiments with tipping her toes out into the water)

Not swim, just walk, skate around. taste it.

I wish I could eat the blue.

(she bails the boat, plays in the water)

This boat is leaking. I'll probably end up in the water soon enough.

*

Why wasn't I frightened?

even when I was sure that

this leaving would be the end of me.

of the me that was in brooklyn with roger

and lentil soup simmering and the fresh market on Sundays

and the new york philharmonic on the great lawn in Prospect Park -

I knew this one would die then.

and I walked away. happily. eagerly.

with no more worries than when I was leaving

my dirty washing at the laundromat.

it wasn't until just now that I realized

how much I love the person that I was,

how much grief, how much terror

makes a person fall away like that.

my dreaming mind tricked me.

because you know, it withholds.

until it's too late to change your course.

your own course of history.

*

ever since I left the pier, my dreams are all about opening.

I have dreams about being wide open. I want to be so wide open I take in the whole world.

I take in tongues and fingers and dicks and oceans and fishes and blenders and holdens and subcontinents.

I'm serious.

my sex life is a phantom limb. it keeps aching, even though I know it's gone.

I am trapped in my skin,

trapped in my bones,

trapped in this leaking tub.

frozen.

sailing through life a thousand miles away from others.

but

when the wind blows,

out here,

when the wind strokes me, 
moves my hair,

ruffles my clothes,

I realize how badly I crave to be touched.

I'm in a retirement home in my heart.

I'm isolated and aching.

I wait for the carers to come in at 8 am and hope they will

Touch me, move me, bathe me, dress me.

I pretend I'm paralyzed just to get them to touch my skin.

*

The first time I summoned him was about a week after the divorce.

Oh sure, I'd seen him around.

But that was the first time I'd invited him in.

I think it was the moustache.

I like a guy with a moustache.

I don't know why: Roger never had a moustache, and my mother couldn't stand men with facial hair.

She said it made them look shifty, but I suspect it was really more about hygiene.

I liked the way he smiled.

He looked like a little boy.

Like he had a secret.

I used to talk to him, play with him in my mind.

Nothing very....intimate, not then.

But out here.

Well.

The sky's the limit.

He's got a dubious past. Doesn't like to talk about it.

That's the old me. He says. That one died. He doesn't exist anymore.

He's irrelevant.

But you know.

Girls like to talk.

And you can't just sit in the tub all day.

Tell me a story, I begged him.

That was in the early days, soon after I lost sight of North America.

I went to New York to start over, was all he'd say.

But I wanted more.

That's always been my trouble.

I couldn't breathe. When I first got to New York, it took me three years to

Remember how to breathe.

Three years? I say. What were you thinking?

And he says, (I love this, it makes me laugh every time), he'd say

I wasn't.

But three years...

Life's long, he says. I'm a slow learner. 
But he's different from me. He wants to breathe. Do you know how to breathe? He asks me. Do you know how to breathe under water? I don't answer. I don't know what to say. But I sink into his words like a...well, yeah, Like a warm bath.

*

My father doesn’t like my Mystery Man.

Of course.

I don't trust him, he says.

Don't trust him as far as I can throw him.

But out here, distance is relative.

And you doesn't trust anyone, do you?

The tub's getting a little crowded.

The problem is, I can't choose.

I mean, I can't walk my own father off the plank, can I?

And I'm not ready to part with Mystery Man just yet.

Sure, sometimes he goes too far. But he's mine.

*

So who am I?

Ok, I was born to certain parents, with certain siblings, in a particular place and time, and so for all intents and purposes these are my people. this is the landscape of my heart.

I may leave them

I may hate their guts.

But my earliest childhood memories are impregnated here. in my mind. in my heart. in my blood. irrevocable.

My people become the only ones who Know The Whole Story of Me.

And in some weird way, this...fact...becomes more important as life ebbs away.

You knew that much, at least.

*

What? You know what I'm talking about. * It's like this:

*

You went from West Texas to Death Valley.

You thought they were the same, because they looked the same.

You was fooled.

You thought you were getting a new life.

Instead, you lived with ghosts from the age of thirty instead of

from the age of seventy.

You had a wide circle of friends - in your mind.

You travelled widely - in your dreams.

There was no difference between your dead and your living everyone who was important to you was gone.

If not literally, then geographically. 
And rather than help to go home on visits, it was like a great tear, a great gaping tract of scar tissue up your guts, across your belly, through your heart and every time you saw or spoke or held or listened to someone from home, this great wound split open and threatened to destroy you.

So you began to leave it further and further behind.

And the truth was that even before you had left West Texas

your heart was already on this path, because you had never known your people, being an orphan.

You had never known the heartbeat that you listened to in the womb had never heard the laugh of your first days had never gazed into a face like your own and so even before you chose exile, you had been exiled.

the geographical move just confirmed and externalised what you had felt for so long inside.

You were a stranger in your own land. And then a stranger in a strange land.

finally you lived so much in your head that you would look around at the rest of us: your wife, your children, your neighbors and friends, with a look of utter incomprehension.

and although it looked to us like contempt I realize now that it was fear. you didn't know how you'd arrived in this place. you didn't know where you were, nor who we were. nothing looked familiar.

Now I have the same view on sleepless nights. when the ocean's calm.

We come into a strange land alone, in a mystical and mysterious manner. We don't know how we arrive, nor when and how we'll depart. We grow accustomed to some things and some faces, But by and by they leave or change or die, And we're reminded that we're just visitors here. And our stay is short and tenuous.

$*$

it's been a long time now since any fish came by.

at first, it was constant - every day,

fish jumping, singing out, ushering me along.

now, for the past four days, only silence.

I'll call him.

Mystery Man! Oh Mystery Man!

just for company.

but he's a tease. 
When he senses - and he's got excellent senses -

When he senses that I need him most,

He stays away.

Sulks.

Silent treatment.

It drives me crazy.

He likes to hear me calling for him.

Mystery Man!

(nothing)

I'm gonna pull the plug.

Oh! That got your attention!

Mm.

You know what?

Even you're getting on my last nerve.

Get lost.

I don't care what you heard, I didn't say it.

(beat)

Well if you heard it, why ask me what I said?

Hmm? Ha! Gotcha there.

(rest)

I want someone to touch me like that again,

I said.

That's what I said, okay? Happy? Fine.

This is the way we carry on, day after day. so this morning I walked him out the plank.

But now he's back, begging like the dog he is.

a girl could lose her...(virginity). mind.

Get out.

what do you mean, no? I said get out.

this is my tub.

go on now go.

Don't turn around now,

you're not welcome anymore.

(beat)

Dad, this is none of your business, okay?

I'm forty-three years old and I can see who I want.

$*$

I don't have to put up with your

(choking)

get your hands off me 
(gets away, frightened)

you're nothing. you're a figment of my--

(flips out of the boat)

Oh, my legs.

I can't swim. I can't swim!

Let go (of me)----

(in the water, hanging onto outside of boat)

Pull me up, you cunt.

Pull me up.

(he is smashing her fingers, one by one, and she is letting go.)

I--stop--that--

(she is trying to swim)

(she starts to drown. Somehow she emerges. Half-into the boat. Collapses.)

[REST]

(whoosh! a big faceful of water)

Whoa!

in slow motion, a black shape rises out of the water.

slowly, smoothely, thick and black and dripping.

"Take cover!" screams Dad. "Killer whale!"

keep still, I tell him. Go to sleep.

As usual, he does.

(watching)

I can hear the whale's heart beating.

He could capsize me, so easily,

like a leaf in a creek,

like....he wouldn't even feel it.

five feet to the right, and I'd be

shark food.

but here we are.

staring, waiting, breathing.

(she does)

as the biggest eye, the biggest softest eye

ever created, ever opened or blinking,

not even an eye, but a window on the whole world

on the past, present and future

surfaces out of this bed of water, this

calm black fathomless water,

and looks me straight in the face.

(she goes to meet him) 
OK. Come on.

(challenge)

You got something to say to me?

(they square off)

it hangs there motionless.

We breathe together.

(smiles)

"IT's JONAH!!!" Dad screams.

I never knew he was such a scaredy-cat.

It's not Jonah, I whisper, but I don't look away.

Jonah was the guy, not the whale.

This is the whale.

Dad goes back to sleep.

Maybe it's the same whale.

Maybe the whale is remembering.

Maybe he's sizing up the bathtub for indigestion.

He must have made up his mind because

(he takes a swipe at her)

Aghhhh!

He's out of the water, his mouth is huge, wide open.

The earth.

The milky way.

The cosmos.

Me.

I want to be inside him.

Now.

No fear.

*

(they prepare to battle.)

Don't just hang there, over me,

with your hot breath

and your hot hunger!

I'm not cold anymore.

Let's go!

(they battle)

(samurai) I surrender!

(in the belly of the whale)

I'm gone.

END OF SECTION 2 


\section{SECTION 3 - dawn}

(she wakes up in a bathtub in the middle of the ocean)

Where am I?

What am I doing in a bathtub in the middle of the ocean?

There's a joke there somewhere.

A bad joke.

About a girl who has to open her eyes again. Oh god.

Help!

Hey! Anybody!....

*

okay.

(she sits)

breathe.

Why don't I ever have my mobile when I really need it?

(sunflash)

*

white.

Blinding white.

It felt like I was falling for years.

When I left the pier, there was a short rush of air

And then...nothing.

Until I hit the water.

It wasn't until I hit the water that I remembered.

Five years old and standing in Crystal Lake with twenty other

Five year olds.

Cutting the water like skin.

Practice swimming, it was, just to get used to the motion.

Pretty daggy.

But when it came time to go under....

When I had to stick my face below the surface,

And my body wanted to sink

My brain wanted to run

And my arms wouldn't work.

Legs, sure. Kicked and kicked, I was always good at kicking.

But the rest of it just went downhill from there...

I never learned to swim.

To my mother and Mrs. Johnson's dismay.

It never bothered me.

I figured there was enough to occupy me here.

*

(she is drowning)

When my head went under the water this time,

The oil slicked water off pier 14,

Heartbeat in my ears. 
I was sinking fast in water so blue it surprised me.

How polluted does a river have to become before it stops being blue?

I was drowning.

Everything came rushing in, all I had been trying to avoid:

Water. Voices. Silence.

And then, as suddenly as everything went quiet,

It exploded.

Loud, like fireworks, and white.

Enamel.

*

Last night the moon came out.

Stars.

I lay here,

Like a baby.

And just looked, just took it all in.

Like I'd never seen the sky before.

I lay in my tub

And I thought about Dad

And Mrs. Baldwin, and Roger,

And Mystery Man,

And all the others.

All the others.

All the millions of others I've been filling up my life with.

(rest)

it was a clear night, you know?

Crystal clear.

Not a single breeze,

Not a bird, no voices, nothing.

For the first time,

Silence.

Couldn't hear my heartbeat.

Didn't feel afraid.

Didn't feel cold.

I thought for a minute I'd died.

I thought I'd finally done it.

After all that trying, I thought

Well, you've finally done it now, just when you figured out you wanted to live.

But you know.

Timing is everything.

Look at the sky.

Did you ever notice a kind of...skin around the moon?

There were these lovers once... in a movie.

And the boy was telling the girl the difference between a liar's moon

And a lover's moon.

One of them has this kind of skin, this haze around it.

That's what the moon has. 
A big white full moon with a skin.

(But) I can't remember if it's a lover's moon or a liar's moon.

*

Hey diddle diddle, the cat and the fiddle, the cow jumped over the moon.

The little dog laughed to see such sport,

And the dish ran away with the spoon.

*

I laid there and watched that moon for a long time.

I didn't think about the brain teasers

Or Cassandra, or anything.

the me was gone.

The noise.

I liked it.

I felt the moon rays on my body, on my skin,

I drank in the moonlight, like it was water.

I bathed in it.

I rubbed and scrubbed my skin, and turned and rinsed in it. I breathed it into my lungs, and stretched out my spine in it.

(she bails water out of the tub)

The owl and the pussycat went to sea

In a beautiful pea-green boat:

They took some honey and plenty of money

Wrapped up in a five-pound note...

I reckon I'm losing this bailing game.

There must be some cracks where I can't see

Because it keeps filling up with water.

Last night, with the moon and all that

I decided I'd pull the plug.

Just to see. You know. What happens.

Water outside, water inside, what's the difference?

So. Today's the day.

It's funny, a person can get used to anything.

You start to think that's the way it's always gonna be. Drifting.

And then one day you just wake up and you know.

(rest. Breathe.)

Today's the day I pull the plug.

*

(without emotion)

I was five years old when I sat at the dining room window

and decided I would never surrender again.

My parents had gone out to dinner. 
Suzie the babysitter was watching a movie in the living room.

She'd put me to bed, but I snuck out.

I sat at the window, staring into the full moonlit night,

Down the driveway to the road, searching for the headlights.

I waited and waited and waited.

(whisper) Don't move a muscle!

I can still feel the anxiety in my belly like a hard rock, like a stone

Like a piece of granite clenched in my teeth, grinding,

I can feel the stone turning in my belly, sucking up the warmth.

I can feel the stone sucking up the warmth of my blood and replacing it with mercury.

I can feel the mercury pulsing around my veins, my limbs with the fear of death and abandonment.

Cold.

I am staring out the dining room window down the long long

Driveway of my shit-scared childhood hoping and beseeching whatever god there is not to let me be left alone again.

I can see the blue blackness of the snow.

I can see the moon on the silver waves of snow. I can see the fear

Between me and the blackness and the silver waves, and the headlights never come.

There is no light. No end. Only the tunnel. Only my clamped shut tight jaw vowing vowing never to open again.

Not to scream, not to swallow, not to eat, not to cry, not to moan.

I've always kept my promises.

There are shadows and fear and the stone in my stomach and the headlights never come.

I cry and cry and cry and mostly even more than this I feel my fingers

Tightly gripped

Like little claws, gripped on the windowsill

On the three-tiered windowsill of the diningroom window of my childhood all of which is now gone

And the cold

Waiting for the headlights that never come.

There's a man, walking slowly, his outline, toward me.

But then the moon comes out from behind a cloud and he disappears.

Was never there.

Suzie puts me back to bed, and sometime later, out of childsleep

My bedroom door opens, the crack of light grows and fills with my father's face

And he is home.

I'm grown up now I guess. A woman.

I'm an adult, running my own life, taking care of myself

Or not.

Because adults get to choose.

Because I'm an adult and that's what adults do and yet. 
Every act of the adult carries within it the act of the child.

(aha! The answer...)

Brainteaser!

(she pulls the plug. Nothing happens. Rest.)

That's weird.

The water's not coming in.

(she looks closer at the drain hole)

What the hell!

I wish I'd paid more attention in science. There must be some law of physics or something about water on the outside versus water on the inside.

Or maybe it's that old saying about the tub being half empty.

Half full.

Hmm. Very strange.

I don't understand.

I thought once I----

(she hits land)

Shit!

This was unexpected.

How could I have missed it?

(she looks around. Not sure if it's a mirage.)

Hmm.

(touches the sand outside)

Looks like land.

Feels like land.

Smells like land.

Must be land.

Hmm.

(she doesn't move right away)

I wonder what I'm supposed to do.

Where am I?

(she stands. Stretches. Stiff.)

Oh, ow. I need to get out more.

(tentatively puts out a foot, tests the land)

Seems okay.

(other foot)

Nice.

(rubs her sore butt, physicalises)

That feels good.

(does a few stretches, looks back to sea, fondly)

Funny. 
(it starts to rain a tropical rain.)

Mmm, rain. Finally.

(she bends, kneels down into the ground and sniffs.)

I want to taste it.

(She kisses the ground. She takes some sand in her hand and puts it to her lips, into her mouth. Swallows.)

I'm gonna keep some of this new land.

For my kids.

I'm going to make them eat the dirt when they're born, gonna shove a thimbleful of sand in their little mouths, make them swallow

and that way they'll never leave.

they won't need to.

(she kneels, wraps some sand, somehow)

It'll be in their blood.

They'll belong.

(she stands, walks inland)

*

I wonder what will happen to my whale.

To Cassandra.

To me.

I wonder why we tell stories,

Why we listen to them.

To movies, books, brainteasers, myths.

When we can't even listen to ourselves.

To ourselves.

(she notices someone)

Hello.

Fancy meeting you here.

And hand in hand, on the edge of the sand

They danced by the light of the moon,

The moon,

(The moon),

They danced by the light of the moon.

(END OF PLAY) 


\section{Research statement}

\section{Research background}

This work uses solo performance text to explore themes of sexuality, gender, aging and migration. The work shares a new kind of reflective knowledge creation with its audience. The play models a new way in which research may draw upon the past, the imagined future and a cast of not only 'real' characters, but imagined (and nonhuman) ones as well - as does research in emerging areas of sensory research methods, social fictions, autoethnography, performance ethnography, spoken word research, personal narrative and feminist research performance. This script is one example of this new kind of knowledge creation in which the characters become research subjects and research outputs. As Boal (2000) argues of lived experience (as agentic and reflexive), this performative ethnography (Spry 2011) continues to evolve in and as ethnographic research through additional interviews, micro-performances and evolution of the script.

\section{Research contribution}

This play represents the ways in which literature, interculturality, migration, gender and sexuality can be present in research in evocative ways. This play shows how 'the fiction is embedded in the ... interviews, collegial conversations, and creative collaborations ... experienced in ... arts-based research' (Harris \& Sinclair 2014: 2). The work represents the multiple experiences and perspectives present in this research informed by gender and sexuality, migration and multicultural education, in innovative ways which are characteristic of contemporary new materialist and sensory research.

\section{Research significance}

Lola's journey-as-research contributes to these fields in extending the limits of performance writing and how fictional characters might not only represent but 'talk back' to creative researchers and audiences. She as a character and as an ethnographic amalgam of research data represents what Leavy's core text Method Meets Art (2008), and others (Cahnmann-Taylor and Seigesmund 2008, Barone and Eisner 2012) have mapped as the potential of practice-led and arts-based research.

\section{Works cited}

Boal, A 2000 Theatre of the Oppressed (new ed) Pluto P, London

Barone, T \& Eisner, E 2012 Arts based research Sage: Thousand Oaks

Cahnmann-Taylor, M \& R Seigesmund 2008 Arts-based research in education: foundations for practice Routledge, New York

Harris, A \& Sinclair, C 2014 Critical plays: embodied research for social change Sense, Rotterdam Harris, A 2012 Ethnocinema: intercultural arts education Springer, The Netherlands 
Harris, A 2011 'Slowly by slowly: Ethnocinema, media and the young women of the Sudanese diaspora’ Visual Anthropology 24 (4), 329-44

Leavy, P 2008 Method meets art: arts-based research practice Guilford, New York

Spry, A 2011 Body, paper, stage: writing and performing autoethnography Left Coast $\mathrm{P}$, Walnut Creek 


\title{
Griffith University, Australia
}

\author{
Linda Hassall
}

\section{Motel chronicles}

\begin{abstract}
:
Motel chronicles is an investigation into Hassall's preoccupation with a land/culturescape (Chaudhuri 2002) experiences. Set within the sceneographic framework of a motel, the play makes a claim for the value of atmospheric landscape as central to behaviours investigated within the fiction. The chorus of characters convey the stories secreted within the motel walls. Experimenting with form and style, the work is a heightened theatrical expressive experience. Motel chronicles harbours the detritus of society into a momentary refuge, hiding those who wish to be hidden. Inspired by the early dramatic works of Sam Shepard and the poetry of artists such as Penny Arcade, Fritz Hamilton, David Learner and Lisa Martinovic, who are identified as outlaw, renegade poets in The outlaw bible of American poetry (1999), Motel chronicles is a rock and roll psalm of faith and forgiveness.
\end{abstract}

\section{Biographical note:}

Dr Linda Hassall is a lecturer at Griffith University in Contemporary and Applied Theatre. Linda has over $20 \mathrm{yrs}$ experience as a director, playwright and dramaturge in professional and independent contexts. Linda's first published play Post Office Rose won a Matilda Award for Best New Play (2006). Linda's published play A Contemporary Hymn (2012) in I Will Kiss You in Four Places, examines the effect of urban landscape on youth culture behaviours. Salvation a performance piece derived from her $2012 \mathrm{PhD}$ research was published by TEXT in 2013. Linda recently directed Debris (2004) by Dennis Kelly at Metro Arts, Brisbane as part of her research into urban landscape and its effects on socio cultural behaviours. Motel Chronicles extends this field of artistic research while investigating forms and styles of performative communication and expression. Her latest commissioned work; The Return - the final phase of The difficult return (three year ARC funded project) was produced in June of 2014. The return explores the impact of combat experiences on returning veterans and their families.

Keywords:

Creative Writing - Urban landscape - Post-dramatic writing - Australian Gothic 


\section{Motel chronicles}

\section{Characters}

PROPRIETOR - Owner/Operator of the Motel.

CHORUS - There is a female chorus of prostitutes who operate out of the Motel. The female chorus members may also take on the characters of female guests.

GUESTS - Generic male and female guests who spend short periods of time in the Motel.

\section{Setting}

The setting as described evokes a heightened atmospheric aesthetic depicting a Motel on the edge of time. It is somewhere over there in the distance behind the neon haze of an urban night landscape. It suggests an environment that harbours the detritus of society...those individuals' that desire anonymity. Rather than rooms the shifting scenography of the Motel is organic and created by utilising cardboard suitcases in numerous theatrical ways.

\section{Note}

This text is inspired by the works of Sam Shepard especially his autobiographical work, Motel Chronicles and Hawk Moon (1982). It also pays tribute to the anthology of American poetry collected in The Outlaw Bible of American Poetry (1999). 


\section{Scene 1: Vacancy}

Proprietor: Signs on. Vacancy. Welcome. Come one. Come all. Stay with me on the corner of this side-show street! Get of the round-a bout for a while and let the circus pass you by. Be warned though. Catholics cross themselves on entering. Yes they do.

Prossie 1: You can bleed/

Prossie 2: You can breed/

Prossie 3: You can put a bag over your head and turn blue in the face. We take all major credit cards.

Guest: $\quad$ There's a stink of stale urine with a dash of formaldehyde.

Proprietor: There's room for you, yes you with your pride bashed all black and blue. Double or single. Flat rate.

Prossie 4: We got deterioration/

Prossie 5: Decomposition/

Prossie 6: Blanketed in a fine layer of filth.

Proprietor: Unpack your pain and your shame and your lapsing faith. Just \$25 a night.

Prossie 1: We'll provide you with a caricature of intimacy.

(soundscape of a collection of motel sounds: blue movies, sex, taps dripping, people crying. Soundscape can also identify the urban landscape: nightclub music, sirens, traffic, drunken fights).

Proprietor: Yes we will! So come talk to your god or your gun or your dead little girl. A room with a view's just waiting! Alright, there's no view but there is a room...waiting for you.

Prossie 2: $\quad$ We got pillows to cry on and televisions to kick.

Proprietor: 24 hours for $\$ 25$. Vacancy. Come dream your dreams. Cash or credit $\$ 25$ a night.

Prossie 3: There's relief/

Prossie 4: Reprieve/

Prossie 5: Retribution/

Prossie 6: Redemption/ 
Chorus: $\quad$ Vacancy...vacancy...

(the vacancy neon sign is a beacon in the darkness that descends as the soundscape of the night escalates).

\section{Scene 2: The Guests}

(the sign, now reading no vacancy flares. Several of the chorus members are sitting in separate suitcases littered across the space. Each suitcase represents a separate room. Off, a gunshot is heard).

Guest 1: I'm going to leave my conscience pressed between the pages of this bible in the drawer.

Guest 2: $\quad$ Today I am fragile. Pale. Twitching. untamed and full of purpose.

praise Jesus and pass the ammunition.

Guest 3: $\quad$ He didn't die for my sins. Jesus, i wasn't even born then.

Guest 4: $\quad$ Today I try and concentrate on small things. bougainvillea threaded through chicken wire.

half drowned kittens mewling in cardboard boxes.

Guest 5: $\quad$ I saw god cry once.

I saw him cry in the reflection in my enemy's eyes.

Guest 6: $\quad$ And as his enemy she said, love me. Please.

Guest 7: I whisper to god. I whisper about those bastards who can't see the beauty running under the pale crusts on my skin.

Guest 8: $\quad$ If try calling him...god...i keep trying... every night. I call to him.

Guest 9: $\quad$ I ask god about the infrequency of cleansing rain.

(it rains midnight rain). 


\section{Scene 3: Are You Lonesome Tonight}

Proprietor: In one of these rooms some lucky bastard is talking with Elvis.

'Are you lonesome tonight, do you miss me tonight?

are you sorry we drifted apart?'(Presley, 1969)

Talking with the king. Discussing sweethearts. Or god or lost little girls.

When you check in with Elvis you're faith tags along. Your faith is sitting right there with you under that buzzing fluorescent bathroom bulb. Faith's holding the blade or the bullet. With a smile on her kewpie doll face. 'tell me dear, are you lonesome tonight...' (Presley, 1969).

\section{Scene 4: Some Trouble}

(soft humid rain falls. There are two yellowed street lamps. These lights spill across two prostitutes trying to drum up a little after midnight business).

Prossie 1: I wanted to go home once. But I couldn't seem to find the house. The house i lived in. Once. The house I lived in once. In another life. It was like it disappeared. It was quite a big house. I lost it though. When we were kids my sister would rub her Barbie's face in the mud under the dripping tank stand.

Prossie 2: $\quad$ People are selling radio-active phones to kids these days/

Prossie 1: The house that I lost had peeling paint. It was cool. Probably 'cause every couple of months my old man'd smash all the windows. After he'd finish smashing my mum.

Prossie 2: /and healthy cereals that make us obese. Five teaspoons of sugar per serve. Five teaspoons of a-d-d and childhood obesity/

Prossie 1: My mother moved through that cool house in a dirty flannelette nightdress dropping her cigarette butts on the floors. Leaving smoulder marks on the lino.

Prossie 2: We've got politicians who think scrapping a carbon tax is a good career move/

Prossie 1: The day I decided i couldn't take my old man comin' into my room anymore, in that big cool house with the broken windows and the tank stand - I left. I packed my mum's nightdress and just walked down the road.

Prossie 2: We've got anorexic girl-women with eyes like wet concrete peering at us from the pages of magazines and fat celebrity chefs telling us to cook with butter/

Prossie 1: $\quad$ As I walked, my house started to fade. It shimmered out of my life. I walked until i reached a road...then another... i took a left...then another. And it was gone. 
Prossie 2: Kohl tinted baby eyes that promise to fuck you 'till you come blood and reality $\mathrm{TV}$ that promises you can eat all sorts of shit and still be the next biggest loser if big brothers not watching.

Prossie 1: Did I tell you I'm having trouble finding my way back to that house. I lost it somewhere along the line. Along the road.

Prossie 2: We should all just add little weed killer to the chocolate sauced chicken, a little rat sack to the paella.

Prossie 1: It's hard to go forward when all you can call your own is a dirty flannelette nightdress.

Prossie 2: If you can't make a reasonable pork belly risotto, poison the cereal. I got some. It's easy enough to get.

Prossie 1: $\quad$ And it just faded away - that house.

Prossie 2: $\quad$ Do you want some? Do you?

Prossie 1: I reckon my mother would have cried when i left. When she realised I'd taken her only nightdress.

Prossie 2: $\quad$ you'll make the news. C'mon just one bite.

(a guest approaches and sizes up both women and moves to prostitute 1.

Prostitute 2 steps into the road. A truck horn blasts. An ambulance siren is heard off.

Rain continues).

\section{Scene 5: Early Morning Minutes}

Proprietor: Faith has gone out. She's been called away in the early hours and Elvis lovers will wait in vain for her return. Heart beats tick off the minutes in time with the digitised clock radio. Faith left her belongings on bathroom sink. Just in case.

(the vacancy sign flashes quickly to no vacancy then back again. Rain is heavier. Five separate areas. Five separate rooms. Each guest has a particular action they are caught in the moment of. Soundscape: prostitutes having sex. Breathing. Hearts beating. Clock ticking. A woman screams somewhere in the distance. Someone cries softly. Nightclub music).

Proprietor: How long is a minute?

Guest 1: $\quad 3.30 \mathrm{am} /$

Guest 2: $\quad$ Is that a rooster? Is it? Or some woman screaming out there in the distance?

Guest 3: $\quad$ The sky is black. It empties me of dreams. 
Guest 4: $\quad$ Is this a motel room or someone else's house?

Guest 5: $\quad$ Where the bloody hell am i!!

What the hell is this place called anyway!!

Guest 1: $\quad 3.32 \mathrm{am} /$

Guest 2: $\quad$ What time is it?

Guest 3: $\quad$ My thoughts are no longer friendly.

Guest 4: $\quad$ I pray for a break from thinking.

Guest 5: $\quad$ A clean break in a blank space.

Guest 1: $\quad 3.33 \mathrm{am} /$

Guest 2: $\quad$ Please let me hit the road empty headed.

Guest 3: $\quad$ Just once/

Guest 4: I'm not begging/

Guest 5: I'm not getting down on my knees...but just once...please?

Guest 1: $\quad 3.33$ am.

I'm in no condition to fight.

Proprietor: How long is a minute? It depends on what side of the motel door you're on... (someone in another room turns on a radio and Elvis takes up the conversation about being lonesome tonight).

Proprietor: Is that faith I can hear? Knocking on your door?

(it continues to rain).

\section{Scene 6: I Wanna Be a Cowboy}

(a guest is unpacking items from a suitcase. He pulls out a sheriff's badge and attaches it to his shirt-left breast pocket. The last thing he unpacks from the suitcase is a prostitute.

Throughout she unsuccessfully attempts to get him aroused. Soundscape is the static of a tv. Every now and again there are snatches of old Westerns).

Guest: $\quad$ Anyone give a cowboy any shit. Bang. See ya later partner.

(the proprietor watches him). 
Proprietor: Tombstone. Gunfight at the o.k. coral. Wyatt Earp.

Doc holiday. Jesse James. Now they were men. Real men.

(at the proprietors voice, the cowboy begins to show some agitation)

Guest: Women love cowboys. You know why. 'cause they're tough.

Prossie: $\quad$ Tough bastards alright. And we love 'em.

Proprietor: You wanna be a real man you gotta be tough.

Guest: Grit ya teeth. Take it on the chin. Spit blood. And do it all again.

Proprietor: Time you started behaving like a man. A cowboy.

Guest: $\quad$ Let's ride you bitch!

(he repeatedly slaps/punches her. He puts her back in the suitcase. Closes the lid and transfers his attention briefly to the tv. The soundscape escalates and the vacancy sign flares).

\section{Scene 7: Smoko}

(dawn light and dirty rain. The prostitutes are on a break. The suitcases become various chairs, stairs - objects on which they can sit. They speak their inner landscape into the distance. The soundscape is faint but orchestrates their thoughts).

Prossie 1. I pulled out that gun and shot him clean through his filthy mouth. Made myself disappear after that.

Prossie 2. God and the devil chase me every night. I run into them at the bottom of a Bundy bottle.

Prossie 3. My dad loved me. He did. Loved me so much we made a baby. He flogged me when he found out. Belted the living shit out of me. But that baby held on tight. Was born all twisted and broken. She's with god now. That little baby.

Prossie 4: It's much easier than thieving for a living. Besides it's the only thing i can do well. Well enough anyway.

Prossie 5: Everyone I know is either in jail or about to be.

Prossie 6: One day I'm going to be a beautician.

Prossie 7: My mother was a slut. That's what my dad'd always be telling her. Sort'a family tradition we got going on. My daughter'll be the same. 
Prossie 8: The pension's not enough to feed two kids. Yeah I got two. A boy and a girl. I thank god every day for small things.

(as one they stamp out their cigarettes and the vacancy sign buzzes).

\section{Scene 8: Neon Reflections}

(a new day. The flickering neon lights from the highway reflect the stark motel rooms. Guest 1 is utilising the suitcase as a window, peering through it to the neon strip outside).

Guest 1: It has a window, with a dirty lace curtain. A little shredded along the bottom edge. Like someone's been clawing at it.

(guest 2 is bathing the broken bloodied body of the prostitute in the suitcase).

Guest 2: $\quad$ The lights evoke impotence in men. The flickering tones whisper of open wounds in women.

(guest 3 is sitting on the clinging to the bible).

Guest 3: The wall I stare boasts a shadowed frame containing a failed artists attempt at a butterscotch beach.

(guest 4 is standing in the suitcase, as if it's a shower stall. Holding a razor blade).

Guest 4: I see that the bedspread, sheets and pillowcases are stiff, puce-stained as are the matching frayed towels on the bathroom floor. The bathroom linen soaks up the same awful secrets as the bed that $i$ will lie awake in.

(guest 5 is taking a barbie doll out of her suitcase).

Guest 5: There's a plant on the windowsill. A fern. Its leaves claw at the glass, desperate for the clean air outside.

\section{Scene 6: A Tale That's Sad But True}

(the suitcases form a double bed on which the guest and the prossie will have sex. The proprietor watches over the outcome)

Proprietor: He's seldom in town. They mostly try and catch glimpses of each other over vast distances. He thinks she looks like a kewpie doll, all eyebrows plucked and raspberry kissed lips.

Guest: $\quad$ A mirror faces the door.

Prossie: $\quad$ Too soon I will catch his reflection exiting this puce coloured room/ 
Guest: $\quad$ First we fall fiercely into each other/

Prossie: $\quad$ Yes...but first/

Proprietor: Momentarily the future beautician and the car salesman fall into each other.

Guest: $\quad$ One bed, one sink, one toilet, one wardrobe, one moment...stolen/

Proprietor: Momentarily she is beautiful. This beauty fades as quickly as the distance he travels home to his wife.

Prossie: I'm pregnant/

Guest: $\quad$ I see/

(he gets out of the bed, she smiles up at him).

Prossie 2: Gun lobbyist members rejoiced today at the birth of a bouncing baby bullet. The delivery took place in room 17 of motel chronicles.

Proprietor: The baby bullet was later found in the skull of a 14 year old prostitute who was later confirmed as being 9 weeks pregnant. When questioned by the police the occupier of the room stated:

Guest: I would never harm a child. I have three of my own.

Little girls in white dresses, as pretty as raindrops on roses.

I adore my girls. My little girls.

\section{Scene 9: Empty Rooms}

(chorus members are vandalising the space with the suitcases)

Chorus 1: Emptiness builds her home in me and her rooms echo with eternity.

Chorus 2: This room whispers to me. Words that come for me when i wake up again on my own.

Chorus 3: I walk through ordinary rooms as I get lost in my destiny.

Prossie: $\quad$ A room in motel chronicles was vandalised today.

Prossie 2: $\quad$ It is reported that the room sustained serious injuries, including the destruction of furniture, holes in its walls and blood on its carpet.

Proprietor: When questioned the room chose to remain silent and offered no comment on the ferocity of the attack. A spokesperson for the room claims that this is not the first time the room has sustained such a particularly vicious attack. 


\section{Scene 10: Losing The Faith}

(a prossie is waiting for a client. It is raining. She is using the suitcase as an umbrella. Holding it high above her head. A motel guest has spotted her. He is watching her from under a streetlight. He ignores the rain).

Guest: $\quad$ I will find the Magdalene.

Prossie: Dad hit the wall after he hit my old girl in the face with an empty bottle of rum. (she lights a cigarette). The embers of the cigarette she was smoking mashed against her teeth.

Guest: $\quad$ Somewhere in the guts of this motel I will walk on water.

Prossie: He's gone to prison and she's gone to Jesus.

Guest: $\quad$ Somewhere in the guts of this motel I will become a new man.

Prossie: I'd like to see that place...the place I grew up in.

(he moves to her and lays his forehead against hers. She holds the umbrella over his head sheltering him from the rain).

Guest: $\quad$ Faith?

Prossie: $\quad$ Yes?

(lights fade down. When the lights fade back up, the guest is laying out a crucifix shape with the suitcases. He places her on the cross and kneels to pray beside her).

Proprietor: Today a young man was reported to have lost faith. Faith, the young man claimed had been missing for a lengthy but unspecified time. He stated he had been searching in vain for faith for most of his adult life. The man stated that he fears that the disappearance of faith will lead to his further disillusionment with god. Both faith and god are now listed as missing persons.

\section{Scene 10: Vacancy 2}

(the stage is empty bare except for broken, open and empty suitcases. The proprietor enters and begins closing the suitcases and stacking them. The chorus enter one by one throughout and speak directly to the audience as prostitutes).

Proprietor: Signs back on. Vacancy. A couple of vacancies! You are all very welcome. You need a room on the corner of this side-show street! Get off the merry-goround and really let your-self loose in side-show alley? A few Hail Mary's and Hallelujah Jesus's and you'll be fine. Trust me. 
Prossie 1: Ignore the stains/

Prossie 2: $\quad$ Ignore the children crying/

Prossie 3: We take all major credit cards.

Proprietor: There's room for you, yes you with your strange ways...c'mon...just a couple of days. Relax. Double or single. Flat rate.

Prossie 4: We promise you'll find deterioration/

Prossie 5: Maybe some decomposition/

Prossie 6: $\quad$ And us. C'mon lose yourself. We can make you feel fine.

Proprietor: Unpack your pain and your shame and your lapsing faith. Just \$25 a night.

Prossie 1: $\quad$ You need some space?

Prossie 2: $\quad$ Or a little down time?

Prossie 3: Movies which are a little bit blue?

Proprietor: It's all her waiting for you my friend. So come on in! Come talk to your faith or your razor blade, or your dead little girl.

Prossie 2: We've got pillows to cry on and televisions to kick.

Proprietor: $\quad 24$ hours for $\$ 25$. Vacancy. Come dream your dreams. Cash or credit $\$ 25$ a night.

Chorus: Vacancy...vacancy...

(a very young girl walks past the sign and pauses in front of the proprietor. The rain continues).

Girl: $\quad$ I think I'm lost. Please...i can't seem to find my way home...

(the night soundscape escalates. End of play). 


\section{Research statement}

\section{Research background}

Situated in the field of creative writing for performance Motel Chronicles is an innovative post-dramatic investigation into themes associated with land/culturescape (Chaudhuri 2002, Hassall 2012) and behaviour. Unifying Hassall's research into theoretical landscape investigation with her creative influences e.g. such as Sam Shepard and the American Outlaw Poets, Motel Chronicles aims to explore culturescape experiences from sociological perspectives.

\section{Research contribution}

Motel Chronicles contributes to creative research in methodological, dramaturgical and theatrical fields. Uniquely the play transforms theoretical discourses relating to sociological determinants into cultural expression. Contributing to both theoretical discourses in urban landscape and practice-led creative expression as research the work contributes to a field which contextualises sociological conditions into an atmospheric landscape of performance. Through its unification of expressionistic form, musical structure and post dramatic design elements, Motel Chronicles extends discourses associated with urban landscape and the effect environment may have on particular psychological and physical behaviours (Goddu 2007, Casey 1998, 2002, Cosgrove 1984, 2008, Spirn 2008, Taussig cited in Leibsohn 2008).

\section{Research significance.}

Motel Chronicles is significant in creative research fields as it uniquely investigates theoretical landscape contexts as theatrical performative expression.

\section{Works cited}

Arcade, P 1999 'Career move' in Kaufman, A \& SA Griffin (eds) The outlaw bible of American poetry Thunder Mouth, New York

Chaudhuri, U 2002 'Land/Scape/Theory' in Fuchs, E \& U Chaudhuri Land/Scape/Theatre, U of Michigan P, Chicago

Cosgrove, DE 2008 [Participant in] 'The art seminar' in R Z DeLue \& J Elkins (eds) Landscape theory Routledge, New York, 87-156

Casey, E S 1998 The fate of place: a philosophical history U of California P, Berkeley

Casey, E S 2002 Representing place: landscape painting and maps U of Minnesota Press, Minneapolis

Cosgrove, D 1984 Social formation and symbolic landscape, Hutchinson, London

Hamilton, F 1999 Frozen Alley in Kaufman, A \& SA Griffin (eds) 1999 The outlaw bible of American poetry

Thunder Mouth, New York

Hassall, L 2012 Evoking and dramatising the landscape in the creation and development of a new dramatic play: Dawn's Faded Rose thesis, Griffith U, Brisbane

Kaufman, A \& SA Griffin (eds) 1999 The outlaw bible of American poetry Thunder Mouth, New York 
Learner, D 1999 'Mein Kampf' in Kaufman, A \& SA Griffin (eds) The outlaw bible of American poetry Thunder Mouth, New York

Presley, E 1969 From Memphis to Vegas. From Vegas to Memphis: Are you lonesome tonight RCA Records, Nashville

Martinovic, L 1999 Debt of blood and The outlaw in Kaufman, A \& SA Griffin (eds.) The outlaw bible of American poetry Thunder Mouth, New York

Shepard, S 1982 Motel chronicles and Hawk moon City Lights, San Francisco.

Shepard, S 1981 Sam Shepard seven plays: True west Bantam, New York

Shepard, S 1979 Sam Shepard seven plays: Buried child Bantam, New York

Shepard, S 1976 Sam Shepard seven plays: Curse of the starving class Bantam, New York

Spirn, A W 2008 'One with nature: landscape, language, empathy and imagination' in R Z DeLue \& J Elkins (eds) Landscape theory Routledge, New York, 43-68

Leibsohn. D 2008 'On the limes of landscape' in R Z DeLue \& J Elkins (eds), Landscape theory Routledge, New York, 242-46 


\title{
RMIT University
}

\author{
Stephen Sculley
}

Stringer: episode 1: A television novel

\begin{abstract}
:
Chris Stringer is an investigative journalist who has been duped into doing a story, which conceals the identity of a murderer. In attempting to find the truth, he is dragged into a web of business and political corruption. Stringer is a six-part television novel with each chapter being a one-hour episode. Episode 1 establishes the key characters and the core dramatic question; who killed Gary Morley? Stringer uses a novelistic approach to develop a multi-episode high-end television drama. This prose text utilizes literary, cinematic and theatrical elements inherent within the high-end format to present multiple storylines and complex characterisation. Through the creative writing process Stringer extends the traditional skeletal approach to series development by framing the drama as a television novel. The outcome for this approach is twofold; firstly as a way of developing a high-end narrative with complex characters, themes and counter themes and secondly as a new way of valuing the work of the screenwriter by removing it from the industrial hierarchy of current script development and retaining the screenwriter's original authorial voice in book form.
\end{abstract}

\section{Biographical note:}

Stephen Sculley is a Doctoral Research Candidate at RMIT University School of Media and Communication. He is an actor and creative writer with extensive experience in theatre, film and television. He holds a Diploma in Dramatic Arts and Graduate Diploma in Film and Television at Melbourne University, Advanced Diploma in Professional Screenwriting, BA Creative Writing with Distinction, and BA Honours in Media and Communication, at RMIT University.

Keywords:

Creative Writing - Screenwriting practice - Screen idea development - TV drama 


\section{EPISODE 1}

The high beam of a Ford Ranger pick-up shone on the car in front highlighting the bumper sticker: Vote More Mobility - More Freedom. Morley looked into the rear view mirror ... the Ford accelerated and rammed the car causing it to skid across the white line and broadside into the gravel apron. Morley spun the steering wheel left, right, left as sweat poured from his brow. He was panicked his bulging eyes and shallow breathing a dead giveaway. The Ford bumped a second time and the car catapulted forward, Morley stabbed the brakes - HARD, the car flipped on its side and slid into the scrub with metal screeching and sparks flying. The pick-up stopped stillness except for the ominous idling of the engine. Morley opened the door and his short, full frame fell onto the ground. He raised his arm to shield his eyes from the lights; doubled over with blood running from his temple he limped to the side of the road. In a desperate attempt to escape he climbed the fence but his trouser leg snared in the wire. The engine revved low at first then HIGHER and HIGHER. The Ford had nowhere to go but forward; gears crunched, brakes released and the pick-up rolled Morley in barbed wire and dust. In a final statement the truck reversed: tyres inked in blood, revealing the body - LACERATED, MANGLED, DEAD.

\section{FLASH FORWARD - 6 MONTHS LATER}

Northside Media was an independent online news site. They profiled and investigated politics, business, current affairs and news of the day. Northside was located in an old renovated textile factory in Northcote.

Over a dozen staff raced around in a state of continuous excitement. There were deadlines to be met, copy to be revised and images to be uploaded. From copywriters 
to photographers, IT people and Journos, Northside was dedicated to networked news and breaking stories. The open plan office had a large screen bolted onto the distressed red brick wall. News had just broken ...

\section{CONVICTED MURDERER, DALE WILSON \\ LOSES APPEAL.}

CHRIS STRINGER was the lanky and unshaven head writer who wrote his opinion on a regular basis. He was one of the reasons Northside had gained traction with a strong subscription base and social media following. As he watched the television he typed:

Wilson's appeal thrown out of court: What can you say about a society that is driven by economic necessity? When ambition is no more than a knife in the back or in this case a drunken killer behind the wheel. The murder of politician Gary Morley highlights the degree to which money means everything. Convicted murderer, Dale Wilson had a lot to lose ... greed and booze will now see him in gaol for a very long time...

Outside, the city was caked in dust: the wipers of a car streaked across the windscreen, a pedestrian held a handkerchief to her mouth and an unkindness of ravens took flight. The city was a network of roads, freeways, and trains linked in a web of imperfect order. This was a first-world metropolis bursting at the seams - a city driven by self-interest and run by Fat Cats.

From the steps of Parliament House to the Docklands and the Crown Casino, traffic pushed and crawled at a hopeless pace. 
A Black Chrysler rose from the underground car park at the base of the Docklands apartment. It inched forward in peak hour traffic, swamped in the murky haze of a carbon monoxide cloud.

Honey sat with Damir.

She had her phone on speaker. 'No is not an option Don.'

Don's whinny voice could be heard through the phone, 'Honey, I'm doing everything I can.'

'That doesn't move things along does it?'

Their driver was Sammy, his porcine belly pressed hard against the steering wheel. He honked the horn.

'Where are you?' asked Don.

'In traffic, I'll see you tonight.'

Honey took out a cigarette and Damir provided the flame. She inhaled and expelled a cloud of smoke, which quickly filled the car. She opened the window. A tin rattler with a visy vest and a gammy leg hobbled between the stagnant traffic. The tin had a multiple sclerosis sticker wrapped around it. Honey waved the guy over. She handed him fifty dollars then butted her cigarette in the tin and said, 'Nothing's for free' and the car moved off.

\section{CROWN CASINO 5/4/2015 \\ 'MEDIA HOUNDS' SLAP EACH OTHER ON THE BACK.}

Inside the Palladium at Crown, Chris was pissed off at having to attend the Australian Media and Journalism Awards. His rosy cheeked wife, TALIA and nine year old stepson, AARON sat at the Northside table. Chris kept his arms folded, jaw clenched 
and his attitude on display. Sitting with them was journalist JEAN SAYER and Chief Editor HARRY ROSENBERG. Aaron sulked and sucked his fizzy drink. Talia clasped Chris's hand. The nerves were palpable at the Northside table. They gulped their wine and watched intently. Chris's petulance gave way to anticipation - he chewed his lower lip while Jean smiled inanely. Harry loosened his tie and kicked his shoes off as a way of containing his excitement. Aaron tugged at his mother's arm. 'I need to go to the toilet.'

'Can't you wait?'

'No, I don't want to go by myself. Hurry.'

Talia, loving helicopter mum and best friend to Aaron disappeared to the washroom, much to Chris's dismay. He looked across the room and caught the eye of Morley's widow JANE. She stared back - her thin lips smiled momentarily then retracted - the sorrowful widow.

The MC, ABC Journo TONY NATALI introduced the contenders. 'The finalists are Bruce Shamrock and Erica Austin - Southern News, Edwin Sarjan and George Pescano - ABC Dateline, Harry Rosenberg, Chris Stringer and Jean Sayer- Northside Media.'

Tony then introduced DON McALPIN, Minister for Infrastructure and the Arts. Don glided across the stage and Natali adjusted the microphone to account for Don's diminutive stature. 'Thank you, Gary was a personal friend of mine and I am honoured to announce the winner in what has been a dark event in our political life. The task of bringing justice to the travesty that befell a most trusted and senior Member of Parliament has been a powerful collaboration between the police and the 
media. The winner for Best Investigative Journalism is ... Harry Rosenberg, Chris Stringer and Jean Sayer - Northside Media.'

\section{APPLAUSE}

Harry punched his fist in the air. Chris looked to the door but there was no sign of Talia or Aaron. Video footage with voice over played on the large screens that flanked the stage.

\section{ROAD KILL: THE MURDER OF GARY MORLEY}

The vision showed protestor Dale Wilson at a rally heckling the Minister for Infrastructure, Gary Morley. Serial pests LYNDON, RUBY and GROMMO were front and centre. Grommo wore his trademark Khaki jacket and red bandanna and held a megaphone leading the mob in a vociferous attack. Morley left the stage under pressure from the crowd. Deep in the mob a young woman approached Gary, her hand grabbed his for a short moment then released.

Wilson sat in his cell watching the A.M.J.A event on his small TV. His face was rock hard. He thought about that day at the rally and how the events of the last 6 months 
had landed him in a high security prison. His memory of that night was blurred. True - he had been found behind the wheel. It was his pick-up truck that crunched Morley into the dirt. Did he kill Morley? He still couldn't believe it - he shook his head in dismay and switched off the television.

Chris had watched the footage many times; filming, rough-cut, final cut but now he saw something and it didn't feel right.

\section{FLASHBACK \\ WOMAN STROKED MORLEY'S HAND? MOMENT OF REALIZATION.}

Harry \& Co made their way to the stage with Harry in his socks. Chris tried to crack a smile as he stepped onto the stage, he accepted the Perspex award and held it in the air as he looked to the empty table and for a moment his disappointment could be seen. He stared blankly, Natali re-adjusted the microphone and Harry said. 'I just want to thank Jean and Chris ... I want to acknowledge Gary Morley's family in particular Gary's wife Jane, who has suffered incredible loss. Journalism - has a role to play beyond phone hacking and celebrity meltdowns. Real people, real stories. More power to independent media.'

Chris, Jean and Harry left the stage as Talia and Aaron rushed back into the room. Talia downed her eyes sheepishly and took her seat.

She leant across to Chris and gave him a kiss. Aaron brought the straw to his mouth and sucked the bottom of the glass dry. SLURP.

The A.M.J.A. proceedings were thankfully short as the real show was about to get under way - the pressing of flesh and flashing of teeth. The event was full of media 
people and minor celebrities. Don circled the room shaking hands, smiling and waving. It was a good publicity opportunity, McAlpin Attends Media Night-Supports the Arts. For a 'late forties' Don carried himself with certain aplomb. He had a head full of hair and a boyish charm that wooed girls ten years younger but from Don's point of view there was a downside. It was his height. He suffered from small dog syndrome. The media referred to him as The Poodle.

People mingled - flamingos on a lake. Chris stood by the aspidistras framing the exit. Jean approached. 'I thought Harry was going to explode.'

'Awards are good for business...' said Chris. He paused. 'The footage of Morley ... at the protest rally?'

'What?' asked Jean.

'I saw something.'

'What?'

'When Morley stepped off the stage a woman grabbed his hand.'

'So what?'

'Well Morley was married.'

'Was he having an affair?' asked Jean.

'Maybe ... been known to happen.'

Harry slapped Chris on the back. 'There's a lot of buzz - all good.'

'Was Morley having an affair?' asked Chris.

'It was never raised in the court case.'

'You knew about it?'

'No, we would have picked it up if it's true.'

'I'm not sure but the footage of Morley with the girl looks a little NQR.' 
Harry stood up. 'Okay, well let's not rush to any conclusions.'

'You're right.'

'It's a bit of a worry.'

'You worry too much.'

'Talk about this later,' said Harry.

Don approached Honey.

'I'm not very happy with you,' said Honey.

'Don't be so petulant the wheels of fortune are turning and in our favour.'

'Cut the spin and push it through.'

Yelling could be heard across the room. Grommo in a tight fitting waiter's jacket jumped onto a table. 'Stop the Tunnel Now!' He was dragged from the table but not before he threw hundreds of flyers into the air ... floating gently to the floor: SAY NO TO CITY CONNECT - VOTE GREENS. Grommo was dragged from the room, screaming the slogan and lunging at Don McAlpin yelling, 'No trucks scumbag!'

Damir moved close to Honey’s side as the fracas subsided.

'It's alright get the car, I've had enough of this swill,' said Honey.

MARLA DAVIS, doe eyed, red hair and dressed in a grey pencil skirt with matching jacket stood next to Chris.

'That was dramatic,' said Marla.

'The story that keeps giving.'

'Do you think it will go ahead?'

'They'll push it through before the election.' 
They looked across the room and saw staff picking up the flyers and putting them in champagne buckets.

'With anyone?' asked Chris.

'Jake, he's stationed at St. Kilda Road. Think we could meet someone else other than cops ... like real people! Great job on the Morley story.'

'Thanks.'

'Haven't seen you round the courts,' said Chris.

'I'm over at the media liaison.' Marla gave a cheesy smile. 'Call, we're here to help.' She turned to find her guest Jake the cop who waved from across the room looking like a shag on a rock. Chris finished his drink and saw Aaron. He moved towards the side-table.

Aaron jammed another canapé into his mouth and washed it down with a Pepsi.

'How ya doin'?'

He replied, 'I'm tired.'

'Where's your Mum?'

'She's over there talking with Jean.'

'Let's go,' said Chris.

The combo started to play their Latino bracket. It was Don's cue to bust a few moves. Photos of the politician and the weather girl dancing were destined for the social pages and they knew it.

Chris, Talia and Aaron sat in the back seat of the taxi with Aaron in the middle. 'Are you okay?'

Chris retorted. 'Are you okay? So much for thanking my family.' 
'Oh, come off it.' She turned her head acknowledging Aaron, 'not now.'

They sat in silence as the taxi turned left into Brunswick Street.

Sammy parked the Chrysler at the entrance of the Docklands apartment and Honey disappeared behind the smoky glass foyer and into the lift. The doors gently closed.

Damir and Sammy kicked back at Damir's apartment, two buildings away from Honey. The large screen played loud Croatian heavy metal music as Sammy smoked a foil and left a deep impression on the plush lounge. Damir started pumping iron. 'You should take more care of yourself.'

'Whadda ya think I'm doin' bro?'

'Where I come from we don't tolerate amateurs.'

'Where I come from ...'

'Shut-up Sammy it's okay relax. You like this music?'

'Yeah it rocks.'

'You bet it rocks - HARD.

'If you say so, I'm goin' to the club wanna sit in?'

'Later.'

Talia pulled the doona up to Aaron's chin and Chris stood in the doorway. The 'parents' stood and for a moment there was a feeling of 'happy families'.

Chris cracked a bottle of Di Georgio. He poured a celebratory drink and in the silence their eyes softened. He opened his arms and Talia felt his warm embrace. Her dress slipped away as they pushed against the cupboard. They retired to the bedroom with bottle in hand. The queen size bed filled the bedroom and Talia's plump naked body 
spread across the sheets. She rolled onto her side and polished off her glass. Chris gently stroked her thigh but Talia grabbed his hand and made him stop. 'I don't think I can do this anymore.'

Talia lay on her back and stared at the ceiling for an inordinate amount of time thinking, somebody say something!

Chris said. 'I'm gonna take a shower.'

Aaron switched on his night-light and vomited onto the floor. Deeply ashamed he threw a towel on the mess and hid under the doona.

The following morning Chris sat at his computer and trawled the old files from his investigation into the Morley murder. He found the footage of the City Connect rally and slowly reviewed it confirming what he had seen the night before.

Talia called out to Aaron. 'You're going to be late for school.' Aaron called from the bathroom. 'I'm tired.'

Chris turned up the volume on the television in the kitchen. It was Don McAlpin giving a doorstop interview as he entered Parliament House. He was surrounded by a voracious media pack and protestors chanting and holding placards.

We need a tunnel like we need a hole in the head. No Trucks. Trains not tolls. Reporters thrust their microphones towards McAlpin. 'Is the link going ahead?' 'Absolutely. No more questions thank you.' 'What happened at the A.M.J.A. last night?' 'I had a great night.'

Talia grabbed the remote and turned the TV off. 'Hello! Can you pick up Aaron after school?' 
'What? Yeah sure.'

'Can you take an interest in anything other than yourself?' Chris looked at her. 'Don't answer that. Aaron hurry up we're gonna be late.'

Aaron appeared from the bathroom and Talia said. 'You alright sweetie?'

'Yeah.'

Chris took a screen shot of the girl and emailed it to Marla Davis, requesting ID information. The phone rang - it was Harry, wanting to capitalise on winning the A.M.J.A. 'We need to do a follow up story about the truck industry.'

'Something stinks about the Morley story.'

Harry cautioned him. 'You're still worried about the other woman? He probably was having an affair. He was a politician. I guess we have to think about his family - will it serve any purpose to drag it up? I think the story is a done deal mate.'

'I wanna track down the girl.'

'Chris! Stringer!' Harry took several deep breaths and thought, 'Fuck, it's never easy.'

The Speaker slammed his gavel on the wooden block. 'Order, order in the house. Would the Honourable Member for Pascoe Vale please refrain from interjecting and allow the Minister for Infrastructure to continue.'

Don nodded and puffed his chest forward. 'As I was saying, Mr. Speaker the City Connect project is in the final stages of securing the tender for stage one of the proposed development ...'

'No way, you've got no right,' came from the floor.

'I will ask the member for Pasco Vale to leave the chamber for a period of one hour.' 
Don continued. 'Mr. Speaker my department is currently reviewing the tender submissions and will make a decision. A decision I might add that will benefit, will absolutely benefit the people of this great state of Victoria for generations to come.' Cries approval could be heard. 'Here, here.'

Honey was standing in her apartment overlooking Port Phillip Bay. Don was sitting on the couch drinking tea.

'I suppose you think you looked good this morning standing on the steps.'

'I like to think I look good at all times.

Honey turned to face Don which prompted him to say, 'I'm sorry things are moving slower than I'd hoped.'

Honey sat next to Don. Her hand circled his face then slapped it hard.

Don said. 'Some people want the local mob, DB Constructions,' he raised an eyebrow, 'due process.'

Honey grabbed Don's tie and pulled him close. 'I'm not interested in due process.'

Chris met Marla at the Police Media Unit.

'I got the pic but there's not much to go on. What about a name?'

Chris's mobile rang. It was Talia he declined the call. 'She's about mid-twenties, dark hair, Chinese. Maybe Young Liberal?'

'I'll check the database see what we can come up with.'

Outside St. Vincent's hospital patients sat in wheelchairs and savoured their ciggies their last grab for control before being wheeled back into the wards. 
The lift doors opened and Talia nervously stepped onto the ward. After speaking at reception she waited. The doctor approached - Talia desperately trying to read his face. They exchanged a few words. She entered the room and found Aaron sitting upright in bed with a saline drip connected to his arm. Talia hugged her. 'You're gonna be alright baby.'

Chris arrived at the hospital. Talia felt relief at seeing him but it quickly turned to anger. 'Where were you?'

'Work. Is he alright?'

'Vomiting at school.'

'Something he ate?' asked Chris.

'Diabetes,' said Talia, then she bawled her eyes out. They sat in the waiting room and Chris began to pace the floor, he looked at his watch. Talia asked, 'Do you have to be somewhere?'

'No, no I'm here. When can we see him?'

'He’s asleep.'

He continued to pace and check his phone.

Talia picked up a teddy bear from the toy box. 'Just go.'

'I had planned on going to Barwon to see Wilson.'

She threw the teddy bear and it landed at his feet.

Chris took the Western Ring Road. It was adorned by industrial sculptures and architectural textures - multi-lane freeways with crossovers and lane changes.

On arrival he was led through security into the visitors' area. Wilson fronted with a black eye and bruised face. 
'What do you want?'

'Ask a few questions.'

Silence from Wilson.

'Did you know Morley was having an affair?'

'News to me.'

'Did you ever see him with a Chinese girl?'

Wilson thought for a moment. 'I couldn't say.'

'On the night you killed Morley ...'

'I didn't kill Morley.'

'You don't remember because you were drunk. Come on, you were found behind the wheel of your car, you crunched him into the dirt. Forensics matched the paint from your car to Morley's.

'I got a call from Morley's secretary, she said he wanted to meet at the Little River pub talk about a compromise over the Parkville section.'

'And your house?'

'That wasn't an issue in fact I was going to do okay out of the deal. He wasn't there. I had a beer and that's the last thing I remember.'

'You didn't like Morley?'

'Of course not he was a snake ... doesn't mean I killed him. Fuck, I don't know. I was spiked.'

'Nobody believes that.'

'I was guilty before it got to trial thanks to you.'

Chris stood in the car park and called Talia. No answer. He rang Harry.

'Where are you?' asked Harry. 
'I'm at Barwon.' Silence. 'Not Wilson? I thought we agreed to let that go, mate, there are other stories out there. We won the prize - I'm worried. You have to know when a story has run its course.'

'You want Wilson to rot for something he didn't do?'

'Of course not, but Morley having an affair doesn't change anything.'

'We don't know that.'

The sun, set over the You Yangs as trucks and cars vied for the optimal lane on the Geelong freeway.

Wilson was stretched out on his bunk. His hands cupped behind his head. The meeting with Chris prompted thoughts about the night of Morley's murder.

\section{FLASHBACK}

Wilson arrived at the Little River Pub

He ordered a drink and looked at his watch.

\section{INSERT}

Blurred montage: Sammy, Damir, trees, and moon - all in a swaying sickening motion.

When Chris arrived home he found his suitcase leaning against the veranda wall. He stood for a moment not sure how to respond. He inserted the key in the front door but had second thoughts. He grabbed his belongings, turned and jumped into his car. 
Harry was asleep in the upstairs living area. The ground floor comprised of a large table, a few digital cameras, tripods and several computers. The place was dark he climbed the stairs to the living area. 'Harry, it's me.' No answer. Chris switched on the light and found Harry, naked asleep on the couch.

Harry bolted upright. Chris responded, 'Fuck, put some clothes on.' Harry was awake now. 'What are you doin' here?'

'I saw Wilson. Nothing.'

'I could have told you that.'

Chris grabbed a couple of beers from the fridge while Harry pulled on his pants.

'I didn't know you were a naturalist.'

'You mean naturist. And I'm not.'

'You just like to free-snake it?'

'I went to the doc and she said I have anxiety issues.'

'I could have told you that.'

'I get chest pains and nausea ... it's fucked.'

Chris was about to sit on the couch and then thought better of it he sat in the designer winged chair and got stuck into the beer. 'What's your problem?'

Harry said, 'I just want to get my gear off. The doc gave me some Zoloft but it's a bad mix with whiskey. I must have passed out.'

Chris pondered for a moment and then noticed Harry's shoes by the wall. 'You just get a feeling?'

Harry nodded, shamefully.

They sat quietly. 'You're joking, right?'

Harry popped his beer and drank.

More silence. 'It's good you're seeing the doctor, that's good,' said Chris. 
They drank throughout the night and Chris curled up in the chair.

The following morning Harry came downstairs fully clothed and Chris was at the computer. 'Find anything?' asked Harry.

'Wilson said he received a call from Morley's secretary ... from a mobile? Did we check with his secretary?'

'No. At the time it seemed like Wilson was it. Sounds like we missed some of the finer points. But we're not cops we're journos.'

'How did you know Wilson's house was up for demolition?' asked Chris.

'I can't remember ... public record?' The coffee started to percolate. Harry turned and stepped on Chris's bag. 'Shit.'

Chris pulled out the broken Perspex award.

Harry grabbed it. 'No, I fucked it up.'

‘Superglue?' said Chris.

Jean arrived. 'Public Transport don't ya just love it.' She rummaged through the shelves, grabbed a camera bag, tripod and batteries. 'Batteries charged?'

Harry and Chris shrugged their shoulders.

'McAlpin is giving a press conference at ten!'

Harry nodded his head. 'Find what he's on about.'

Jean arrived with the camera bag slung over her shoulder. She took a seat with the other journos as Don McAlpin walked towards the podium.

'Our future relies on infrastructure and the City Connect project will be one of the most ambitious projects this city has seen in decades. In making my decision I have shown no fear nor favour - this project is in the best interests of the community.' 
'What about the tender?'

'The truth of the matter is - we're working our way through the contracts, Leasehold have pulled out and we have two others, DB Construction and UK Lester Group.' 'Didn't your predecessor Gary Morley favour DB?'

'Thank you' and he did a 'Clive Palmer'. Exit stage left. His voice could be heard down the corridor. 'I have an important lunch date.'

Jean noticed the Member for Pasco Vale, Allen Harcourt at the back of the room. 'Allen, hi Jean Sayer from Northside Media any comment?'

'This is a sell-out, McAlpin has the chance to do the right thing but he's pushing ahead. This project should be delayed until the election.

City Connect should be taken to the people. McAlpin has no right to sign any contracts. It's being rushed through and you have to ask yourself - why?'

Chris met Jane Morley at the Yarra Bend Boathouse. The geese and ducks waddled in and out of the water as if they knew what they were doing.

'Thanks for seeing me.' Chris opened his laptop and played the scene where the Chinese girl grabbed Morley's hand.'

Jane started to cry. 'I knew about it. I wanted out but Gary begged me to stay.'

'What are you saying?'

'Gary was having an affair.'

'Do you know who she was?'

'Katherine Cheng - she was a prostitute.'

'Did she have anything to do with Gary's death?' 
'I found out he was seeing her at a B\&B on the Little River Road, where they found Gary. He's dead that's all I know.'

Jane left and Chris threw breadcrumbs at the ducks. He rang Marla. 'Her name is Katherine Cheng. She works as a hooker.'

Marla sat at the computer and brought up a list of Chengs. 'Okay, I've got a K. Cheng in Epping, Croydon, Richmond ... Interstate?'

'Thanks send the list and I'll do the legwork.'

Chris walked into Neptune Lane and was met with a funeral procession. A coffin pasted in white and yellow holy paper was carried by six pallbearers and placed on the side of the road. The small crowd of mainly Chinese stood respectfully while gongs and bells were sounded. The coffin was then lifted into the hearse.

Michael Cheng, his sister Katherine and their elderly mother Lily rested their heads on the vehicle for a moment. Michael led the group, holding a lit joss stick.

Katherine stared at Chris and for a moment their eyes met. The procession moved solemnly as mourners tried to subdue their grief. Chris watched as the hearse slowly passed by. A lady stood at the gate of her house and told him that old man Cheng died. She pointed to the family. 'That's Lily Cheng and her son Michael and his sister Katherine. She's trouble.'

Once the hearse drove away Chris approached Katherine. 'I'm Chris Stringer from Northside Media.' He handed her his card. 'Did you know Gary Morley?'

'I don't know what you're talking about, leave us alone.'

Michael Cheng saw his sister in distress. 'Who are you?'

'Chris Stringer, Northside Media.'

'My sister is upset?' 
'I just want to ask a few questions.'

'Fuck off.'

Chris nodded apologetically and made a strategic departure. 'Maybe another time?'

Pink clouds morphed into grey streaks and the sun fell in the Western skies.

Night - Heat - Insects buzzed around the entrance light of the VIP club.

Katherine sat at the bar. She was plastered.

'You're not supposed to drink on the job,' said Damir.

'I buried my dad today so who gives a shit.'

'A nice girl, such a filthy mouth.'

'I told Honey I wasn't on tonight okay.'

'Sure, sure, drink.'

'This came today,' Katherine handed Chris's card to Damir. 'Some journo asking about Gary.'

'What did you say?'

Katherine slurring her words, 'I didn't tell him anything ... no I told him to fuck off!' Damir nodded. 'Good.'

The red dust rolled across the city skyline as Chris stared at the brown stagnant water of the Yarra. Marla arrived. 'I asked around and you might be onto something.

Katherine Cheng had $\$ 250,000$ deposited into her account about a year ago.'

Chris jumped on this piece of info, 'Who made the deposit?'

'Came from an account under the name of The Institute for Free Enterprise.'

'Where do they come up with this shit?' 
'It's set up as some kind of not for profit foundation. Headed up by a guy called

Marcus Agrippa.'

'Who's he?'

'A Roman general 63-12 BC. That's all I've got at the moment.'

'Thanks.'

'You should relax drink more. I'll call if I know anything else.'

'Thanks again.'

Honey sat behind the desk at Pieter's transport when Damir called, she picked up the phone and Damir spoke. 'Kathy Cheng.'

'Yes, I know her Daddy died.'

'The journalist was at the funeral.'

'What! Which journalist?

'Stringer - Kathy said he was asking about Morley.'

Honey said. 'She knows too much.'

'I'll take care of her no problem.'

Katherine was tanked, she sat in the passenger seat and her head lolled back onto the headrest. 'Where are we going Dammy?'

'Need to lay low for a while. I'll take care of you.'

'You're a good man. I need to tell my brother he'll be worried.'

'You can call once we get to the safe house.' Damir played his heavy metal music - a ballad and Kathy lit a smoke.

'I won't say anything.'

'What's to say?' 
'Nothing.'

They drove out onto the Calder highway the M79 towards Bendigo. Damir pulled into the scrub at Ravenswood and stepped from the car, 'wait here,' using his phone torch he scanned the area. The beam came to rest on a piece of corrugated iron.

Katherine saw Damir lift the sheet and the penny dropped. She ran from the car and into the bush.

'Katherine it's okay, no problem,' said Damir.

She ran, pushing her way through the scrub until she fell into the Buck Eye Creek. Damir stood listened and followed the sound of the splashing water. Katherine was out of breath she stumbled in the creek and crawled her way up the bank. Weeping and terrified she staggered through the darkness. Damir crossed the creek and followed. She hid behind the tree as he edged closer. She couldn't contain her fear and pleaded. 'Please no, please I won't say anything.

She screamed 'No!' Damir lunged and grabbed her by the throat.

Damir's phone started ringing and in a moment of distraction Katherine kicked him in the groin and he doubled over. She made her escape into the dense bush.

Damir answered his phone.

'Where are you bro?'

'Get up here now you fuckwit ... the mineshaft.'

Damir spent the night wandering through the scrub. Mosquitos left bites all over his face. Sammy drove to the mineshaft and waited. He woke as the sun rose and then honked the car horn. A flock of Galahs took flight. Damir followed the sound and appeared from the bush a complete mess.

'What happened?' 
'I blame you, you fat prick!'

'Whoa bro I dunno what you're talkin' about but you can't speak to me like that.'

'You fuck me over like that ever again and I'll cut your heart out and throw it to the dogs. Katherine is somewhere ... find her.'

Damir arrived at Honey's apartment.

'We have a problem. She got away.'

Honey's face hardened. 'She what?'

'It was dark Sammy is up there now looking for her. Don't worry we'll find her.'

Sammy smoked a foil. He clicked his MP3 player and reclined in his bucket seat.

Chillout sounds of electronic hip-hop wafted through the trees, a far cry from Croatian heavy metal.

Katherine's brother Michael had been trying to call her. He stood at the window of the family home and left yet another message.

Jean sat at the computer and uploaded the footage of McAlpin onto the Northside website. 'Can you write some copy on McAlpin?'

Chris sat opposite the large trestle table. 'Like what?'

'You're turning into one of those people that answers a question with a question.'

'You want me to write something about McAlpin?'

'There you go again.'

Michael Cheng opened the door. 'Looking for Chris Stringer.' 
'Yeah.' Chris was pleased to extricate himself from the arduous task of writing something interesting about McAlpin.

'Have you seen my sister? Did she talk to you?'

'No don't know anything about it. What's the problem?'

'I've been trying to contact her it's not like her not to call me.'

'Come in, coffee? Sorry about your father. Maybe Katherine is having a bit of quiet time.'

'Something's not right. She went to the club and they haven't seen her.'

'What club?'

'VIP club in West Melbourne.'

'Okay, I'll look into it. What do you know about her relationship with Gary Morley.'

'She hung out with him. She said it was a business deal.'

Chris stood out the front of the VIP club - a small entrance with an olive canopy and steps leading to a solid black door with a gold knocker.

It was a brothel with a small bar laced with fairy lights. Girls sat in mock antique chairs and reclined on divans wearing lace and satin.

'Hi babe. How ya doin'? Can I get you a drink? See anything you like?

'Looking for Asian.'

'Sure,' she called out, 'Lily!' In a softer voice she said to Chris, 'Lily is Thai.'

'Thinking more Chinese.'

'You are particular. Take a seat I'll get you drink and I'm sure we can work something out.'

No sign of Katherine and he knew too many questions would lead to fewer answers. 
Damir sat upstairs surrounded by monitors, which covered the entrance and bar area and some of the rooms. He sat with his feet on the desk and the speakerphone on. 'You know the mineshaft. She has to be somewhere near there.'

'I've been lookin' bro nothin'. I reckon she hitched a ride on a truck she could be in Sydney.'

'I don't need you to tell me where she could be. I need you to find her. Watch her brother's house. She'll call her brother. Chinese they are fucked up about family.' Damir looked up at the monitor and saw Chris sitting at the bar.

He routed the phone to Honey at her apartment. 'The journalist.'

'What?' asked Honey.

'He's here at the club.'

'Send him a message.' Honey ended the call and threw the phone onto the coffee table.

Marla ordered a boutique cider and Chris stuck with whiskey. The L-bar was a cosy club where people could talk. They sat in the corner surrounded by Chinese lanterns and Tretchikoff prints.

'I had a visit from Katherine Cheng's brother - Michael. He's worried - hasn't heard from her since yesterday.'

'Doesn't sound too bad.'

'Reckons she works out of a brothel in West Melbourne called the VIP Club.'

'Classy.'

'I went there.'

'You have all the fun.'

'It wasn't fun I asked for 'Chinese' and she was a no show.' 
'You sure you weren't in a restaurant?'

Chris's face went blank.

'I'll make a few calls but it's a bit early to be putting her on missing persons list.'

'Okay.'

Chris finished his drink and waved for more.'

Marla opened her notebook. 'The Institute for Free Enterprise receives anonymous donations. No address just a P.O. Box. Money goes in and money goes out.

'Marcus Agrippa paid Cheng?'

'Well, the I.F.E. paid Cheng. It could be legit.'

'Paid her for what?'

Marla took a sip of cider.

Chris answered his own question. 'Paid her to sleep with Morley?'

It was a warm night with a light shower making the air sticky and humid. They stumbled towards the Northside office, Chris was more tanked than Marla, and he tripped on the uneven footpath. Marla hailed the approaching taxi. She opened the door and slid across the back seat. 'Thanks for the drink.' The taxi disappeared. Chris continued to walk. The lights of a Silver Lexus SUV shone in his direction and it came at him in a flash. The car mounted the footpath and he realised he was the target. He was too drunk to recognize the hooded Damir behind the wheel it swerved and hit a wheelie bin that subsequently pushed Chris against the wall of the L-Bar. He slumped forward dazed and confused then hit the ground with a heavy thump.

$$
* * *
$$

\section{An ambulance arrived at St.Vincents. Chris was wheeled into emergency.}


Grommo chained himself to an earthmover as protestors chanted Trains Not Trucks.

\author{
Sammy parked his car in Neptune Street and \\ watched the Cheng house.
}

\title{
Honey gathered the girls at the VIP Club. Most of them are crying.
}

End of Episode 1 


\section{Research statement}

\section{Research background}

Drawing on academic research in the field of screenwriting studies and practice, this work is inspired by the current debate about the value of the unpublished screenplay and the provenance of the screenplay as it moves through the industrial stages of development. Informed by Price (2010), Macdonald (2013) and Barthes (1971), this creative practice research synthesizes screenplay and novel with the intention of retaining the screenwriter's authorial expression in book form i.e. a 'television novel', a prose text for the imagined screen work.

\section{Research contribution}

Stringer contributes to the emerging area of screenwriting studies by challenging the accepted orthodoxy of screenplay development. By combining screen language and a plain modernist prose writing style, this work explores the potential of the 'television novel' as a stand-alone text with embedded information for screen development.

\section{Research significance}

This work draws on literary theory and screenwriting studies to create a 'television novel'. It explores the screen idea as a literary object and acknowledges the ontology of the work in and of itself regardless of a completed screen production. This innovative approach privileges the screenwriter and text through the separation of conception and execution and seeks to offset the problem of what Maras (2009) calls the 'vanishing screenplay'.

\section{Works cited}

Macdonald, I 2013 Screenwriting poetics and the screen idea Palgrave Macmillan, Hampshire Maras, S 2009 Screenwriting: history, theory and practice Wallflower, London

Barthes, R 1971 'From the work to the text' in DJ Hale (ed) The Novel: an anthology of criticism and theory 1900-2000 Blackwell, Oxford, 235-241

Price, S 2010 The Screenplay: authorship, theory and criticism Palgrave Macmillan, Hampshire 


\title{
RMIT
}

\section{Stayci Taylor}

\section{Mounting the Men's film festival: a mockumentary web series Webisode 1: Power cut}

\begin{abstract}
:
This pilot webisode opens with an interview between two women, a filmmaker and an entertainment reporter. This is revealed to be a scene from a comedy film by rising Hollywood star Marty Madden - who exists in a world where our familiar gender roles are reversed. Marty in turn has reversed the roles of his world, thus presenting us with a version of the world we know as if it were an imagined satire. The context is the opening night of a Men's Film Festival, the brainchild of organiser Andy Lederman, whose journey through the week of his festival provides the arc of the series. Mounting the Men's film festival is set in a world where male filmmakers bristle at being called 'male filmmakers', where men are tired of being asked how they balance work and family and where women might take their privileged position for granted. As part of wider doctoral research into female perspectives in screen comedy, particularly the relationships between comedy, point-of-view and gender in dominant screenwriting models, this script speaks to the satirical device of using gender switch narratives, and puts into practice scholarly questions around the benefits and limitations of this approach.
\end{abstract}

\section{Biographical note:}

Stayci Taylor is a $\mathrm{PhD}$ candidate in the School of Media and Communication, RMIT University. A playwright and screenwriter, she has written for broadcast in New Zealand since 2003, credits including two comedy series, and the award-winning bi-lingual serial drama Körero Mai. She has worked as a consultant, script editor, storyliner and series creator, and currently teaches undergraduate screenwriting at RMIT. Stayci's previous publications include 'Arrested Development: Can Funny, Female Characters Survive Script Development Processes?' (Philament: an online journal of the arts and culture), and (with Craig Batty) 'Interrogating Writing Practices: Perspectives from the Screenwriting Industry' in Writing in practice: the journal of creative writing research.

Keywords:

Creative Writing - Screenwriting - Gender - Comedy 


\section{Power Cut}

\section{The Characters}

ANDY LEDERMAN - The hardworking, enthusiastic and somewhat over-functioning director of the inaugural Melbourne Men's Film Festival. Though an aspiring filmmaker himself, and with a degree in Cinema Studies, Andy's strengths lend him to organisational roles and he has accrued a remarkable number of committee credits for his thirty years.

MARTY MADDEN - Charming and self-deprecating experimental filmmaker turned Hollywood rising star at the age of 24, Marty's charmed ascension in a women's world has not required him to compromise on his integrity - at least, not yet.

TROY MILLAR - 45 and of ambiguous sexuality, Troy is a rich, right wing and incredibly successful writer/director working out of Hollywood.

AMY AND JULES - Posturing and patronising house technicians at Andy's local independent cinema.

Others include volunteers, festival attendees, filmmakers, technicians and Marty's onscreen characters, Trina and Jenna. 


\section{Webisode 1: Power Cut}

1. INT. TV STUDIO - DAY

On the set of a Hollywood entertainment show, JENNA interviews TRINA.

An image of TRINA, brandishing a statuette (which looks a bit like an Oscar with breasts), hovers on a screen behind them.

JENNA

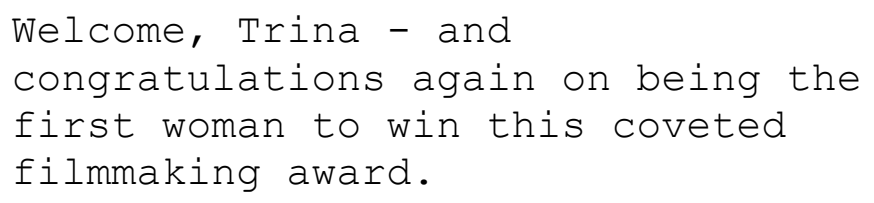

CROWD LAUGHTER (MOSTLY MALE). However, neither woman is aware of an audience so the effect is a little surreal.

\section{TRINA}

Thank you, it's an honour.

Leaning in...

\section{JENNA}

You must be proud to be such a role model for other female filmmakers.

CROWD LAUGHTER (MALE) .

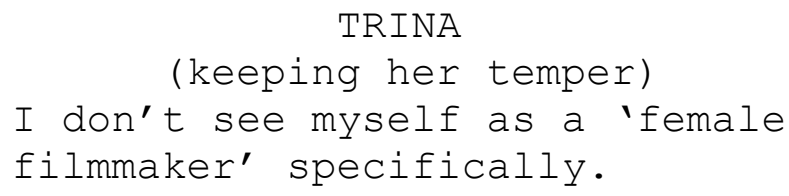

\section{JENNA}

Okay, but you might consider yourself an inspiration for young women wanting to make films.

TRINA

Of course. 
JENNA

What would your advice be to them?

TRINA

To work hard and get on with it.

I've never asked for special

treatment and I think that's why

I've earned the respect I have.

TITTERS. GROANS .

JENNA

Now, you have two adorable

children...

TRINA

(softens)

Yes, I do.

And there they are, replacing her image on the screen behind.

JENNA

...so the big question is, with all

that you've got going on, how do

you balance work and family?

HOOTS OF RECOGNITION.

TRINA

Well, I'm lucky to get a lot of support, but in a sense I'm just like any other working mother.

MORE LAUGHS .

JENNA

And, of course, that's what your award winning film is all about.

TRINA

Exactly. And it was a chance to create roles for women other than someone's wife.

MORE LAUGHS .

TRINA absent-mindedly winds at the ring on her wedding finger.

JENNA

Do you consider the film a womanist

story?

FRESH WAVES OF LAUGHTER. 
TRINA

(bristles)

Not necessarily.

Reveal -

2. INT. INDEPENDENT CINEMA - NIGHT

- where an audience of mostly men watch this unfold on the big screen.

JENNA

So you wouldn't call yourself a womanist?

TRINA

No, I mean - well, I believe we're

all equal so, well, no... I don't

think we need those sorts of

labels.

The audience is united in more laughter and groans of recognition.

No one's laughing harder than ANDY LEDERMAN, watching proudly from the side of the screen.

After a moment, he acknowledges the camera, documentary-style, with a thumbs-up.

TITLE UP: MOUNTING THE MEN'S FILM FESTIVAL

Meanwhile, onscreen, things are falling apart.

$$
\begin{gathered}
\text { TRINA (CONT'D) } \\
\text { (standing up to leave) } \\
\text { Seriously, Jenna? } \\
\text { JENNA } \\
\text { Hey, I don't write the questions. }
\end{gathered}
$$

As TRINA tries to storm out, CREW and equipment are revealed as obstacles in her path.

TRINA

Where's my publicist? 
A light stand comes crashing down as she clocks the image of a Hollywood hunk on the screen behind her.

ANDY laughs extra hard. Then checks to see if others near him are finding it as funny.

TITLE UP: POWER CUT

A glimpse of ANDY's t-shirt reveals a MELBOURNE MEN'S FILM EEST logo.

A punter reads an insert in their program: DON'T BE MIFFED, JOIN MIET - MEN IN FILM \& TELEVISION!

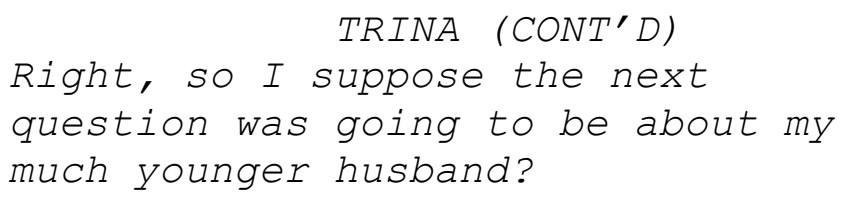

Throwing her notes in frustration...

JENNA

(snide)

Well, the whole world's wondering

how you did it!

As the screening draws to a close, festival VOLUNTEERS (MEN) whisper into handsets.

Other struggle to keep a wonky merch table upright. Despite their efforts, piles of t-shirts start sliding. A MMFF mug rolls to the floor, branded with \#AskHimMore.

AUDIENCE MEMBERS fan themselves with programs. A few are taking notes.

Two in-house venue techs (AMY and JULES), obliged to be there, are bemused by the proceedings.

TRINA
(Ieaving)
I'm terrific at blowjobs!

More laughter as the onscreen story cuts to a new scene - but soon the audio cuts out, and the visual is replaced with the MMFF logo.

As the cinema lights come up, ANDY's on the mic.

\section{ANDY}

A big round of applause for our special festival guest, Marty Madden! 
Find MARTY, sitting in a side front row, smiling modestly.

Then mouthing a self-conscious 'hello' to camera.

As the clapping and cheering subsides...

\author{
ANDY (CONT'D) \\ For those who don't know me, I'm \\ Andy Lederman, Festival Director...
}

One VOLUNTEER attempts to start a fresh round of applause but, caught on camera, quickly backs off.

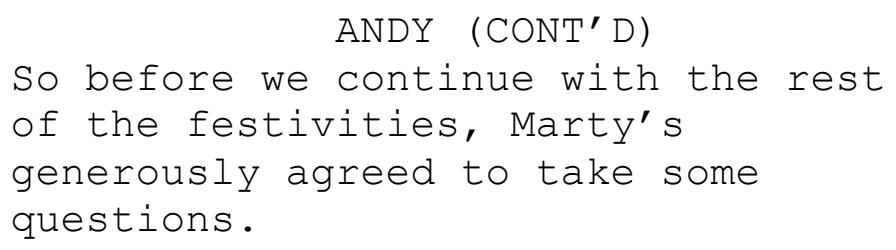

As MARTY joins ANDY at the mic, AMY and JULES are joined by some more FEMALE VENUE TECHS. They chat inaudibly, banded together, occasionally shuffling their feet, or looking around to check out the punters. One strokes distractedly at the two-way radio on her hip.

CUT TO:

\title{
3. INT. MMFF OFFICE - EARLIER
}

Looking off camera to an unseen interviewer, ANDY's excited about the big night ahead.

\section{ANDY}

Tonight's opening event is all

about celebrating men's voices, and

men's stories onscreen.

Behind him, a group of his VOLUNTEERS (MEN) are huddled around a computer monitor, laughing at a classic comedy routine involving two women moving a piano up the stairs.

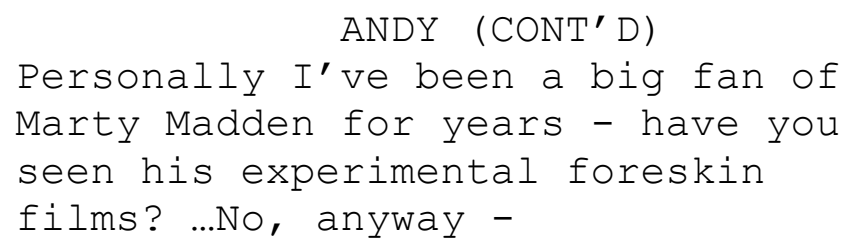

As ANDY talks, the camera picks up cutaway.

VOLUNTEERS (MEN) taking phone calls.

Making copies. 
Some are amusing the children they've brought with them to the office.

One is desperately trying to add the missing apostrophe to a MELBOURNE MENS FILM FESTIVAL banner.

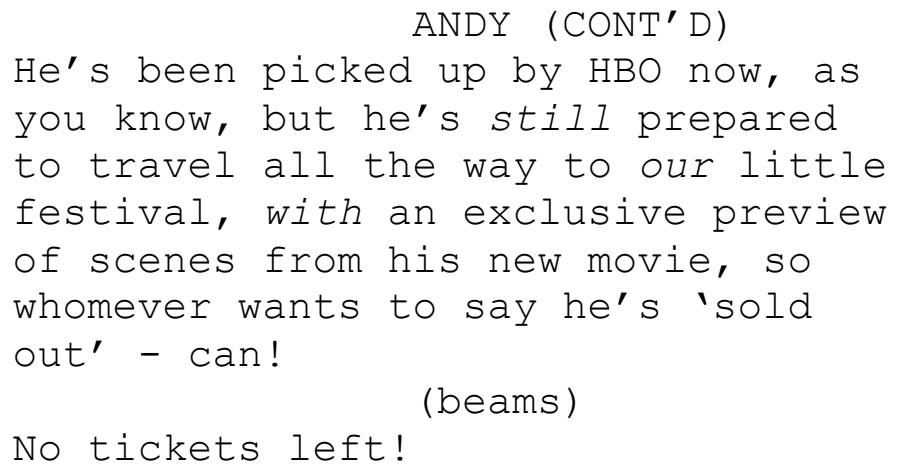

An unattended CHILD (GIRL) draws boobs on a man's picture in the festival program.

CUT TO:

\section{INT INDEPENDENT CINEMA - NIGHT}

MARTY's Q\&A continues.

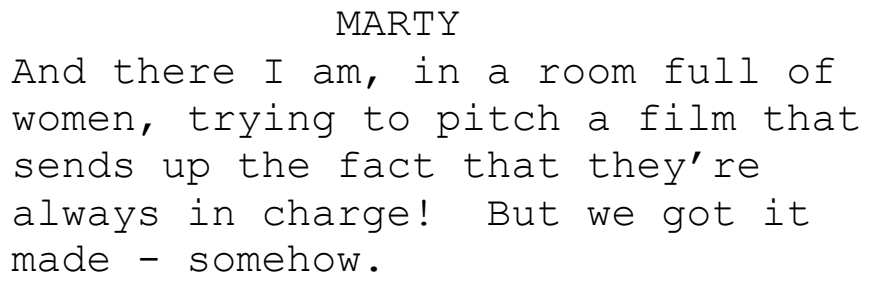

Friendly laughter - but the previous QUESTION ASKER is still holding the audience mic.

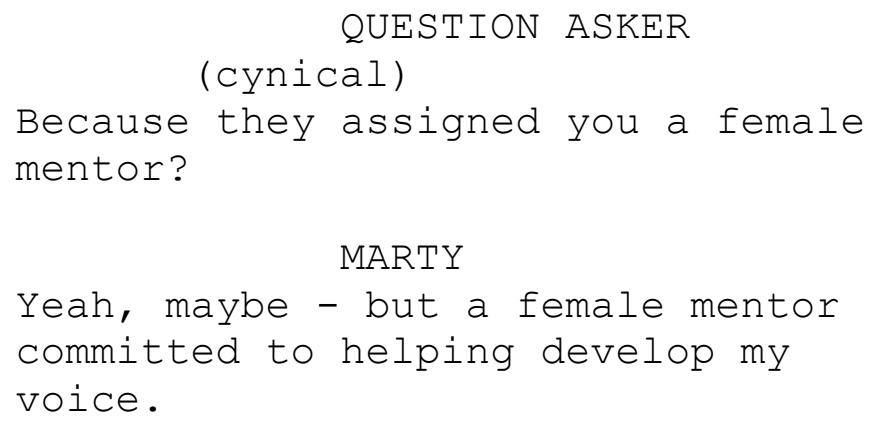

A WOMAN, one of the few in the audience, sits more upright in her seat. 


\author{
ANDY \\ (hasty) \\ Another question? Okay, yes, you \\ on the right...
}

A VOLUNTEER awkwardly runs the mic to someone else.

QUESTION ASKER 2

Thanks Marty, um, just wanted to

ask how much is drawn from your own

life?

MARTY

Look, none of those characters are

me; but of course the script was a

place to channel my own

frustrations - like why the media

make such a big deal out of me

dating a younger woman!

Spontaneous applause.

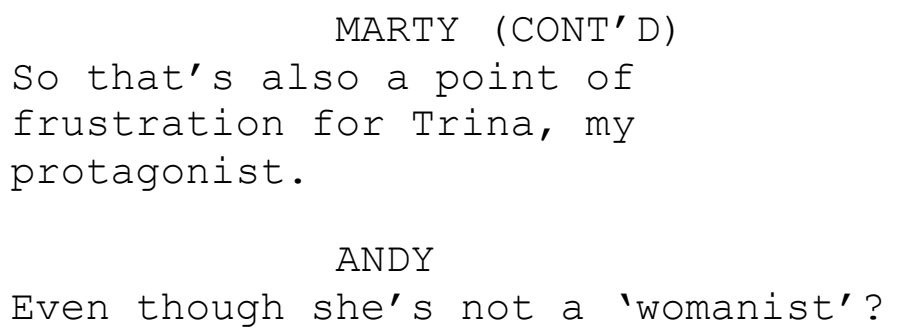

He flicks his eyes quickly to the audience, happy to be rewarded with their laughter.

\title{
MARTY
}

That's right.

(beat)

I still think there could be a better word for that...

A new QUESTION ASKER has procured the mic.

QUESTION ASKER 3

Is Trina based on Troy Miller?

Laughs of recognition. MARTY laughs too, shaking his head noncommittally -

CUT TO: 
5. INT PERSONAL STUDY - DAY

TROY MILLAR sits at his desk, talking to an unseen

interviewer.

Awards are displayed behind him.

A framed cover of Good Housekeeping magazine screams TROY MILLAR - MAN OF THE YEAR.

\section{TROY}

Look, I declined to attend that

little Men's Film Festival because

I don't want to be limited by my

gender. You know what, I'm not

even that comfortable in the

company of other men.

(proud)

I like to think of myself as just

one of the girls. Y'know? They

have each other's backs.

CUT TO:

6. INT INDEPENDENT CINEMA - NIGHT

VOLUNTEERS (MEN) are pouring cask wine into glasses in the foyer.

One surreptitiously pours some into his \#AskHimMore mug.

In the theatre -

\section{ANDY}

Now after the break don't forget

our world premiere of 'stud

Shaming' by Justin Harris!

Find JUSTIN in the crowd, among a few friends giving supportive whoops.

$$
\begin{aligned}
& \text { ANDY (CONT'D) } \\
& \text { So, while we get that set up... }
\end{aligned}
$$

A VOLUNTEER at the back looks blank. Then indicates to ANDY that he's on it.

...I think we have time for one more

question. 
The big screen displays a computer desktop, magnifying the awkward machinations involved in getting the digital file up for stud Shaming.

The VOLUNTEER runs the mic to QUESTION ASKER 4, almost tripping in their haste for a smooth transition.

$$
\text { QUESTION ASKER } 4
$$

I know we were only able to see a few scenes, but there didn't seem to be any men in the cast.

Another of the few WOMEN, there with her MALE PARTNER, rolls her eyes. So does he.

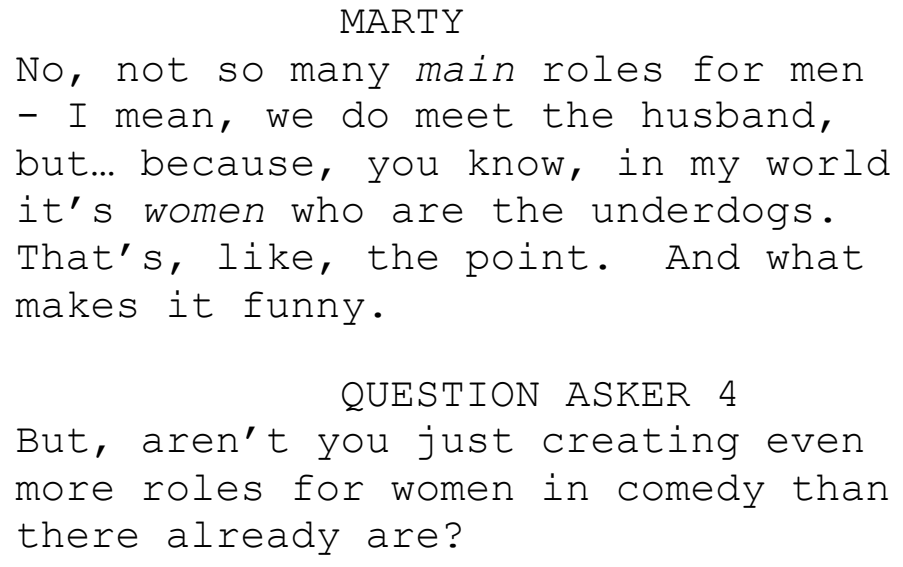

Pause.

MARTY searches for a response.

ANDY waits.

The MALE VOLUNTEERS wait.

The MALE PUNTERS wait.

Eventually...

\section{MARTY}

Well, without wanting to give too

much away, there are some pretty

funny cameo roles for men...

The power goes out.

There's a collective gasp before the dim emergency backup lights come up and the VENUE TECHS (WOMEN) kick into gear, ushering VOLUNTEERS (MEN) aside.

OVER CLOSING CREDITS: 
ANDY looks in despair at the black screen, while MARTY taps on the dead mic. The VENUE TECHS have formed a chorus of laddererecting, torch-shining, ceiling-pointing, technicalgibberish-spouting saviours.

AMY

Yeh, I reckon the amp blew out the transponder.

\section{JULES}

Nah, mate, too much juice in the sub-woofers...

ANDY tries to interrupt.

ANDY

Isn't it just a fuse?

AMY

Okay, love; has anyone ever

explained to you the concept of

three-phase power?

Another FEMALE VENUE TECH approaches.

FEMALE VENUE TECH

(accusing)

Was everything tagged?

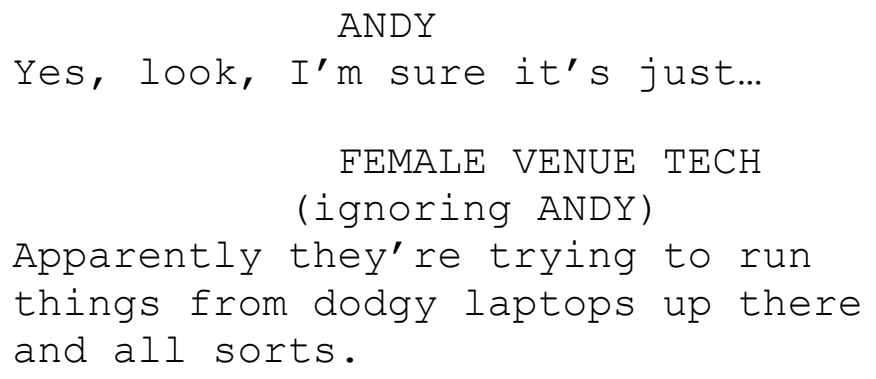

JUSTIN approaches ANDY.

JUSTIN

What's happening? What about my screening?

AMY

(to ANDY)

If you could just get your people

to file out and leave it to us...

General confusion and battle of wills as - 
OVER BLACK :

JULES

I don't know why they need their own festival anyway. Men are everywhere these days.

AMY

I know. Where's the women's film

festival? I'd like to see that...

END OF SCRIPT 


\section{Research statement}

\section{Research background}

The script reflects the author's current $\mathrm{PhD}$ research on developing comic screenplays. It draws from scholarship relating to comedy - particularly its reliance on perspective (Horton 1991) and deviance from what is considered the norm (King 2002, Mills 2005). While 'gender switch' may succeed in exploiting perspective - creating new norms from which to depart - it might also reinforce the same binaries it sets out to challenge. The script is a creative expression of those concerns, and a response to scholarship on screenwriting practice and gender (see, Jacey 2010).

\section{Research contribution}

The script is situated within a growing scholarly field of screenwriting practice, as well as wider bodies of work on gender in comedy and on screen. A creative articulation of questions around essentialism and subjectivities addressed by Moi (2001) and others, it offers new ways of thinking about gender hierarchies in comedy (Mizejewski 2014). At the same time, it expresses a gendered critique of dominant screenwriting models, reversing the arguably default (male) perspective inherent in those structures (Dancyger and Rush 2007, Mulvey 1975).

\section{Research significance}

This original work is unique in offering a multi-layered, scholarly informed approach to the 'gender switch'. The world of the webisode reverses gender hierarchies, while also reflecting our own world back at us, double flipping the binaries it seeks to critique. It creatively answers the questions raised within its own text, deliberately employing 'otherising' as a narrative device, while also questioning its effectiveness. As a critique of dominant screenwriting models, the gender switch device is tested through practice. The device risks reinforcing those models' generic, hyperindividuated protagonists - especially those specific to comedy whereby the comic outsider is more easily negotiated as masculine (Mizejewski 2014) while still emphasising arguments around gendered, comic perspectives.

\section{Works cited}

Dancyger, K \& Rush, J 2007 Alternative scriptwriting: successfully breaking the rules 4th ed Focal, Burlington, MA

Horton, A 1991 Comedy/Cinema/Theory U of California P, Berkeley and Los Angeles

Jacey, H 2010 The woman in thesStory: writing memorable female characters Michael Weise Productions, Studio City, CA

King G 2002 Film comedy Wallflower, London

Mills B 2005 Television Sitcom British Film Institute, London

Mizejewski L 2014 Pretty/Funny U of Texas P, Austin

Moi, T 2001 What is a woman?: and other essays Oxford UP, Oxford 
Mulvey, L 1979 'Visual pleasure and narrative cinema', in EA Kaplan (ed) Feminism and film Oxford UP, New York 


\title{
York University, Toronto, Canada
}

\section{Temenuga Trifonova}

\section{Man of glass}

\begin{abstract}
:
Man of glass is a script about delusion and obsession, sanity and insanity, and the line between the two. The story unfolds against the backdrop of fin de siècle Paris, a turbulent period marked by the rise of the new 'sciences of mind' - psychology and psychiatry and the development of new 'scientific' theories of madness and criminality. Disgusted with the mercantilism and vulgarity of the bourgeoisie, Gaspard de Ronsard, a decadent, neurotic aristocrat, impulsively assumes the identity of a stranger, who might be the serial killer that has been terrorizing Paris, only to find out that someone else has assumed his own identity. Trapped in the position of an impostor, Gaspard struggles to reclaim his identity ... even as it becomes increasingly unclear whether he is not the man he thinks he is pretending to be. The script poses existential questions about the fragility and ambiguity of identity, the possibility or impossibility of escaping who we are, and the dangerous obsession with becoming someone else.
\end{abstract}

\section{Biographical note:}

Temenuga Trifonova is Associate Professor of Cinema and Media Studies at York University, Toronto. She is the author of Warped Minds: Cinema and Psychopathology (Amsterdam University Press, 2014), European Film Theory (Routledge, 2008), The Image in French Philosophy (Rodopi, 2007), and numerous scholarly articles in peerreviewed journals and edited collections. Her first novel, Rewrite, was published in 2014. Temenuga is the recipient of several fellowships and artist residencies, including the Pushkinskaya-10 Center International Artist Residency (St. Petersburg, Russia), The Dora Maar Fellowship (France), the Fondation des Treilles residency (France), and the visiting senior fellowship at the Davis Centre for Russian and Eurasian Studies at Harvard University. Her research and teaching interests include: Film Theory, Film and Philosophy, Screenwriting, Film and Photography, European Cinema, Film and Literature, The Sublime, Medium Specificity, Film Criticism, Film Remakes, Contemporary American Cinema, and Creative Writing (Fiction).

Keywords:

Creative Writing - Paris - Fin de siecle - Psychology 


\section{THE CHARACTERS}

GASPARD DE RONSARD - a decadent Parisian aristocrat, 30, tall and handsome

DOCTOR GIRARD - psychologist, in his 50s, short and stocky, wears glasses

JUDGE - in his 50s, judge in the court of law, tall and authoritative

PROSECUTOR - in his late 40s, tall and skinny, very confident, a bit cocky

ATTORNEY - in his late 40s, soft-spoken, with a childish face DOCTOR DUCHENNE - in his 50s, medium built, with a serious face, a bit lacking in social skills

DOCTOR CHARCOT - in his 50s, gregarious and self-assured

PRISON CHAPLAIN - in his 60s, humble, soft-spoken

GILBERT - in his 30s, tall and handsome, blonde hair

ALBERTINE - in her 20s, in poor health, greasy hair and dirty clothes, but still beautiful

IMPOSTOR - we never see his face but he looks in his early $30 \mathrm{~s}$, tall and lean

CAPTAIN BOILEAU - in his early 50s, stocky and bald, has a striking moustache

CONCIERGE/TAILOR - in his 50s, average looking, medium height, dark hair and dark eyes

HOTEL RECEPTIONIST - in his 40s, very skinny, big eyes, sunken cheeks

YOUNG PROSTITUTE IN THE STREET - 17, very pretty, looks jaded and tired 


\section{SETTING/STAGE DESIGN}

Paris, late $19^{\text {th }}$ century. The action takes place in several major locations: the protagonist's Paris apartment, a café, the house of a prostitute, the courthouse, prison, a hotel, the Salpêtrière hospital, the streets of Paris 


\section{MAN OF GLASS}

\section{TITLE UP: PARIS, 1892}

FADE IN :

INT. PARIS - GASPARD'S APARTMENT - EVENING

The room, large and opulently furnished, is filled with opium smoke. The silhouette of a man slowly takes shape in the midst of the smoke. He is DUKE GASPARD DE RONSARD, 30 years old, handsome. His eyes are glazed over and his forehead is covered with sweat. He is wearing an unbuttoned fine white shirt. Gaspard inhales deeply from his opium pipe and closes his eyes. The expression on his face is orgasmic. Gradually, his face disappears back into the smoke.

OVER THIS IMAGE A LEGEND APPEARS: MAN OF GLASS

CUT TO:

EXT. GASPARD'S APARTMENT - EVENING

Gaspard stands at the window looking out. The heavy curtains are drawn aside. A SCULPTURE sits on the windowsill. TWO WOMEN, half-naked, enter the frame from either side and start caressing and kissing Gaspard. He abandons himself to their caresses without responding to them.

\section{FATHER CHARLES (O.S.)}

I call desolation the darkness of soul, disturbance in it, movement to things low and earthly, the unquiet of different agitations and temptations, without hope, without love, when one finds oneself all lazy, tepid, sad, as if separated from...

CUT TO:

EXT. PARIS - THE SEINE - EVENING

Gaspard walks by the river. The muddy embankment is covered with decomposing leaves and dirt. He bends down and breathes in the wretched smell. A HOMELESS MAN is sleeping on the ground. Lying next to him is a brown bag containing a piece of 
meat covered with MAGGOTS. Gaspard bends down and watches the maggots' incessant movements.

CUT TO:

EXT. PARIS BANLIEUE - STREETS - EVENING

Gaspard wanders down the street. He is now is one of the poorest parts of the city. A rat runs between his feet. A child is CRYING in one of the houses he passes by. He stops in front of the house. A young prostitute, badly made-up, is leaning against the wall. She raises her skirt above her bony, dirty knees. She is ALBERTINE.

CUT TO:

INT. PARIS BANLIEUE - ALBERTINE'S HOUSE - EVENING

Gaspard stands in the middle of a dimly lit, cheaply furnished room. He can still hear a child CRYING somewhere in the house, though now the crying is more subdued. Albertine walks toward him, awkwardly caressing her pale, transparent skin and smiling wearily. She lets her long hair down: it looks like it hasn't been washed for a while. Her face is expressionless and she looks malnourished. Her chest is flat. She motions to him to come closer. He does. She starts undressing him. Gaspard pushes her on the bed and lies on top of her. He lifts up her dress and starts caressing her thin legs. She lies there obediently without moving. He continues sliding his hand over her leg mechanically, as if he were rubbing an object.

Suddenly he feels the girl's hand on his crotch. She tries to smile seductively and puts his hand on her non-existent breasts. He doesn't respond. She tries to kiss him. He doesn't respond. All of a sudden, he pushes her away, gets up and picks up his coat. Albertine extends her bony arm, trying to pull him back.

\section{ALBERTINE}

Does Monsieur have any special requests?

Gaspard pulls away and leaves.

CUT TO:

EXT. MADAME BUFFET'S BROTHEL - EVENING

Gaspard stops in front of a big house. The door opens and MADAME BUFFET, a middle-aged woman with a big mouth and a deep cleavage, comes out, surrounded by young prostitutes, all provocatively dressed. She extends her arms to Gaspard. 


\section{MADAME BUFFET}

Welcome to the House of Pleasure!

INT. MADAME BUFFET'S BROTHEL

Gaspard is half-sitting, half-lying on a sofa in the middle of the room, smoking opium. Several half-naked girls are lying on top or next to him, their arms and legs wrapped around his body. Through the smoke he sees a YOUNG MAN, modestly dressed, sitting on the smaller sofa in the corner. Standing by the young man is Madame Buffet, gesticulating profusely and pointing to the few coins in his hand. She grabs the coins from his hand and throws them on the floor.

INT. PARIS CAFE - EVENING

CLOSE ON the absinthe inside a glass. Gaspard shakes the glass and brings it up to his mouth. PULL BACK to reveal: Gaspard and GILBERT, another aristocrat, are playing baccarat. Gaspard is absent-mindedly drawing a nude on a napkin, not paying attention to the game.

\section{GILBERT}

Where did he tell you he worked?

GASPARD

Laurent \& Moreau. An accounting firm.

\section{GILBERT}

You paid an accountant 500 francs?

GASPARD

I paid Madame Buffet. She runs the brothel.

Gaspard lights a cigarette.

\section{GASPARD (cont.)}

I am simply trying to train a murderer.

Gilbert looks confused. Gaspard leans back, cigarette in hand.

$$
\begin{gathered}
\text { GASPARD } \\
\text { (lethargic) }
\end{gathered}
$$

The boy's a virgin. He could've run after the little girls of his neighbourhood, amusing himself but remaining decent, content with his little share of the tedious joy reserved for the poor. I want the thought of a regular life, working in an office for his daily bread, to start to oppress him. I want him to get accustomed 
to carnal pleasures he cannot afford to enjoy. I expect it will take a month for these pleasures to become indispensible to him. At the end of the month, I'll cut off the little allowance I gave Madame Buffet. And then...

Gaspard pauses dramatically.

GASPARD (cont.)

The boy will go to any lengths: steal, even kill, to roll on that sofa again.

Gaspard starts dealing the cards. Gilbert interrupts him.

\section{GILBERT}

No, no, you have to deal the third card face up...

Gaspard drops the cards on the table.

GASPARD

I am not in the mood.

Gaspard looks around contemptuously. The café is crowded.

\section{GASPARD}

This city is done for. The bourgeois are lording it over everyone, counting their money, eating out of picnic paper bags.

Across the street TWO BOYS, around 10, are fighting fiercely, rolling on the ground, sand in their hair and snot under their noses. Gaspard observes them with disgust.

GASPARD

Look at these brats!

Gilbert looks at the boys.

\section{GASPARD (cont.)}

They would have been better off not being born. What do they have to look forward to except measles and slaps, kicks and meaningless chores, the cunningness and deceitfulness of women and, towards the end, infirmity and death in a poorhouse or an asylum! 
One of the boys, trampled to the ground, starts crying while the other one continues kicking him and throwing stones at him.

$$
\text { GASPARD (cont.) }
$$

To be fair, it's the same for everyone.

With the rich it's the same pains and the

same mediocre pleasures-alcoholic,

literary or carnal.

A WAITER approaches them, carrying a tray covered with food. Gaspard's face twists in disgust.

\section{GASPARD \\ Throw this to those brats murdering each other!}

The waiter walks over to the boys. They start fighting over the food.

CUT TO:

EXT. PARIS STREETS - EVENING

CLOSE ON Gaspard as he staggers down the street, overwhelmed by the city noises: horses neighing, drunken screams, women's vulgar laughter, street vendors' cries. He recoils from the people around him: close ups exaggerate their ugly, twisted faces. Gaspard leans against a building, turns towards the wall and vomits.

\section{PROSTITUTE (O.S.) \\ (apathetic) \\ Looking for love, Monsieur?}

Out of the shadows emerges a VERY YOUNG PROSTITUTE with a worn out face. She is practically a child. He takes a few steps back, away from the girl, who continues staring at him. He puts up his collar, turns around and trudges through the mud. A NEWSPAPER BOY runs in front of him, nearly pushing him over.

\section{NEWSPAPER BOY}

Le Figaro! Le Figaro! Read the latest

crime stories! The Phantom Killer strikes again!

CUT TO:

\section{EXT. GASPARD'S APARTMENT - NIGHT}

Gaspard stumbles down the street. Breathing with difficulty, he takes out a cigarette; his hands are shaking. He searches his pockets for a light but can't find any. Without looking 
around him, he wanders into a building right across from his apartment building: Hotel L'Etoile.

CUT TO:

INT. HOTEL L'ETOILE LOBBY - NIGHT

The RECEPTIONIST, a very old man, is reading a newspaper article titled "Who Is the Phantom Killer?" Gaspard approaches the counter unsteadily.

Do you have a light?

The receptionist looks up from the paper and smiles pleasantly. He offers Gaspard a light and places a hotel key on the counter.

\section{RECEPTIONIST \\ Breakfast at 10 o' Clock as usual?}

Gaspard stares at the key.

$$
\begin{gathered}
\text { GASPARD } \\
\text { (as if in a trance) }
\end{gathered}
$$

As usual.

He picks up the key and heads for the stairs. He checks the number on the hotel key: room 12.

CUT TO:

INT. HOTEL L'ETOILE HALLWAY - EVENING/NIGHT

Gaspard walks down the hotel hallway. The walls are covered with faded wallpaper, whose original colour is hard to guess.

CUT TO:

INT. HOTEL L'ETOILE ROOM - NIGHT

Gaspard surveys the room: there are no personal belongings except for a nondescript pair of shoes. Gaspard opens the closet: inside there are two identical suits, of the type an accountant would wear. He sits on the bed and looks around. The only sound in the room is the measured tick-tock of the clock. Time passes.

Gaspard gets up from the bed and walks over to the closet. He starts undressing. He folds up his clothes and puts them at 
the bottom of the closet. He then changes into the hotel guest's suit.

There is a notebook lying on the floor. He picks it up and lies on the bed. The notebook is filled with abbreviations of names, addresses, dates and times. The first entry reads "corner of Rue du Port and Rue de la Capitale, July 17, 8 o'clock in the evening." Gaspard lets the notebook fall flat on his chest and falls asleep immediately.

CUT TO:

EXT. CORNER OF RUE DU PORT AND RUE DE LA CAPITALE - NIGHT

Gaspard walks up and down the deserted street. He is dressed in the clothes he found in the hotel room. Suddenly, there is a GUN SHOT followed by a SCREAM. Gaspard runs around the corner. He catches a glimpse of a MAN running around the corner at the opposite end of the street. Somewhere a window is SHUT closed. Gaspard turns around: in a little dark alley ANOTHER MAN slumps to the ground.

Gaspard approaches the dead body. The dead man is dressed modestly, like an accountant. Gaspard searches his pockets and finds identification papers. He inspects them closely.

$$
\begin{gathered}
\text { GASPARD } \\
\text { (reading) } \\
\text { 'Theodore Blanc'. }
\end{gathered}
$$

Gaspard bends over the body and picks up a REVOLVER lying next to it. A policeman comes running: he is CAPTAIN BOILEAU.

BOILEAU

$$
\text { (to Gaspard) }
$$

Name?

GASPARD

(hesitates)

Camus. Francois Camus.

\section{BOILEAU}

What did you see?

Gaspard extends his hand, holding the revolver, and looks Boileau straight in the eyes.

\section{GASPARD}

No one saw me. 
INT. PARIS - ASSIZE COURT - DAY

The court is almost empty except for A FEW MEN AND WOMEN of the Paris high society. The JUDGE, a man in his 60s, with a weary face, sits behind a massive desk. The PROSECUTOR, a middle aged man with sharp, piercing eyes, walks back and forth in front of the judge, occasionally pointing at Gaspard, who sits in the front, guarded by Captain Boileau.

\author{
PROSECUTOR \\ Your Honour, the defendant is Francois \\ Camus, age 30, occupation unknown, \\ residence unknown. On the night of July \\ 17, the defendant attacked and murdered...
}

The prosecutor ruffles through his papers, looking for the victim's name.

PROSECUTOR (cont.)

... Theodore Blanc. The bullet that killed

Blanc matches the revolver the defendant

was carrying at the time he was

apprehended. [Beat] Your Honour would be

interested to know that the bullets that

killed the Phantom Killer's last two

victims came from the same revolver.

CRIES of excitement in court.

\title{
PROSECUTOR (cont.)
}

Doctor Girard will now present his medicolegal report.

DOCTOR GIRARD, an unpleasant man with a disproportionately small head, takes his place in the witness box.

\section{DOCTOR GIRARD}

Your Honour, I found the defendant to be a vain, idle man of a brooding temper, given over to unwholesome introspection, exhibiting strong flat affect, possibly a reaction to the crime he committed. During the initial interrogation he alternated between a calm, rational state and an irritable, narcissistic one. He answered my questions with a subtle but unmistakable whiff of superiority. When I told him the lack of witnesses might work 
in his favour he anxiously claimed full responsibility for the crime. Indeed, he seemed almost desperate at the prospect of being found non-guilty!

Girard wipes his forehead with a handkerchief.

$$
\text { DOCTOR GIRARD (cont.) }
$$

There is no doubt in my mind that Francois

Camus is intellectually capable of perceiving the difference between right and wrong. There is no evidence of a disequilibrium of his mental faculties. I trust no further comment is necessary to establish the defendant's high degree of moral imbecility.

Girard goes back to his seat. The prosecutor stands up again. He addresses the judge.

\section{PROSECUTOR}

Your Honour, born criminals represent a throwback to an earlier stage of primitive human development. There is no other way to account for the defendant's appalling moral insensibility, in which he seems to take a perverse pleasure. There is only one 'treatment' for men of his kind: the guillotine!

The prosecutor returns to his seat. Gaspard leans over.

$$
\text { GASPARD }
$$

(mocking)

Impressive: succinct and eloquent.

The prosecutor is shocked by the unexpected praise. Gaspard's ATTORNEY stands up.

\section{ATTORNEY}

Your Honour, the prosecution is desperately trying to convince us that individual moral responsibility is irrelevant. If offenders were predestined to a life of crime, it would be meaningless to speak of punishment. Gentlemen, the social milieu is the mother culture of criminality; the criminal is just a microbe, which gains significance only by virtue of finding the broth that makes it ferment. 
Gaspard yawns. The attorney is embarrassed by his client's indifference but tries to compose himself.

$$
\text { ATTORNEY (cont.) }
$$

The defendant committed this crime under

the influence of extreme cerebral

excitement. His reason was temporarily

affected by the action of acute mental

distress on a highly sensitive

temperament. [he points to Gaspard]

Francois Camus belongs in a mental asylum.

Prolonged stir in court. Someone in the back opens a bottle of champagne. The judge brings his fist down.

\section{JUDGE}

Silence! May I remind you that the court is not a theatre! The popping of champagne corks is incompatible with the sobriety of a legal proceeding. (to Gaspard) What is your relationship to the victim?

GASPARD

(blasé)

I never saw him before.

\section{JUDGE}

In other words, you murdered a stranger. Did you plan to rob him?

GASPARD

Certainly not!

JUDGE

Were you seeking revenge?

GASPARD

That's one way of looking at it.

JUDGE

(impatient)

Monsieur, it is in your interest to enlighten us.

Gaspard looks out the window as if he is really thinking about the question. He looks back at the judge.

GASPARD

His sartorial taste offended me. 
Gaspard sighs and leans back. He looks bored.

$$
\text { JUDGE }
$$

(resentful)

Monsieur, I urge you to take a little more interest in the proceeding. Your own life is at stake.

\section{ATTORNEY}

If I may, your Honour, the defendant has already confessed to the crime, indicating his desire to be sentenced.

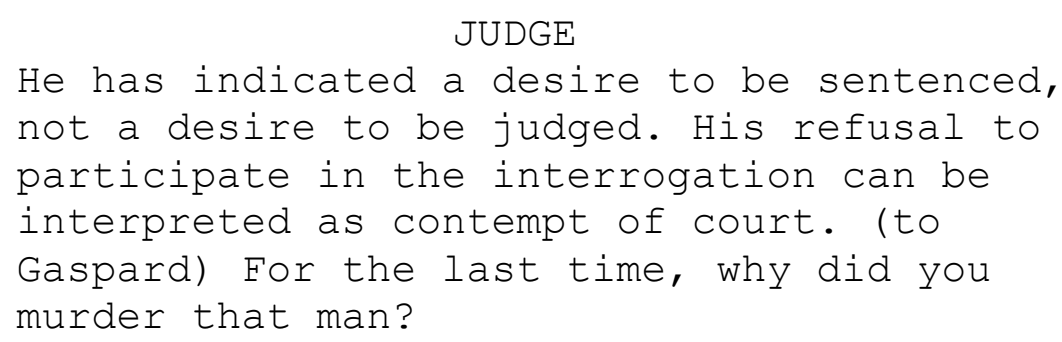

Gaspard looks at the judge calmly.

GASPARD

I wanted to experience the sensations of an assassin in order to analyse them.

The judge exchanges looks with the attorney. The attorney makes a gesture as if to say that Gaspard's insanity has just been confirmed.

$$
\begin{gathered}
\text { JUDGE } \\
\text { (to Gaspard) }
\end{gathered}
$$

Is there anything you'd like to say in your defence?

$$
\begin{gathered}
\text { GASPARD } \\
\text { I can't think of anything }
\end{gathered}
$$

Gaspard turns to Captain Boileau and raises his handcuffed hands.

Shall we?

$$
\text { GASPARD }
$$

CUT TO:

INT. PRISON - GASPARD'S CELL - DAY

Gaspard stands at the window, looking through the bars at the small patch of whitish sky. The door opens and Father Charles 
walks in. He takes a few steps forward and stops, remaining at a respectable distance from Gaspard.

\section{FATHER CHARLES}

Son, I am not here to judge you. Only the Lord can do that.

Gaspard turns around and stares at him.

FATHER CHARLES

You have committed a sin. You have taken another man's life.

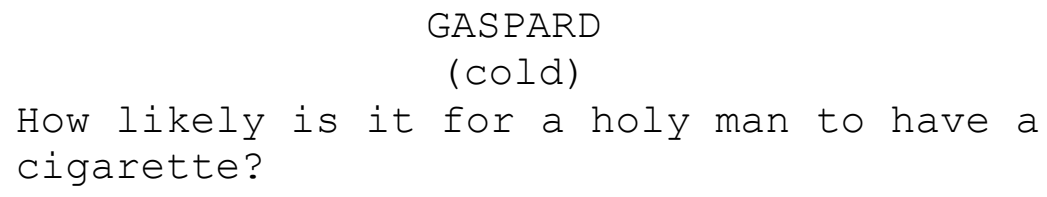

Father Charles smiles sorrowfully and clasps his hands together.

FATHER CHARLES

Do not despair, my son. Let him who is in desolation consider how the Lord has left him in trial in his natural powers, in order to resist the different agitations and temptations of the enemy...

Gaspard starts walking around the cell, looking Father Charles up and down as though he is trying to make up his mind about him. Looking uncomfortable, Father charles tries to ignore him.

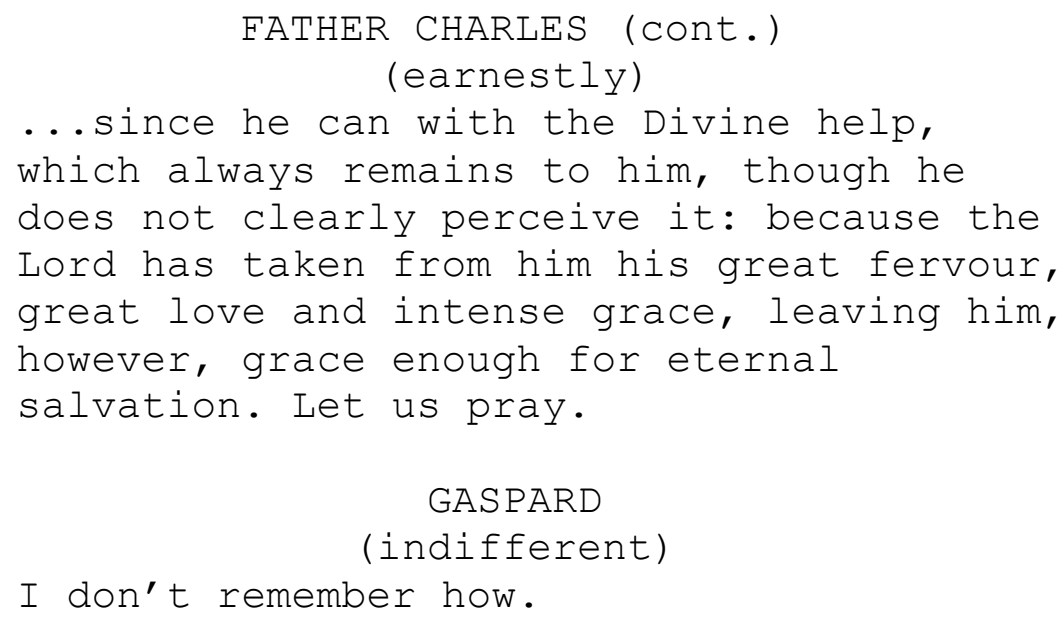

Father Charles approaches Gaspard and puts his hands together.

\section{FATHER CHARLES}


Put your hands together like this. Incline your head forward. Can you not feel your soul invaded by ideas of humility and contrition? Repeat after me: I believe in God, the Father Almighty, Creator of heaven and earth...

Gaspard pulls away from Father Charles, puts his hands in his pockets and resumes walking around the cell.

\section{GASPARD}

Have you looked at a newspaper recently? What do you find on the back pages? Advertisements for corn cures made by priests. The monasteries are now factories producing herbal remedies and liqueurs. The Cistercian order - chocolate. The Dominicans - an anti-apoplectic elixir. The monks of Saint Bruno - Chartreuse. Abbots are turning into confectioners; lay brothers are now pharmacy assistants.

Father Charles doesn't quite know how to respond to this so he continues praying.

\section{FATHER CHARLES}

... and in Jesus Christ, His only Son, our Lord, who was conceived by the Holy Spirit, born of the Virgin Mary, suffered under Pontius Pilate..

Gaspard circles around Father Charles like a vulture. The circles are getting smaller and smaller.

\section{GASPARD}

The ingredients you use for Mass are completely debased. You mix holy oils with chicken fat, candle wax with calcinated bones, incense with cheap resin and old benzoin. You dilute the wine with elderberry, salicylic acid and lead oxide. What about the hosts made of potato starch?! Do you really expect God to manifest himself in potato starch?!

Father Charles is trying hard to remain focused.

FATHER CHARLES

(under his nose) ...was crucified, died, was buried and... 
Gaspard stands face to face with Father Charles.

\author{
GASPARD \\ (matter-of-factly) \\ ...descended into hell.
}

INT. ASSIZE COURT - DAY

CUT TO:

Gaspard, flanked by his attorney and the prosecutor, stands before the judge.

\title{
JUDGE
}

The court has granted you a full pardon.

Gaspard shakes his head and looks at the judge in disbelief.

GASPARD

That's impossible.

JUDGE

We have three witnesses testifying that

you are, in fact, Theodore Blanc,

accountant, residing at Hotel L'Etoile.

Since Monsieur Blanc...since you....are not

dead, we are left with no choice but to

release you immediately. This case is

closed.

Gaspard does not seem at all pleased to be informed of his impending release. The judge stands up.

\section{GASPARD}

(anxiously)

Your Honour, you seem to be forgetting

that you still have a corpse in the

morgue.

JUDGE

You are a free man, Monsieur Blanc. Try to see this as a good thing.

CUT TO:

INT. HOTEL L'ETOILE ROOM - EVENING

Gaspard is sitting at the table. Blanc's notebook lies open in front of him. CLOSE ON the next entry: "rue d'Orsel and rue de Ronsard, August 11, 8 o'clock, evening."

CUT TO: 
EXT. CORNER OF RUE D'ORSEL AND RUE DE RONSARD - EVENING

MONTAGE OF STILL IMAGES:

Gaspard stands in the middle of a deserted street. A GUN SHOT.

Gaspard turns around.

At the opposite end of the street the shadow of a MAN disappears around the corner.

Gaspard bends over a man's dead body.

Gaspard extends his hand, holding a revolver, to Captain Boileau.

CLOSE ON the handcuffs on Gaspard's hands.

INT. ASSIZE COURT - DAY

CUT TO:

The attorney, the judge and the prosecutor are the same as in the first trial. Gaspard sits in the defendant's chair. His face is inscrutable. The judge looks at him for a long time as if he is trying to remember something.

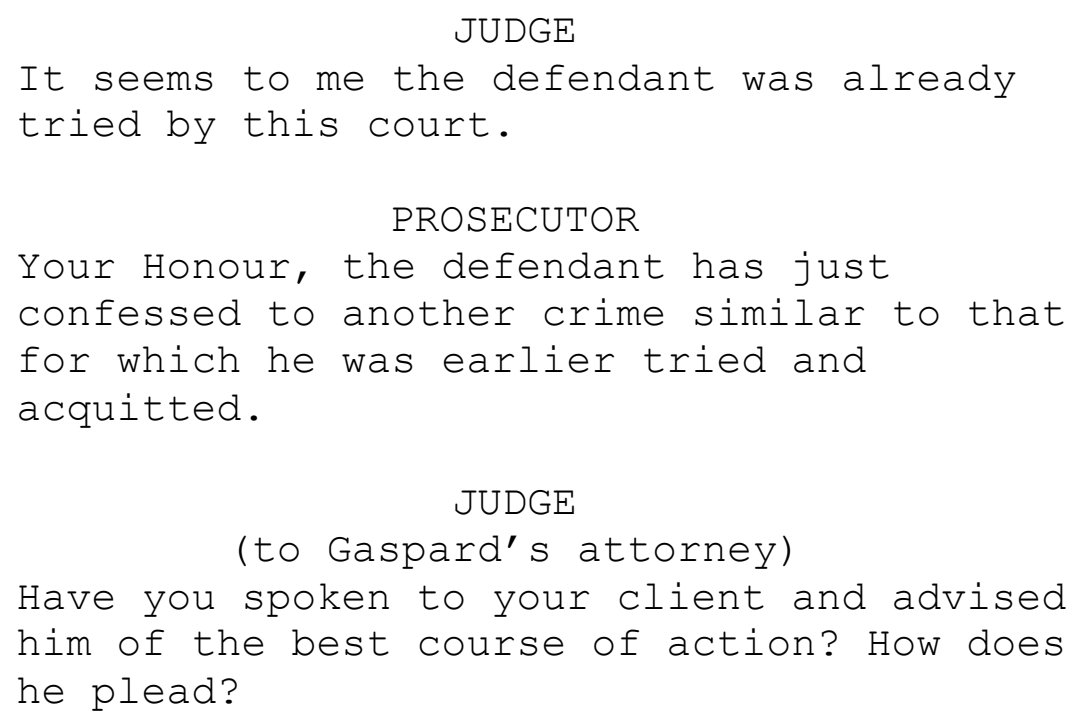

Gaspard's attorney approaches the judge.

\section{ATTORNEY}

My client insists that as his attorney it

is my duty to protect his right to claim responsibility for his own acts and to 
demonstrate that he is as guilty as he claims to be.

\section{PROSECUTOR}

Your Honour, as we saw during the first trial, the defendant is a pathological

liar. I believe his confession is part of an elaborate delusional system of belief, which demands further medical investigation.

The judge appears to have difficulty understanding the rationale behind either man's statement. He waves his wrinkled hand in front of their faces.

\section{Proceed.}

\section{JUDGE}

The attorney returns to his seat. The prosecutor turns around, facing the empty courtroom.

\section{PROSECUTOR}

I call to the stand Doctor Girard. He will demonstrate that the defendant's confession is utterly unfounded and that he is therefore innocent beyond reasonable doubt.

Doctor Girard approaches the stand, carrying a thick bundle of papers, which he proceeds to unroll on the desk in front of the judge. He speaks passionately and gesticulates widely.

\section{DOCTOR GIRARD}

Your Honour, we have recently adopted a new scientific method for eliciting the principal types of insanity by methods of optical superimposition of the portraits of the insane. The composite portrait enables us to obtain with mechanical precision a generalised picture, one that represents no man in particular but portrays an imaginary figure possessing the average features of any given group of men, whether epileptics, hysterics, or what have you. It is mathematically true that deviations from the average man...

$$
\text { JUDGE }
$$

The average man? 
Girard produces a number of photographic portraits of various men. He spreads them out in front of the judge as if he were dealing cards.

DOCTOR GIRARD

The average man is a fictional being with

respect to whom all things happen in

accordance with average results obtained

for society.

Girard picks up ONE of the photographs and holds it up in front of the judge; then he shows it to the attorney and the prosecutor.

$$
\text { DOCTOR GIRARD (cont.) }
$$

This is a composite portrait of hysterical

and delusional patients. The portrait was

obtained from the photographs of all

patients in this class, including the

defendant.

Girard approaches Gaspard and holds the composite portrait next to his face.

$$
\text { DOCTOR GIRARD (cont.) }
$$

You will notice that the portrait bears a

striking resemblance to the defendant.

The judge looks at the portrait and at Gaspard. There is absolutely no resemblance between the two. The judge nods in agreement. Girard produces another set of photographs and spreads them before the judge. He picks ONE of these photographs and holds it up so everyone can see it.

$$
\text { DOCTOR GIRARD (cont.) }
$$

For the sake of comparison, this is a

composite portrait of an average murderer

produced from individual photographs of

all murderers currently serving their

sentence here in Paris.

Girard walks over to Gaspard and holds the composite portrait next to Gaspard's face.

$$
\text { DOCTOR GIRARD (cont.) }
$$

As you can see, the defendant's face

represents a significant deviation from

the composite portrait.

Once again, the judge nods in agreement. 
EXT. THE SEINE - EVENING

Gaspard sits on a bench by the river, staring at the muddy water. He notices an old homeless man standing by the water with his back to Gaspard: the same homeless man he saw earlier. Gaspard observes him for a while.

$$
\text { DOCTOR GIRARD (O.S) (cont.) }
$$

On the basis of the scientific evidence presented here, I believe Theodore Blanc suffers from an unknown kind of mental disturbance, which forces him to claim responsibility for random acts that cannot, in fact, be attributed to him. Since the defendant does not pose an immediate danger to himself or to anyone else, I recommend that the defendant be released immediately.

Gaspard walks over to the homeless man and stands behind him. Beat. Gaspard pushes the man into the river. Everything happens very fast: the man doesn't even scream. Gaspard watches him drown.

CUT TO:

INT. ASSIZE COURT - DAY

The court hearing is under way. The judge takes off his glasses and carefully examines Gaspard's face.

\section{PROSECUTOR}

Your Honour, the defendant is painfully familiar to us: Theodore Blanc, two prior murder convictions, acquitted twice. Last night he was apprehended after allegedly committing another criminal act of the same nature.

$$
\text { JUDGE }
$$

Proceed.

\section{PROSECUTOR}

Monsieur Blanc, please describe what happened on the evening of August 19.

\section{GASPARD}

I was sitting on a bench by the river. I noticed a man. He appeared to be homeless. 
PROSECUTOR

What was he doing?

GASPARD

Nothing. He was staring at the water.

What happened then?

PROSECUTOR

GASPARD

I walked over to him and pushed him into the river.

What was your 'motive'?

GASPARD

He was obstructing my view.

JUDGE

Monsieur Blanc, I'm warning you: you will

be held in contempt of court if you

continue in this manner.

GASPARD

What I said is true.

PROSECUTOR

But is it statistically true?! Your

Honour, I call to the stand Doctor Girard.

Doctor Girard addresses the audience in a calm, self-assured voice.

GIRARD

Your Honour, esteemed members of the jury,

I would like to draw your attention to a

little known fact. Did you know that the

number of letters at the Dead Letter

office in Paris remains stable from one

year to the next?

The judge appears both confused and intrigued by this piece of information.

$$
\text { GIRARD (cont.) }
$$

What does this tell us, you might wonder?

Well, it tells us that every year, all

other things being equal, the same number 
of deaths is registered in Paris. Every year we witness the same crimes, leading to the same penalties, in the same proportions. We can predict the number of murderers, forgers, and prisoners, pretty nearly as we can enumerate in advance the births and deaths that will take place.

Girard is pleased with the effect his words have produced. He looks around triumphantly. As Gaspard listens to Girard's speech, he appears increasingly alarmed.

\section{GIRARD (cont.)}

To understand crime we must examine the laws and customs of society, not the whims of individuals. Individuals are impulsive, irrational, and inconsistent: the truth is, we rarely understand why they do what they do. To think that individuals can serve as the basis of the moral sciences is absurd! The average man, however, we can understand: in the average everything exceptional balances out.

MURMURS in court. Someone applauds but then stops.

$$
\text { GIRARD (cont.) }
$$

The first thing to be established is the defendant's propensity to crime. Supposing men are placed in like circumstances, the propensity for crime is the greater or lesser probability of committing a crime.

As he continues talking, Girard draws diagrams and formulas on a large sheet of paper. Intrigued, the judge leans forward.

\section{GIRARD (cont.)}

After considering a large enough number of cases, I devised an empirical formula, which can be used to calculate the propensity for crime, taking into consideration the specific information available in the defendant's record:

$$
\begin{array}{ll}
Y=(1-\sin X) \frac{1}{1+m} & \text { supposing } m=-1 \\
2 x-18 &
\end{array}
$$

The degree of the propensity for crime $Y$ is expressed as a function of age $X$. It is necessary to take for the axis of the 
abscissas the quarter of the circumference rectified and divided according to decimal division.

Girard holds up the sheet of paper.

GIRARD (cont.)

Using this formula we built a statistical profile for our murderer. We then compared the defendant's profile to the murderer's profile.

The prosecutor produces a sheet of paper containing a statistical table and shows it to the judge.

$$
\text { GIRARD (cont.) }
$$

This table shows the defendant's propensity to crime to be close to 0 . When I took into consideration his education, marital status, age, birth place, time of the crime, place of the crime etc., I concluded that, all his claims to the contrary, the defendant did not, in fact, murder the victim.

Gaspard jumps up.

GASPARD
That my actions are statistically
improbable does not make them unreal!

Captain Boileau forces him back in his seat. Girard produces another document.

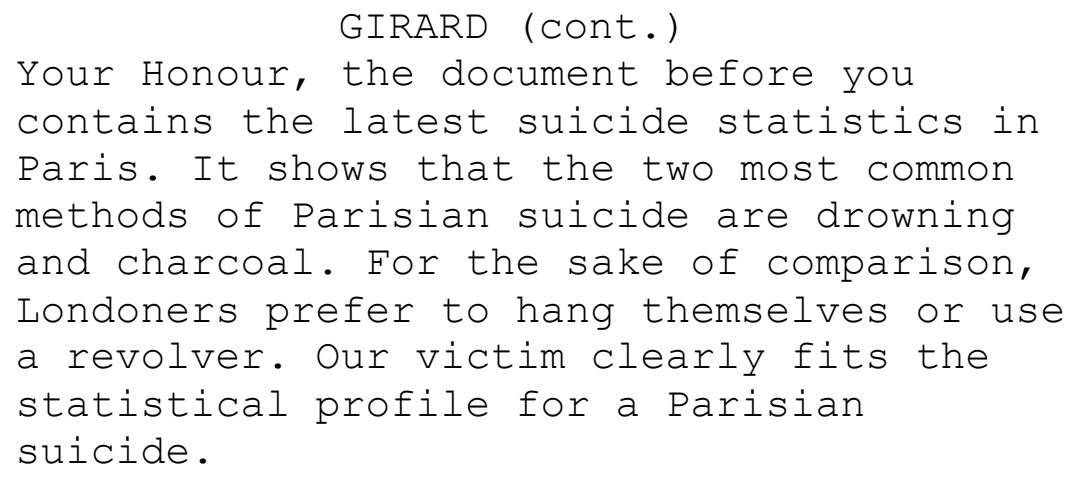

Gaspard tries to stand up again but is pushed back in his seat.

GASPARD

That man did not commit suicide! 
The prosecutor stands up.

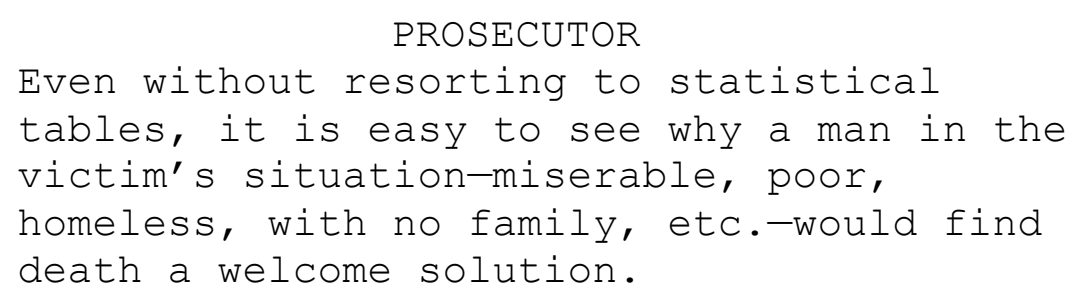

Gaspard makes another unsuccessful attempt to free himself from the captain's clutches.

\section{GIRARD (cont.)}

Your Honour, it is a statistical law that

a certain proportion of the people in

Paris will commit suicide in a given year.

Logically speaking, it is not true of each

Parisian that he or she is free not to

commit suicide. If each person were free

to do so, then it might have happened that

none did so, and hence that would not have

been a statistical law about the

population, which is absurd!

CUT TO:

\section{INT. HOTEL L'ETOILE ROOM - EVENING}

Gaspard stands by the window, staring vacantly at an apartment across the street, the one exactly across from the hotel room. The window is dark.

Suddenly, candle light flickers in the darkness, illuminating a SCULPTURE sitting on the windowsill. Gaspard recognizes the sculpture and freezes: the window across the street is that of his own apartment.

A HAND emerges from the darkness and moves into the candlelight. Gaspard instinctively steps back from the window. A MAN crosses the room: he is wearing Gaspard's clothes. The man's face remains invisible.

CUT TO:

EXT. GASSPARD'S APARTMENT - EVENING

Gaspard watches the entrance to his apartment building. The man living in his apartment-the impostor-comes out of the building and walks down the street. Still unable to see the impostor's face, Gaspard follows him discreetly. 
CUT TO:

EXT. PARIS STREETS - EVENING

Gaspard follows the Impostor at a safe distance.

EXT. PARIS CAFE - EVENING

CUT TO:

The impostor goes into the same cafe where Gaspard played cards with Gilbert earlier. Gaspard looks through the window.

INT. PARIS CAFE - EVENING

CUT TO:

Gilbert and the impostor are sitting at a table, playing cards and drinking. The impostor's face remains invisible.

CUT TO:

INT. PARIS CAFE - EVENING

The impostor gets up from the table and leaves the café, nodding 'hello' to a couple of men sitting at another table.

CUT TO:

EXT. PARIS STREETS - EVENING

Gaspard follows the impostor until he turns around a corner.

CUT TO:

EXT. MADAME BUFFET'S BROTHEL - EVENING

Gaspard walks back and forth before the brothel. Suddenly the door opens and a pretty young prostitute steps out. She takes out a small mirror and fixes her hair and make up. Gaspard approaches her.

$$
\begin{gathered}
\text { GASPARD } \\
\text { Hello Marie. }
\end{gathered}
$$

The girl looks up at him suspiciously.

MARIE

Do I know you?

GASPARD 
Perhaps you know some parts of me better than my face.

Marie looks at him coldly. She is about to say something when the door behind her opens and Madame Buffet appears on the steps.

MADAME BUFFET

What are you doing out here? Come on! He's been asking for you.

Marie runs back into the brothel. Madame Buffet glances at Gaspard indifferently, as if she didn't know who he was. A spurt of laughter erupts from inside the house. Just before Madame Buffet closes the door Gaspard catches a glimpse of a young man, with his back to Gaspard, surrounded by a gaggle of young girls who are passionately caressing and kissing him.

EXT. MADAME BUFFET'S BROTHEL - LATER THAT EVENING

The impostor comes out of the brothel. He kisses indiscriminately the girl flocking around him and throws money at them. When they finally let him go Gaspard follows him at a distance.

EXT. TAILOR'S SHOP - EVENING

Gaspard looks through a window.

INT. TAILOR'S SHOP - EVENING

CUT TO:

Inside the impostor is trying on a tailcoat. The tailor adjusts the tailcoat's collar.

EXT. PARIS STREETS - EVENING

CUT TO:

Gaspard watches the impostor walk away from the camera, then turns around and heads in the opposite direction.

CUT TO:

INT. TAILOR'S SHOP - EVENING

Inside it's dark. The tables are covered with pieces of fabric, coats, shirts and trousers. Gaspard finds the waistcoat the man was wearing earlier. A little piece of paper attached to it reads 'Monsieur Gaspard de Ronsard'. Gaspard tries to put on the coat: he is shocked to find it's too small for him.

CUT TO: 
INT. HOTEL L'ETOILE ROOM - DAY

Gaspard is asleep, slumped in his chair. His dark apartment across the street is suddenly illuminated by a candle. Gaspard stirs in his sleep. One by one he unfolds his limbs and lifts up his head, like a marionette come alive. He looks at the window across the street. The candle goes out. Gaspard stands up and rushes out the door.

CUT TO:

EXT. PARIS STREETS - DAY

Gaspard follows the impostor.

EXT. SALPETRIERE HOSPITAL - DAY

CUT TO:

Gaspard follows the impostor down a street, at the end of which is the salpêtrière hospital. Gaspard stops at a distance from the entrance and watches the impostor exchange a few words with a DOORMAN. The doorman lets him pass. Anxious, Gaspard walks back and forth, unsure how to proceed. The doorman signals to him to approach.

\section{DOORMAN}

How many times do I have to tell you?! The entrance is at the back! You are late again!

Gaspard hesitates for a moment but then walks to the back of the building.

\section{INT. SALPETTRIÈRE HALLWAY - DAY}

CUT TO:

Gaspard looks around. The hallway is empty. A NURSE, dressed all in white, appears seemingly from nowhere. She rushes past Gaspard and throws him a parcel without saying anything. Gaspard opens the parcel: inside is a patient's white robe with the faded initials "TB."

\section{INT. SALPÊTRIÈRE - DAY}

CUT TO:

Gaspard is seated in the centre of a small stage; he is wearing a patient's white robe. Bright lights are hitting his face, nearly blinding him. DOCTOR DUCHENNE, a bald man with long sideburns and unruly eyebrows, approaches Gaspard. 
Gaspard looks past Duchenne, searching the auditorium. A shadowy figure rises from one of the seats in the back and walks toward the exit. Before Gaspard can react Duchenne bends over him, obstructing Gaspard's view of the auditorium, and starts attaching electrodes to his face, stretching his facial muscles in different directions.

\section{DUCHENNE}

I will now produce the expression of glee by stimulating the greater zygomatic muscle with electric current.

Duchenne proceeds to faradize Gaspard's muscles into an expression of glee. Duchenne steps aside. CLOSE ON Gaspard's face: it is stretched in an unnerving, frozen expression of glee.

\section{DUCHENNE (cont.)}

And now I will produce the expression of aggressive malignity by means of electric contractions of the pyramidalis nasi. What is interesting about this subject is that the development of the pyramidal muscle is so full that its isolated contraction under the rheophores gives a dramatic play of cruel instincts, which his will has no power to evoke and which are only latent in his character. I have observed the same phenomenon in a number of subjects, which leads me to the conclusion that the aggressive muscle of malignity is one of those that least obey the will, and that it is put in action only by the instinct or mode of passion of which it is the essential agent of expression.

Duchenne steps aside. CLOSE ON Gaspard's face: it is now stretched out in a terrifying grimace.

\section{DUCHENNE (cont.)}

This expression renders the maximum of hatred and wickedness this subject's pyramidals are capable of expressing. This is all the more peculiar given that he wields extraordinary power over his eyebrow muscles. He can give his eyes varied expressions and move them in contrary directions. But his will does not exert the least action over his pyramidals. He cannot, by any effort, give to his countenance the expression of 
aggression or wickedness. This man is of a very gentle character. Had he fallen prey to evil passions their gymnastic exercise would have very soon developed his pyramidals, changing the habitual expression of his countenance.

APPLAUSE. Duchenne removes the electrodes from Gaspard's face. Gaspard shakes his head and touches his face as if to check it is still there. Duchenne walks off stage. DOCTOR CHARCOT, neurologist and professor of anatomical pathology, in his 60s, comes up on stage.

\section{CHARCOT}

Allow me to draw your attention to a phenomenon Doctor Duchenne has neglected in his experimental work, namely the extent to which subjects can be compelled to commit acts foreign to their natural inclinations in the waking state.

Charcot holds down Gaspard and proceeds to put him in a state of somnambulism by rubbing the top of his head lightly with the palm of his hand and talking to him in a low, soothing voice.

All of a sudden, Gaspard becomes extremely agitated. He paces the stage, gesturing wildly, shooting, stabbing and poisoning imaginary enemies until he finally collapses on the floor. Charcot bends over him and talks to him in the same soothing voice. In a few moments Gaspard comes to his senses and gets up.

\section{CHARCOT}

Gentlemen, although you can't see it, this room is littered with corpses!

Unnerved, Gaspard looks around him. APPLAUSE echoes throughout the auditorium.

CUT TO:

INT. HOTEL L'ETOILE ROOM - NIGHT

Gaspard lies in bed with his clothes on (Theodore Blanc's clothes). He is sleeping.

INT. HOTEL L"ETOILE LOBBY - NIGHT - DREAM SEQUENCE 
Gaspard walks toward the counter in the hotel lobby. The receptionist looks up from his newspaper and smiles pleasantly.

\section{RECEPTIONIST \\ Breakfast at 10 o'clock, as usual?}

CLOSE ON the sculpture of two hands touching on the windowsill in Gaspard's apartment.

The camera pulls back to a CLOSE ON a pair of HANDS in WHITE GLOVES crossed behind a man's back. The man is not entirely visible but it is clear enough that he is an aristocrat.

The man's POV: Theodore Blanc's hotel room across the street. END OF DREAM SEQUENCE

CUT TO:

INT. HOTEL L'ETOILE ROOM - NIGHT

Gaspard opens his eyes His face is very pale, his eyes feverish. He walks over to the window. His apartment across the street is dark. He walks over to the closet, bends down and rummages through the clothes. He stands up, holding something in his hand: a KEY.

EXT. GASPARD'S APARTMENT - NIGHT

CUT TO:

Gaspard stands in the street. With shaking hands he puts a cigarette in his mouth and searches his pockets for matches, but cannot find any. He drops the unlit cigarette on the ground.

CUT TO:

EXT. GASPARD'S APARTMENT - NIGHT

Gaspard drops the unlit cigarette and crosses the street.

CUT TO:

INT. GASPARD'S APARTMENT BUILDING - LOBBY

The concierge is looking at a pornographic picture. When Gaspard walks in, he hides it under the counter.

$$
\text { CONCIERGE }
$$

Can I help you?

GASPARD 
I am looking for Duke Gaspard De Ronsard.

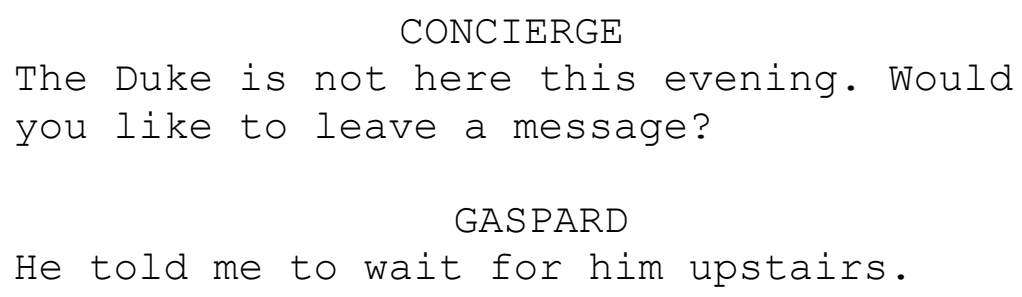

Gaspard smooths down his hair. His hands are slightly shaking. He looks down at them and only now notices he is wearing white gloves. The concierge also looks at the gloves.

\section{GASPARD \\ I am with the firm of Laurent and Moreau.}

The concierge hesitates.

CUT TO:

INT. GASPARD'S APARTMENT - NIGHT

Gaspard takes out the key from his pocket and opens the door. He walks over to the window: the hotel room is visible right across the street. The light in the hotel room is on.

Gaspard stands by the window with his back toward the camera. He opens the desk drawer and takes out something. He puts it down on the desk before him: we cannot see what it is.

The camera pans around the room, stopping briefly on various objects: books by Verlaine and Baudlaire, bottles of perfume, artificial flowers, an opium pipe.

The camera returns to Gaspard, remaining behind him.

CLOSE ON his hands in white gloves crossed behind his back.

Gaspard raises his hands and picks up the object from the desk in front of him.

Pull back and CLOSE ON an elegant waistcoat spread out on the sofa: the same waistcoat the impostor was having tailored earlier. A GUN SHOT echoes through the night. The light in the hotel room across the street goes off.

FADE TO BLACK 


\section{Research Statement}

\section{Research background}

For Freud, 'abnormal' psychic processes are part of 'the normal structure of our psychic apparatus' (1900). For Foucault, too, pathology structures the individual's world in particular ways rather than being a symptom of pre-existing causes (1954). Core to much scholarly discussion of psychopathology is thus the transition from an epistemological to an ontological approach to psychopathology - studying an individual's style of organizing experiencetemporally and spatially rather than studying the content of experience or its causes and effects (Hacking 1995, Fuery 2003) - which I explore in this script and in Warped minds (Trifonova 2014).

\section{Research contribution}

This script contributes to fin de siècle scholarship by drawing attention to photography's role in the development of the new 'sciences of mind', particularly its foreshadowing of the 'discovery' of the unconscious and its importance in the transition from physiognomic to psychological theories of madness. Drawing on numerous cases of ambulatory automatism and double consciousness recorded at the fin de siecle (Azam 1877, Angell 1906) and on theoretical works from the period (Morrison 1843, Esquirol 1845, Londe 1893, Münsterberg 1909), the script undermines the primacy of consciousness, suggesting that consciousness is a secondary state functioning as an inhibitory mechanism disciplining the primary states of unconsciousness, involuntary perception/memory and dream.

\section{Research significance}

This script is one of the first applications of the concept of identity in the $19^{\text {th }}$ century 'sciences of mind', photography and statistics, to a creative work. The work is innovative in that it dramatizes fin de siecle criminological and medical aspects of 'madness' and applies theories of consciousness, photography, and statistics from multiple disciplines to foreground the constructed nature of personal identity.

\section{Works cited}

Angell, EB 1906 'A Case of double consciousness: amnesic type, with fabrication of memory’ The Journal of Abnormal Psychology 1(4), 155-69

Azam, E 1877 Amnésie périodique ou dédoublement de la personnalité Librarie Feret \& Fils, Bourdeux

Esquirol, JED 1845 Mental maladies: a treatise on insanity Hafner, London

Foucault, M 2008 (1954) Mental illness and psychology Uof California P, Oakland

Freud, S 2008 (1900) The interpretation of dreams Oxford UP, Oxford

Fuery, P 2003 Madness and cinema: psychoanalysis, spectatorship and culture Palgrave Macmillan, London Hacking, I 1995 Rewriting the soul: multiple personality and the science of memory Princeton UP, Princeton Londe, A 1893 La photographie médicale, application aux sciences médicales et physiologiques GautierVillars, Paris 
Morrison, A 1843 The physiognomy of mental diseases Longman, London

Münsterberg, H 1909 Psychology and crime T Fisher Unwin, London

Trifonova, T 2014 Warped minds: cinema and psychopathology Amsterdam UP, Amsterdam 


\title{
Sydney University
}

\author{
Linden Wilkinson and Michael Anderson
}

Artistry and academia: adventures on the other side of orthodoxy

\begin{abstract}
:
This script combines stage and television story-telling styles to investigate how we tell and how we receive 'the truth' in different mediums. The script juxtaposes interior monologues, duologues and performance workshop scenarios to convey the plot, which centres on the role of performance as a data-gathering tool for a fictional research project. Unlike in research, character positionality is intended to provoke questions of credibility to illuminate the risks generated worlds of memory and its re-enactment are blurred. The first draft of the script was designed to stimulate discussion on the ethical challenges inherent in performed research within a cash-strapped research environment. The additional content included in this draft reflects both the interest in the issues the script raised and the interest in 'Maxine' particularly. To accentuate the thematic concern of dramatic truth, all the stories in this draft, as opposed to the script's over-arching scenario, are from documentary sources in the public domain or from interviews with others working in different capacities with post-traumatic stress disorder. It is our intention to question the dynamic relationship between authenticity, engagement and story content. Therefore the script deliberately strays from naturalism to test the relationship between believability and mode of story delivery.
\end{abstract}

Biographical note:

Dr Linden Wilkinson recently attained her doctoral degree from the Faculty of Education and Social Work, Sydney University. Her area of academic interest includes cross-cultural performance and the creation of verbatim theatre. She is also a published playwright, an actor and has worked in series television as a writer, script editor and story editor.

Dr Michael Anderson is Professor in the Faculty of Education and Social Work at Sydney University. His research and teaching concentrates on the role of creativity, the arts (particularly drama) and play have on learning. His recent publications explore how aesthetic education and research is changing in the $21^{\text {st }}$ century.

Keywords:

Creative writing - Performance as research - Mixed methods - Orthodoxy 


\section{Artistry and academia: adventures on the other side of orthodoxy}

\section{The Characters}

MAXINE - 20s, a police officer

SUZIE - 20s, a Researcher

TREVOR - 40s, a psychologist

TED - 40s, an academic

WAYNE - 20s, a police officer

JAKE - 20s, a police officer

\section{Setting}

The stage is bare but for a desk, a computer screen and a chair down-stage right. Upstage is a solid wall from one side of the stage to the other. This becomes a screen. In the centre of the screen/wall there is a functional door. This allows the characters to enter and exit the filmed sequences. 


\title{
AN INNER-CITY SUBURB, NOW.
}

\author{
FADE IN:
}

\section{INT. TREVOR'S OFFICE - DAY}

(A performed sequence)

MAXINE and TREVOR enter from different sides of the stage. MAXINE wheels on a chair. She sits centre-stage. TREVOR sits at the desk.

The house lights fade down. A special fades up on MAXINE.

Rumbling of guns; sounds of the First World War, remote.

MAXINE looks to the screen behind her. An image of the Western Front emerges. It features mangled bodies and a large shell hole.

\section{MAXINE}

The first night of the first battle in France, the AIF lost over 5,000 men. These were all battle-ready boys. They were the reinforced Fifth Division; some had survived Gallipoli. Mates. Knew each other the way only dysentery and desire can bond. Know what I mean? Courage, mateship, sacrifice. Had all that. And experience. But not the right experience. Not the right experience, as it turns out. Not the right experience for France. No-one had told them when you're running for your life across a churned-up field of mud, you dive head first into a shell hole. Because that's where the guns are trained. On the shell holes. So if you dive, you get a wound in the foot. Mate! You get a bloody Blighty! But if you jump feet first, you're history. See? Not the right experience .... nothing prepares you for your first night in France. All the first nights. Some road. Headlights. A car wrapped around a tree. Or some kid on fire in a gutter. My great-great-greatuncle, Lyle, was killed at Fromelles. Everybody's favourite. A clown. He used to wear dresses. To shock his mother.

\section{TREVOR}

You're not Lyle, Maxine. You're not a solider. 
TREVOR and MAXINE exchange a glance.

\section{TREVOR}

You wear a uniform but you're not a solider.

\section{MAXINE}

What I'm saying is: That little kid in the gutter was wearing a dress what was left of one.

\section{TREVOR}

I say to people: what we're looking at is examining a spider's web; what you jiggle over here tends to move over there. So you have to walk around the spider's web again and again and again to work out the pattern...how things are connected, to get a sense of it all, without the blame. Oh yes, but ...No, no, no, no, but it happened. Let's look at what happened. Again.

\section{MAXINE}

She reached up, screaming her lungs out; she wanted to be picked up but her fingers her fingers had been burnt off to stubs, skin just falling off her. Skin just hanging off her; I couldn't pick her up. And the fucking ambulance had been sent to Springwood in Queensland! Fuck that! We were in the fucking Blue Mountains!

\section{TREVOR}

And where are you now, Maxine?

\section{MAXINE}

In a balloon, Doc.

The Fromelles projection fades into a coloured tourist image of the Blue Mountains sandstone escarpments and timbered slops. And drifting across the sky are hydrogen balloons, with striped canopies and baskets suspended beneath.

\section{MAXINE}

In a balloon. Drifting high above. Getting it all into perspective.

\section{TREVOR}

Six hundred metres into the air, okay?

Maxine stands. She wheels the chair off-stage and returns. 


\section{TREVOR}

You don't have to go in there.

Maxine hesitates.

\section{MAXINE}

If I'm not a cop, what am I? May as well put a bag over my head.

Stage lights fade. MAXINE exits through the door in the screen. The door is where the camera is positioned.

Screen now projects SUZIE'S workshop/improvisation class.

TREVOR exits.

CUT TO:

\section{INT. SUZIE'S WORKSHOP - DAY}

(A filmed sequence)

MAXINE enters the class and sits in the semi-circle of chairs. Workshop participants are draped comfortably around the semi-circle. The camera is fixed on the two chairs out the front of the GROUP. Two participants, WAYNE and MAXINE, amble towards the chairs.

SUZIE operates the camera, so she is not visible to us.

\section{SUZIE (V/O)}

“Where am I?" Take one. Remember: connect.

WAYNE watches MAXINE; MAXINE watches SUZIE (i.e. the camera).

$$
\text { SUZIE (V/O) }
$$

Imagination is the building block, creativity the reward.

Finally...

\section{WAYNE}

You - ah - you come here often?

MAXINE acts like she's a barista - down with the arm and makes bubbling milk sounds. The GROUP laughs. 


\section{WAYNE}

Fuck, Dickhead! I'll have a latte!

SUZIE walks into frame from behind the camera.

\section{SUZIE}

Thanks, Maxine, our resident clown. Valuable contribution.

Let's...let's keep going...ah ....Jake?

JAKE steps out from the audience. MAXINE reluctantly surrenders her place. JAKE takes it.

SUZIE speaks to camera. MAXINE is behind her.

\section{SUZIE}

Day 3, Opt in/Opt out research study. The "where am I?" exercise, take 2.

SUZIE exits frame, leaving a troubled MAXINE in frame.

Snap to black.

Stage lights fade up.

\section{INT. TED'S OFFICE - DAY}

(A performed sequence with filmed inserts)

TED sits at the desk.

SUZIE enters

\section{SUZIE}

Ted?

Suzie.

\section{SUZIE}

Is this about my $\mathrm{PhD}-$ ? 


\section{TED}

Your research is - It seems - ah - that the Police F - Service - is

becoming - ah - a little sensitive to possible media scrutiny -

SUZIE

Really?

SHE pulls a USB from her bag. The USB is very precious to her.

TED

- and considering what the Defence Force has - (had to put up with).

During the following SUZIE gives the USB to TED. TED inserts it into the screen. SUZIE takes the remote.

\section{SUZIE}

Ted, the narratives I'm getting are incredible. Just incredible. The culture is abhorrent. No wonder my research participants are planning to leave. No wonder. The amount of bullying - harassment - scratch the surface and these people are traumatized.

SUZIE points the remote to the large screen. The projected image is now smaller, contained. She fast-forwards. We see the continuation of the improvisation with WAYNE and JAKE from Scene 2. No sound. JAKE tells a painful story.

TED watches.

\section{TED}

Sometimes, and it's recognized, the current system doesn't help at all.

\section{SUZIE}

Do you know - there's this one story ... I swore I wouldn't use it but....

SUZIE finds the frame. She slows the image to normal. The camera comes in and out of tight close-ups on JAKE, weeping, on WAYNE, on the group - all listening with intense engagement. Even MAXINE is transfixed.

\section{JAKE}

I just stood there watching.....

INTERCUT WITH: 


\section{SUZIE}

He's been part of a group. They all got pissed, picked on a new recruit. Got him pie-faced.

\section{JAKE}

He was on the ground. Guys on top of him. Then one guy - a Sergeant -

SUZIE

Now he's describes how some fucking big-shot shat ...

JAKE

They held his mouth open.

SUZIE

- defecated - in his mouth.

JAKE

And I didn't do -

\section{SUZIE}

Can you believe that?

\section{JAKE}

- anything. Because I knew if I did, I'd be next. Or -

SUZIE

Fuck these guys.

JAKE

That's what I thought....that would be me. And I didn't do -

\section{SUZIE}

And that bastard of a sergeant is probably some major dude now. Still in the Force... Service. Pulling strings. Mouthing off about cultural change.

On screen JAKE breaks down. WAYNE pats JAKE on the back. The rest of the GROUP breaks into slow applause. 


\section{SUZIE}

Now, is that theatre or is that theatre? At its bloody best.

SUZIE pauses the image.

TED

What we know, Suzie, is that just like in the Defence Force, there's an attempt to change the culture.

\section{SUZIE}

But who's in charge? Huh? Now the bloody perpetrators are their superiors! By-stander guilt. They're riddled with it. Look.

SUZIE clicks the remote to play.

On screen we see TREVOR stand, look at the tears, the applause. TREVOR is disturbed. He exits frame.

Meanwhile SUZIE distracts TED with:

\section{SUZIE}

By-stander guilt. How does that impact on judgement? On self-respect over time? On commitment to the Police Service over time? I'm on to something, aren't I?

SUZIE turns the screen off.

\section{SUZIE}

I can't wait to publish. You know....I wouldn't be doing this, Ted, if I didn't believe in all the good that's coming out of it.

Lights down. TED exits.

CUT TO:

\section{INT.SUZIE'S OFFICE - DAY}

(A performed sequence with typed text)

SUZIE gathers her ideas.

As she speaks the screen behind her becomes a laptop screen; the words are typed in as she speaks them; the circle model appears, as she articulates its components. 


\section{SUZIE}

From the Indigenous perspective, the Indigenous world view, reference um t.b.a. we are a circle. There are segments: the physical, the spiritual, the emotional, the - physical, spiritual, emotional - the intellectual. Four segments. But I suggest in the modern world, in the Western way of being these segments are fragmented. So you get - intellectual, physical, spiritual and emotional - as separate circles. You get the fragmented self, find reference. But what connects all these circles - what brings them together is creativity. Creativity is the flow - it's how our dreams are realized. The pathway from our imagination to our newly realized selves. And the group the group reinforces this transition - just as the group can prevent it.

Yeah.

SUZIE exits through the door.

CUT TO:

\section{INT. SUZIE'S WORKSHOP - DAY}

(A filmed sequence)

The workshop screen fades up. TREVOR is visible as an observer.

C.U. MAXINE, she's waiting to begin the "Where am I?" exercise with JAKE.

$$
\text { SUZIE (V/O) }
$$

Day 5, Opt in/Opt out research study. The "where am I?" exercise, take 1.

Pause. JAKE watches MAXINE.

JAKE

Hear that?

$$
\text { SUZIE (V/O) }
$$

Maxine, you're supposed to start this impro. It's your call.

Pause.

\section{JAKE}

What do you reckon it is? That sound. 
Pause.

JAKE

I reckon it's an ibis.

C.U. MAXINE - we hear the sound of her heart beat.

\section{MAXINE}

It's not an ambulance, that's for sure.

\section{JAKE}

No, it's not -

\section{MAXINE}

If it was an ambulance, it'd be getting louder. I see her round now and then. That little girl. Unfortunately she had fourth degree burns to the top of her head, so she had no hair. She's fairly badly scarred; fingers pretty much gone and she'll probably spend the rest of her life getting different types of surgery, as she grows bigger. The skin obviously won't grow with it. Expand and keep going. It's obviously a day I'd like to forget.

The heartbeat stops.

Pause. EVERYONE waits.

SUZIE enters edge of frame.

\section{SUZIE}

Maxine.....there's something I'd like you to try -

\section{MAXINE}

(Furious) You - fucking - stupid, stuck-up - bitch!

MAXINE pushes her chair back and exits.

JAKE looks at SUZIE.

SUZIE remains motionless.

TREVOR stands.

Sound of heartbeat.

Screen fades to black. 
Heartbeat stops.

Stage lights up.

CUT TO:

\section{INT. TREVOR'S OFFICE - DAY}

(A performed sequence)

TREVOR enters UR.

SUZIE enters through the centre-stage door.

\section{TREVOR}

Helplessness sets up fight and flight and it can make people so anxious that they become neurotic. They have to marshal all of their day to day functions in a way to keep themselves safe. So for example they deal with their helplessness by confirming their sense of space again and again and again. So they're alike a person under siege. You know, you deepen the moat and you pull up the drawbridge and keep all the bastards out. But the fact that I'm in the castle keep on my own - I'm going to wear that and no-one's going to get me. But the problem is, of course, after a while, if you can't have relationships and you're emotionally on your own, people aren't going to wait around forever, so they're obviously going to want to undo that.

\section{SUZIE}

Lower the drawbridge.

\section{TREVOR}

Lower the drawbridge.

\section{SUZIE}

Through the imagination. Imagine, experience, perform, create.

\section{TREVOR}

That's a lot of lowering.

\section{SUZIE}

But you've seen my work. You've seen it happen. 


\section{TREVOR}

I've seen euphoria, yes. It's very entertaining.

SUZIE

So is creativity. Entertaining, inspiring. People becoming free to realize a new reality.

\section{TREVOR}

But what is it that we are seeing? Our eyes aren't neutral.

\section{SUZIE}

No. They're informed.

\section{TREVOR}

By what? Experience? Or ambition? What are we culturally, professionally impelled to recognize?

\section{SUZIE}

Are you saying I'm making it up?

\section{TREVOR}

I'm just questioning whether you're making it last.

\section{SUZIE}

And I question whether you want to see me fail. You don't like my getting results. You're disempowered by the group thing.

\section{TREVOR}

No. Not at -

\section{SUZIE}

Why did you send Maxine to me?

\section{TREVOR}

Maxine? She wanted to come.

\section{SUZIE}

To do your bidding, bust up the group, discredit me. Because my approach threatens you - paid by the hour year after year. 


\section{TREVOR}

Suzie, Maxine is a reality we share. Some proud young men and women carry more than their share of the highly dysfunctional elements of our society. Welcome to the world of the walking wounded. The seriously unwell. Welcome.

TREVOR exits.

SUZIE remains.

CUT TO:

\section{INT. TED'S OFFICE - DAY}

(A performed sequence)

TED enters.

TED

There's been a complaint. From your group.

\section{SUZIE}

Who?

TED

I can't say.

SUZIE

Loyalty to some loser rather than to me. Thanks heaps, Ted.

TED

Apparently the narratives are getting out of hand.

\section{SUZIE}

What, "truthful"?

Look, I'm not present. 


\section{SUZIE}

That's right. Ted, I'm not forcing them to do anything. They're loving it. They feel heard. Validated.

TED

Just take a step back here. You're working with a group of people, who are planning to leave the Police Force... ah, Service.

\section{SUZIE}

Yeah. And they're not going quietly. It's fantastic.

TED

The point is, Susie - the point is: they haven't left yet. They're undecided. You've chosen to examine a group of people, who say one thing but are still doing another.

\section{SUZIE}

"Have you ever considered leaving the Police F- Service?" That's all the survey asked. It's their stories, their emotions that have pushed the research.

\section{TED}

But it seems you're not taking account of indecision - and where that indecision can take them. The conflict that indecision sets up. You're not providing layers of safety.

\section{SUZIE}

It's okay. I'll blob the faces. Joke, Ted.

TED

Susie, look, I'm telling you, as your Supervisor, you have to stop.

SUZIE

Why?! Because of one complaint! Who was it? Trevor?

TED

Can’t say. 


\section{SUZIE}

Maxine. It was Maxine, wasn't it.

TED

No.

\section{SUZIE}

Bloody Maxine. Who did she get to contact you?

\section{TED}

The person involved came to me direct.

\section{SUZIE}

Doesn't that prove - (she has it in for me?)

TED

The point is we can deal with it now; we can't deal with it if it all blows up. You know, a lot of reputations are at stake. This is not just about your thesis.

\section{SUZIE}

Well, if it does blow up, doesn't it need to?

TED

Suzie! There's an ethics nightmare about to erupt. This is how crises begin... a murmur, a ripple becomes a contagion and no-one goes near the university for years. That's what happens. These are proud young men and women, who carry more than their share of the highly dysfunctional elements of our society.

\section{SUZIE}

I'll tell you what's beginning here. I'll tell you what's beginning. You've got a project up with the Police, haven't you? Something safe for the proud young men and women?

TED

No.

\section{SUZIE}

Really? 
TED

It's not confirmed.

SUZIE

It's not confirmed.

TED

It's a submission.

SUZIE

But they're keen.

TED

Interested.

SUZIE

And it's not about people, who want to leave, is it.

TED

No.

SUZIE

It's about - ? It's about -

TED

In-coming recruitment procedures. Addressing the culture at the coalface.

SUZIE

And where did that idea come from?

TED

Staff retention is a big issue. I mean ...It's what we've had to face in Education for years. We've got a lot to offer in this area. A lot of experience.

\section{SUZIE}

Oh, really? Not a lot of experience in dealing with after-hours incidents of excess alcohol and defecation. 
TED

You'd be surprised.

SUZIE

And you've used my work.

TED

Absolutely not!

SUZIE

What's the budget?

TED

It's a submission.

SUZIE

So it's big. The budget.

TED

It's - it would be good for the University. At this difficult time. Very good.

\section{SUZIE}

Oh, right. The University.

TED

Plus we're delivering the expertise, the investigative skills.

SUZIE

Why aren't I on it? Your research team.

TED

Look, the proposal is only short-listed. There isn't a team.

SUZIE

Yet.

TED

You've got your $\mathrm{PhD}$ to do. Go and play with people, who have already left. 


\section{SUZIE}

I'll stop doing what I'm doing. That's what you want, isn't it?

TED

Yes.

\section{SUZIE}

If I gave you my research - that would be of benefit, wouldn't it? The footage is - well, you've seen it. Deep insight into how the culture actually works to ah - subjugate, intimidate, humiliate, defeat. So it's a win-win. Win for you, Win for me.

TED

Your participants think what they've given you is exclusive to your study.

\section{SUZIE}

We could work around that.

\section{TED}

How's that?

\section{SUZIE}

We could persuade them to join yours - I mean, ours. We could say they have a new opportunity to address their concerns...

TED

To share their concerns....

\section{SUZIE}

To demonstrate their concerns....

\section{TED}

'Demonstrate'? Way too confrontational. The Police Service is trying to do the right thing....

\section{SUZIE}

Share their concerns then....

Stage lights fade down. 
TED exits.

SUZIE exits through the door.

CUT TO:

\section{INT. SUZIE'S WORKSHOP - DAY}

(A filmed sequence)

SUZIE'S shoulder is in frame.

The GROUP sits in a semi-circle facing us/ the camera.

MAXINE sits apart.

\section{SUZIE}

I know, I was disappointed, too, that we couldn't pursue this study. But! The fact that they have asked me to stop and instead instigated new recruitment procedures absolutely proves that they have known about the bullying culture all along.

The GROUP begins to put on stocking masks, turning their faces into blobs.

MAXINE doesn't move.

\section{SUZIE}

They want to resolve and harmonise the recruitment process. They want to resolve transparency issues and reconcile cultural misunderstandings. In short, they want to bring a culture of universal fulfilment into the workplace.

SUZIE exits frame. She goes behind the camera; the camera now focuses on specific faces, now that they are unrecognizable.

\section{SUZIE}

And I just want to encourage you all to consider joining this new "Culture at the Coalface" research initiative. It validates all the work we have already done together. And I want to congratulate you all for your courage, your determination and your resilience. Oh - and your acting! Fabulous work. Well done - all of you. I've learnt so much just watching you become so empowered. Maxine - ? Put the stocking on.

Fade to black. 


\section{INT. TED'S OFFICE - DAY}

(A performed sequence)

TED enters and sits at his desk.

SUZIE enters TED'S office through the centre door

\section{SUZIE}

Cheer up.

She's dead.

\section{SUZIE}

Who are we - ? Not Maxine....?

Pause....

TED

Maxine.

\section{SUZIE}

You're kidding me.

TED

Found her this morning. Just put the phone down. Hanged herself.

SUZIE

Where?

TED

Didn’t ask.

\section{SUZIE}

Oh My God.

TED

Sometime last night, they think. Early this morning. 


\section{SUZIE}

Was there a note?

TED

Saying - ?

\section{SUZIE}

Why she did it.

TED

From what you've told me, anyone in your seminar room would know why she did it.

\section{SUZIE}

I only said she was an obstructionist in a practical workshop flow sense. I never said she was suicidal.

Pause.

\section{SUZIE}

The point is: she was an outsider. Everyone else in my workshops went from strength to strength. Heaps of them said they'd be going into the new research project. Heaps.

TED

It only takes one outsider, Suzie. No-one will come near us for years.

\section{SUZIE}

No, no. She was way off the grid.

Says you.

\section{SUZIE}

I've got her on film.

No. No way. 


\section{SUZIE}

Think about how significant her story is. Her pain. On her face. Out there for everyone to see. Crying out in the dark.

TED

You're suggesting serious exploitation!

SUZIE

A case study.

TED

No!

SUZIE

Who knows she asked you to reprimand me or whatever?

TED

I know. You know.

\section{SUZIE}

You said she came to you direct.

TED

Yes.

SUZIE

No-one else?

TED

I - I don’t know.

\section{SUZIE}

She came to see you?

\section{TED}

She left a note in my pigeon hole.

\section{SUZIE}

You replied? 
TED

No.

SUZIE

Have you still got it? Maxine's note?

TED

Yes.

TED has the note.

\section{SUZIE}

Get rid of it.

TED hesitates.

SUZIE

I'll do it. I'll get rid of it.

SUZIE reaches out her hand.

TED

We're destroying evidence.

SUZIE

No, we're just making it worse for Trevor. She was his responsibility.

TED doesn't move.

\section{SUZIE}

This is "An Australian Story". Ted, it's for the greater good. C'mon, Ted. Dive in. Boots and all. What's the worst that can happen?

Freeze.

Sound of machine gun fire.

\section{END OF SCRIPT}




\section{Research statement}

\section{Research background}

This script springs from two experiences in the research field, when even adhering to the five guiding principles with in risk management template as articulated by Mienczakowski and Moore (2008: 456) the performed research ran the risk of being derailed by audience members. The first experience involved a relative of a deceased person, whose manner of death was talked about by the participants; the second experience involved a participant, who did not approve of the way a shared story was performed. Even with safeguards performed research is vulnerable. So this script imagines what might happen if ambition over-rides principles of practice and the only guideline is publication.

\section{Research contribution}

The aim of this script is promote discussion in academic circles in regard to the relationship between ethics, arts practice, protection and performance. In the two research projects mentioned above, ethics approval concerned data collection from individuals and individuals were protected. But performance continues to transform collective data, massing individuals' narratives and blurring the lines of individual story ownership (Madison 2005). Perhaps practitioners of performed research need to enter the field with more than ethics approval; perhaps they need a memorandum of understanding with participants clarifying that what they are contributing to is a collective story that belongs to the group but owned by the researcher.

\section{Research significance}

This script with its combination of stage and televised modes of story delivery experiments with character creation and authenticity. Ultimately using words, silence and body positioning, the aim is to use both performance mediums as vehicles for the expression of vulnerability and indecision in environments that demand confidence and consensus. It is hoped that the juxtaposition of these modes of story-telling create a greater understanding of the characters' dilemmas but a more objective appreciation of the worlds they are operating within.

\section{Works cited}

Adam-Smith, P 1979 The Anzacs Thomas Nelson Australia, West Melbourne

Day, S 2006 Personal communication (November 18)

Le Clezio, O 2014 Personal Communication (August 11)

Madison, D S 2005 'Staging fieldwork/performing human rights' in DS Madison \& JA Hamera (eds) The Sage handbook of performance studies Sage, Thousand Oaks, 397-417

Manera, B 2014 Personal communication (September 4)

Mienczakowsaki, J and T Moore 2008 'Performing data with notions of responsibility' in G Knowles \& A Cole (eds) Handbook of the arts in qualitative research Sage, Thousand Oaks, 451-59 
Wilkinson \& Anderson Artistry and academia

Nicholas, T 2008 Personal communication (February 16)

Young, W 2014 Personal communication (October 8) 